Prepared in cooperation with the Grand Valley Drainage District and the Colorado Water Conservation Board

\title{
Analysis of Escherichia coli, Total Recoverable Iron, and Dissolved Selenium Concentrations, Loading, and Identifying Data Gaps for Selected 303(d) Listed Streams, Grand Valley, Western Colorado, 1980-2018
}

Scientific Investigations Report 2021-5053

Version 1.1, September 2021 



\section{Analysis of Escherichia coli, Total Recoverable Iron, and Dissolved Selenium Concentrations, Loading, and Identifying Data Gaps for Selected 303(d) Listed Streams, Grand Valley, Western Colorado, 1980-2018}

By Lisa D. Miller, Rachel G. Gidley, Natalie K. Day, and Judith C. Thomas

Prepared in cooperation with the Grand Valley Drainage District and the Colorado Water Conservation Board

Scientific Investigations Report 2021-5053

Version 1.1, September 2021 


\section{U.S. Geological Survey, Reston, Virginia: 2021 \\ First release: 2021 \\ Revised: September 2021 (ver 1.1)}

For more information on the USGS - the Federal source for science about the Earth, its natural and living resources, natural hazards, and the environment-visit https://www.usgs.gov or call 1-888-ASK-USGS.

For an overview of USGS information products, including maps, imagery, and publications, visit https://store.usgs.gov/.

Any use of trade, firm, or product names is for descriptive purposes only and does not imply endorsement by the U.S. Government.

Although this information product, for the most part, is in the public domain, it also may contain copyrighted materials as noted in the text. Permission to reproduce copyrighted items must be secured from the copyright owner.

Suggested citation:

Miller, L.D., Gidley, R.G., Day, N.K., and Thomas, J.C., 2021, Analysis of Escherichia coli, total recoverable iron, and dissolved selenium concentrations, loading, and identifying data gaps for selected 303(d) listed streams, Grand Valley, western Colorado, 1980-2018 (ver. 1.1, September 2021): U.S. Geological Survey Scientific Investigations Report 2021-5053, 37 p., https://doi.org/10.3133/sir20215053.

Associated data for this publication:

Gidley, R.G., Miller, L.D., and Day, N.K., 2020, Analysis of Escherichia coli, total recoverable iron, and dissolved selenium concentrations and loads for selected 303(d) listed segments in the Grand Valley, western Colorado, 1991-2018 (ver. 3.0, August 2021): U.S. Geological Survey data release, https://doi.org/10.5066/P9P6WI44.

ISSN 2328-0328 (online) 


\section{Contents}

Abstract

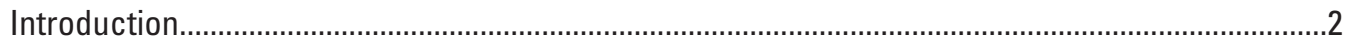

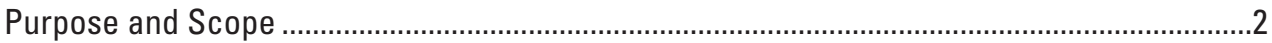

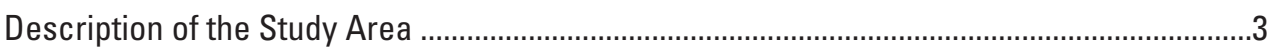

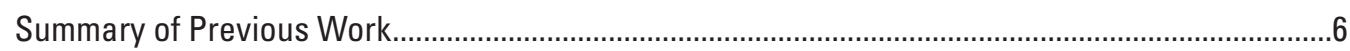

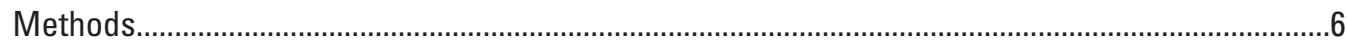

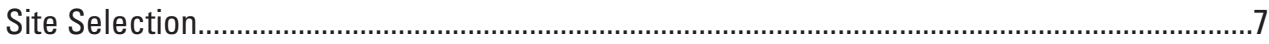

Data Acquisition and Quality Assurance and Control ..............................................................

Potential Selenium Bias.................................................................................................

Statistical Summary of Available Data .......................................................................................

Estimating Selenium Loads, 85th Percentile Concentrations, and Load Reductions................8

Estimating Loads Using an Annual Time Weighted Mean ................................................

Load Estimation Using Regression Analysis ......................................................................

Calculating the 85th Percentile of Selenium Concentrations.............................................9

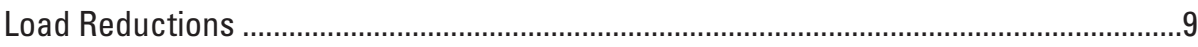

Selenium Concentration and Load Analysis at Main-Stem Sites ...........................................10

Flow Adjusted Trend Analysis.......................................................................................10

Trend Uncertainty Analysis ....................................................................................11

Regression Analysis Software ................................................................................11

Analysis of E. coli, Total Recoverable Iron, and Dissolved Selenium Concentrations and

Loading and Data Gaps ................................................................................................11

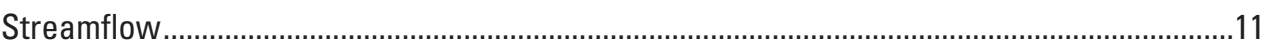

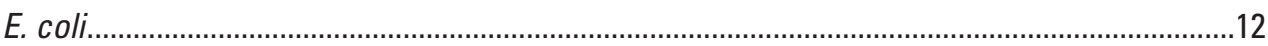

Adobe Creek E. coli Concentrations and Loads ..........................................................12

Leach Creek Escherichia coli Concentrations and Loads ............................................13

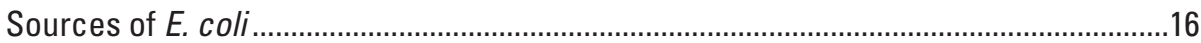

Total Recoverable Iron ............................................................................................................17

Dissolved Selenium Concentrations and Loads ...............................................................19

Tributary Dissolved Selenium Concentrations and Loads ..............................................20

Dissolved Selenium Concentrations and Instantaneous Loads at

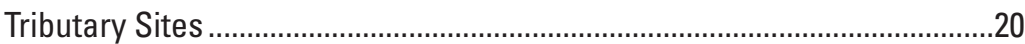

Annual Time-Weighted Mean Selenium Loading Analysis at Tributary Sites ........20

Adobe Creek at Mouth ...................................................................................20

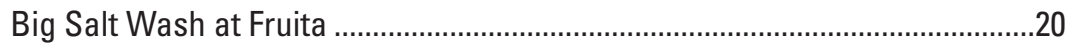

Leach Creek at Durham ................................................................................20

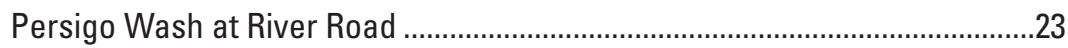

Reed Wash near Loma ..................................................................................2

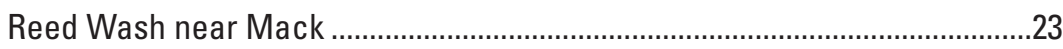

Salt Creek near Mack .......................................................................................23

Load Estimation Using Regression Analysis at Lewis Wash near Grand

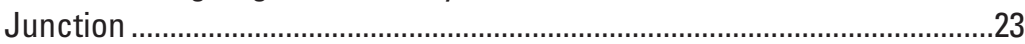

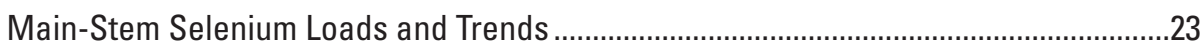

Dissolved Selenium Concentrations and Loads at Main-Stem Sites......................25 
Trend Analysis of Dissolved Selenium Concentrations and Loads at Main-Stem Sites. .25

Dissolved Selenium Load Contribution from the Grand Valley.................................25

Dissolved Selenium Loads and Data Gaps in the Grand Valley ......................................25

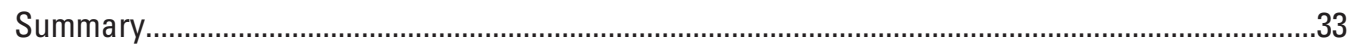

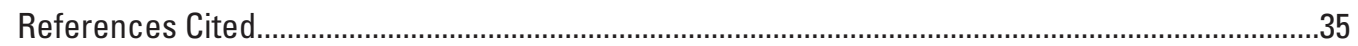

\section{Figures}

1. Map showing location of study area, sample sites, and 303(d) list segments, Colorado River Basin, western Colorado.

2. Graphs showing $A$, daily mean streamflow at select main-stem sites in the Grand Valley, Colorado; and $B$, difference in monthly mean streamflow between U.S. Geological streamflow-gaging stations, Colorado River near Colorado-Utah State Line and Colorado River near Cameo plus Gunnison River near Grand Junction, 2018

3. Map showing location of sample sites along Adobe Creek and Leach Creek

4. Graphs showing downstream profile of $A$, Escherichia coli concentrations;

$B$, instantaneous streamflow; and $C$, Escherichia coli loads along Adobe

Creek, 2016-17.

5. Graphs showing downstream profile downstream profile of $A$, Escherichia coli concentrations; $B$, instantaneous streamflow; and C, Escherichia coli loads along Leach Creek, 2016-17.

6. Graphs showing dissolved selenium concentrations, in micrograms per liter, for discrete water-quality samples at U.S. Geological streamflow-gaging stations $A$, Colorado River near Cameo; $B$, Gunnison River near Grand Junction; and $C$, Colorado River near Colorado-Utah State Line, for water years 1980-2018.

7. Graphs showing dissolved selenium loads, in pounds per day, for discrete water-quality samples at U.S. Geological streamflow-gaging stations $A$, Colorado River near Cameo; $B$, Gunnison River near Grand Junction; and $C$, Colorado River near Colorado-Utah State Line, for water years 1980-2018.

8. Graphs showing estimated annual mean and flow-normalized annual mean dissolved selenium concentrations and loads at U.S. Geological streamflow-gaging stations $A$ and $B$, Colorado River near Cameo; $C$ and $D$, Gunnison River near Grand Junction and; $E$ and $F$, Colorado River near Colorado-Utah State Line using weighted regressions on time, discharge, and season (WRTDS)

9. Graph showing estimated annual contribution of dissolved selenium load, in pounds per day, from the Grand Valley, western Colorado, for water years 2002-18 ....31

\section{Tables}

1. Site name, site number, site identifiers, 303(d) list segment (Colorado Department of Public Health and Environment, 2016), and latitude and longitude of water-quality sites, Grand Valley, western Colorado, 1993-2018.

2. Statistical summary of Escherichia coli concentration data for 303(d) listed segments (Colorado Department of Public Health and Environment, 2016) with limited datasets in the Grand Valley, western Colorado, 2005-17. 
3. Statistical summary of total recoverable iron concentration data for sites on 303(d) listed segments (Colorado Department of Public Health and Environment, 2016) with limited datasets in the Grand Valley, western Colorado, 1993-2018.

4. Statistical summary of dissolved selenium concentration data for tributary sites on 303(d) listed segments (Colorado Department of Public Health and Environment, 2016) with limited datasets in the Grand Valley, western Colorado, 1991-2018

5. Selenium loading analysis for sites on 303 (d) listed segments (Colorado Department of Public Health and Environment, 2016) using annual timeweighted mean (ATWM) method, Grand Valley, western Colorado .....

6. Summary of regression model diagnostics at Lewis Wash near Grand Junction, Grand Valley, western Colorado, water year 2003.

7. Selenium loading analyses for Lewis Wash near Grand Junction using regression analysis (R_LOADEST) method (Runkel and others, 2004), Grand Valley, western Colorado, 2003

8. Trends in annual and seasonal dissolved selenium concentrations and loads at selected main-stem U.S. Geological Survey streamflow-gaging stations, Grand Valley, western Colorado, water years 1980-2017.

9. Estimated annual dissolved selenium load, in pounds per year, calculated using weighted regressions on time, discharge, and season (WRTDS) at three main-stem U.S. Geological Survey streamflow-gaging stations bracketing the Grand Valley, western Colorado, for water years 2002-18.

10. Summary of values used to estimate a cumulative dissolved selenium load for tributaries to the Colorado River in the Grand Valley, western Colorado

\section{Conversion Factors}

U.S. Customary Units to International System of Units

\begin{tabular}{lcl}
\hline \multicolumn{1}{c}{ Multiply } & By & To obtain \\
\hline inch (in.) & Length & \\
foot (ft) & 2.54 & centimeter $(\mathrm{cm})$ \\
mile (mi) & 0.3048 & meter $(\mathrm{m})$ \\
\hline & 1.609 & kilometer $(\mathrm{km})$ \\
\hline acre & Area & \\
acre & 4,047 & square meter $\left(\mathrm{m}^{2}\right)$ \\
\hline & 0.4047 & hectare $(\mathrm{ha})$ \\
\hline cubic foot per second $\left(\mathrm{ft}^{3} / \mathrm{s}\right)$ & Flow rate & \\
\hline & 0.02832 & cubic meter per second $\left(\mathrm{m}^{3} / \mathrm{s}\right)$ \\
\hline pound, avoirdupois $(\mathrm{lb})$ & Mass & \\
pound per day $(\mathrm{lb} / \mathrm{d})$ & 0.4536 & kilogram $(\mathrm{kg})$ \\
pound per year $(\mathrm{lb} / \mathrm{yr})$ & 0.4536 & kilogram per day $(\mathrm{kg} / \mathrm{d})$ \\
\hline
\end{tabular}


International System of Units to U.S. Customary Units

\begin{tabular}{lcl}
\hline & Multiply & \multicolumn{1}{c}{ Bo obtain } \\
\hline \multicolumn{3}{c}{ Length } \\
\hline centimeter (cm) & 0.3937 & inch (in.) \\
\hline milliliter $(\mathrm{mL})$ & Volume & \\
milliliter $(\mathrm{mL})$ & 0.03381402 & ounce, fluid (fl. oz) \\
liter (L) & 0.00211338 & pint (pt) \\
liter (L) & 33.81402 & ounce, fluid (fl. oz) \\
liter (L) & 2.11338 & pint (pt) \\
liter (L) & 1.057 & quart (qt) \\
liter (L) & 0.2642 & gallon (gal) \\
& 61.02 & cubic inch (in $\left.{ }^{3}\right)$ \\
\hline gram (g) & Mass & \\
\hline
\end{tabular}

Temperature in degrees Celsius $\left({ }^{\circ} \mathrm{C}\right)$ may be converted to degrees Fahrenheit $\left({ }^{\circ} \mathrm{F}\right)$ as follows:

$$
{ }^{\circ} \mathrm{F}=\left(1.8 \times{ }^{\circ} \mathrm{C}\right)+32 .
$$

Temperature in degrees Fahrenheit $\left({ }^{\circ} \mathrm{F}\right)$ may be converted to degrees Celsius $\left({ }^{\circ} \mathrm{C}\right)$ as follows:

$$
{ }^{\circ} \mathrm{C}=\left({ }^{\circ} \mathrm{F}-32\right) / 1.8 \text {. }
$$

\section{Datum}

Vertical coordinate information is referenced to the North American Vertical Datum of 1988 (NAVD 88).

Horizontal coordinate information is referenced to the North American Datum of 1983 (NAD 83).

\section{Supplemental Information}

Concentrations of chemical constituents in water are given in either milligrams per liter $(\mathrm{mg} / \mathrm{L})$ or micrograms per liter $(\mu \mathrm{g} / \mathrm{L})$.

Water year is defined as the 12-month period from October 1 through September 30 and is designated by the year in which it ends.

Concentrations of Escherichia coli (E. coli) in water are reported as colony forming units per 100 milliliters (CFU/100 mL). 


\section{Abbreviations and Acronyms}

\begin{tabular}{|c|c|}
\hline AMLE & adjusted maximum likelihood estimation \\
\hline ATWM & annual time-weighted mean \\
\hline CDPHE & Colorado Department of Public Health and Environment \\
\hline CFU/100 mL & colony forming units per 100 milliliters \\
\hline E. coli & Escherichia coli \\
\hline EGRET & Exploration and Graphic for RivEr Trends \\
\hline EPA & U.S. Environmental Protection Agency \\
\hline FN & flow-normalized \\
\hline $\mathrm{ft}$ & foot \\
\hline giga-CFU/d & 1 billion colony forming units per day \\
\hline in & inch \\
\hline L & liter \\
\hline $\mathrm{lb} / \mathrm{d}$ & pounds per day \\
\hline $\mathrm{lb} / \mathrm{yr}$ & pounds per year \\
\hline$\mu g$ & microgram \\
\hline $\mathrm{mL}$ & milliliter \\
\hline MLE & maximum likelihood estimation \\
\hline MRL & method reporting limit \\
\hline NWIS & National Water Information System \\
\hline TMDL & total maximum daily load \\
\hline URL & upper reporting limit \\
\hline WOP & Water Quality Portal \\
\hline WOX & Water Quality Exchange \\
\hline WRTDS & Weighted Regressions on Time, Discharge, and Season \\
\hline WY & water year \\
\hline USGS & U.S. Geological Survey \\
\hline
\end{tabular}





\title{
Analysis of Escherichia coli, Total Recoverable Iron, and Dissolved Selenium Concentrations, Loading, and Identifying Data Gaps for Selected 303(d) Listed Streams, Grand Valley, Western Colorado, 1980-2018
}

\author{
By Lisa D. Miller, Rachel G. Gidley, Natalie K. Day, and Judith C. Thomas
}

\section{Abstract}

Tributaries to the Colorado River in the Grand Valley in western Colorado (segment COLCLC13b) have been placed on the State of Colorado 303(d) list as impaired for Escherichia coli (E. coli), total recoverable iron, and dissolved selenium. The Colorado Department of Public Health and Environment Water Quality Control Division is required to develop total maximum daily loads for these constituents in these tributaries. The U.S. Geological Survey, in cooperation with the Grand Valley Drainage District and Colorado Water Conservation Board, conducted a study to (1) characterize concentrations, loads, and load reductions for E. coli, total recoverable iron, and dissolved selenium using existing data and (2) identify water-quality data gaps to inform future monitoring strategies. This study analyzed water-quality and streamflow data for 3 main-stem sites (2 sites along the Colorado River and 1 site along the Gunnison River) and 29 selected sites on tributaries to the Colorado River.

Sample data were available at five sites along Adobe Creek and at six sites along Leach Creek, the two tributaries in the study area that are impaired for E. coli. All geometric mean E. coli concentrations at sites along Adobe Creek and Leach Creek exceeded the State recreational use standard of 126 colony forming units per 100 milliliters (CFU/100 mL). In Adobe Creek, E. coli concentrations in samples ranged from 45.7 to more than 2,420 CFU/100 mL (method upper reporting limit for undiluted samples), and geometric mean concentrations at sites ranged from 301 to $1,180 \mathrm{CFU} / 100 \mathrm{~mL}$. The $E$. coli concentrations generally increased in the downstream direction in Adobe Creek; however, increases were not seen between all sites. The largest downstream increase in $E$. coli concentration was measured between the two most upstream sites. In Leach Creek, concentrations of $E$. coli in samples ranged from 25.9 to more than 2,420 CFU/100 mL, and geometric mean concentrations at sites ranged from 160 to $259 \mathrm{CFU} / 100 \mathrm{~mL}$. The $E$. coli concentrations showed no consistent downgradient increase in Leach Creek. In fact, some of the highest $E$. coli concentrations were measured at the most upstream site, Leach Creek at Summer Hill Drive.
Total recoverable iron concentrations and loads were evaluated at 15 tributary sites for samples collected from August 1993 to February 2018. Median total recoverable iron concentrations ranged from 211 to 4,670 micrograms per liter $(\mu \mathrm{g} / \mathrm{L})$. The chronic aquatic-life water-quality standard $(1,000 \mu \mathrm{g} / \mathrm{L})$ was exceeded in most irrigation season (April through October) samples but was rarely exceeded in nonirrigation season (November through March) samples. Concentrations were often an order of magnitude higher in samples collected during irrigation season than in samples collected during nonirrigation season. None of the sites had enough concurrent total recoverable iron and streamflow data to compute annual loads. As with E. coli, the lack of concurrent total recoverable iron and streamflow information represents a data gap, which needs to be addressed to compute annual loads.

Dissolved selenium concentrations and loads were evaluated at 20 tributary sites using discrete water-quality data collected 1991-2018. Dissolved selenium concentrations were higher during nonirrigation season than during irrigation season at tributary sites. However, irrigation season dissolved selenium loads were generally higher than nonirrigation selenium loads, because streamflows were higher during irrigation season. Regression analysis was used to estimate daily dissolved selenium concentrations and loads at three main-stem sites for water years (WYs) 1980-2018 (Gunnison River near Grand Junction and Colorado River near Colorado-Utah State Line) and WYs 2002-18 (Colorado River near Cameo). A trend analysis of dissolved selenium concentrations and loads was completed for these sites from the same respective starting dates but ending in 2017. A continuing downward trend in dissolved selenium concentration was observed at all sites and across all seasonal designations of the analysis. The dissolved selenium concentration decreased by $0.12 \mu \mathrm{g} / \mathrm{L}$ from WY 2002 to 2017 at Colorado River near Cameo, representing an 18-percent decrease during the time period. The dissolved selenium concentration at Gunnison River near Grand Junction decreased by $4.2 \mu \mathrm{g} / \mathrm{L}$ from WY 1980 to 2017, representing a 56-percent decrease overall. During the same time period, dissolved selenium concentration at Colorado River near Colorado-Utah State Line decreased by $3.8 \mu \mathrm{g} / \mathrm{L}$, representing a 56-percent decrease 
overall. A downward trend in dissolved selenium load was also observed at all sites and across all seasonal designations of the analysis. The relative contribution of dissolved selenium from the Grand Valley near Grand Junction was estimated by comparing loads at main-stem sites bracketing the study area. The two upstream sites, Colorado River near Cameo and Gunnison River near Grand Junction, contributed 60,300 cumulative pounds and 251,000 cumulative pounds, respectively, during WYs 2002-18. At the furthest downstream site, Colorado River near ColoradoUtah State Line, 490,000 cumulative pounds were estimated during the same time period, indicating that the region between Whitewater and State line contributed approximately 179,000 cumulative pounds or a mean annual load of $10,500 \mathrm{lb} / \mathrm{yr}$. Grand Valley dissolved selenium contributions appear to be stable during WYs 2002-18.

\section{Introduction}

In 2002, it was estimated that more than 218 million people live within 10 miles of a river, lake, or estuary that is considered impaired according to the U.S. Environmental Protection Agency (EPA) (Shipp and Cordy, 2002). The leading causes for impairment are excess sediment, nutrients (nitrogen and phosphorus), trace elements (selenium, iron, and others), and pathogenic microorganisms such as Escherichia coli (E. coli) (Shipp and Cordy, 2002). Under the Clean Water Act, Section 303(d), States are required to submit their list of impaired streams to the EPA for approval every two years. For each water body on the list, the State must identify the affected use, the constituent(s) causing the impairment, and assign priorities for the development of total maximum daily loads (TMDLs) based on the severity of the impairment and the sensitivity of the designated use. "A TMDL establishes the maximum amount of a pollutant allowed in a waterbody and serves as the starting point or planning tool for restoring water quality," (EPA, 2020). Loads are measured in mass-time units such as pounds per day. The term "TMDL" also refers to the process used to determine allowable contaminant loads in streams. The Colorado Department of Public Health and Environment (CDPHE) has divided most of the water bodies in the State into management units called segments. A segment is a water body or portion thereof used for, among other things, the assessment of instream water quality and the development of TMDLs (CDPHE, 2020). Segments can be further divided into subsections to better target specific contaminants and uses. The U.S. Geological Survey (USGS) in cooperation with States, Territories, and authorized Tribes often assists in the TMDL process by collecting, managing, and interpreting data (Shipp and Cordy, 2002). In the Colorado River Basin, the USGS has analyzed selenium loads in the lower Gunnison River Basin to aid in the development of a TMDL (Thomas and others, 2008).

The State of Colorado has determined that dissolved selenium, total recoverable iron, excess sediment, and E. coli have impaired segment COLCLC13b for aquatic life and recreational use, and the segment has been placed on the State's 303(d) list. Stream segment COLCLC13b includes all tributaries to the Colorado River from the Government Highline Canal diversion on the Colorado River to Salt Creek as shown in figure 1 and does not include the main stem Colorado River (CDPHE, 2016).

A study was conducted by the USGS, in cooperation with the Grand Valley Drainage District and Colorado Water Conservation Board to (1) characterize concentrations, stream loading, and load reductions for E. coli, total recoverable iron, and dissolved selenium using existing data collected from 1980 through 2018 and (2) identify water-quality data gaps to provide information for future monitoring strategies. This study increases understanding of the historical water quality of the tributaries to the Colorado River in Grand Valley, Colo., and the relations between streamflow, constituent concentrations, and calculated loads over time. The results also will assist the local water community with a better understanding of stream impairment in the selected stream segments and can be used to inform the TMDL process to better manage affected segments. In this study, selected tributaries in subsections COLCLC13b_A, COLCLC13b_B, and COLCLC13b_C were examined for impairment by dissolved selenium and total recoverable iron in Grand Valley, Colo. In addition, subsection COLCLC13b_C (Adobe Creek and Leach Creek) was examined for impairment by E. coli (CDPHE, 2016).

\section{Purpose and Scope}

This report provides information on E. coli, total recoverable iron, and dissolved selenium concentrations and loads for data collected from 1980-2018 for tributaries to the Colorado River at 29 sample sites in stream subsections COLCLC13b_A, COLCLC13b_B, and COLCLC13b_C, as well as two USGS streamflow-gaging stations on the Colorado River: Colorado River near Cameo, Colo. (USGS 09095500), and Colorado River near Colorado-Utah State Line, Colo. (USGS 09163500), and one USGS streamflow-gaging station on the Gunnison River, Gunnison River near Grand Junction, Colo. (USGS 09152500) (fig. 1, table 1). Further, this report discusses the dissolved selenium load reductions needed to meet water-quality standards at sites with adequate data to compute loads and describes data gaps where additional data could improve load estimates and better inform future monitoring strategies. Statistical summaries were calculated for sites with $E$. coli and total recoverable iron data and sites with dissolved selenium data that did not have enough paired concentration and streamflow data to estimate an annual dissolved selenium load. Because limited streamflow data were concurrent with E. coli and total recoverable iron concentrations, only instantaneous loads were computed for these constituents. For sites with adequately paired dissolved selenium concentration and streamflow data, mean daily, annual, irrigation season, and nonirrigation season mean dissolved selenium loads were computed. Also, an assessment of potential laboratory bias was completed for the selenium data used in the analysis. 


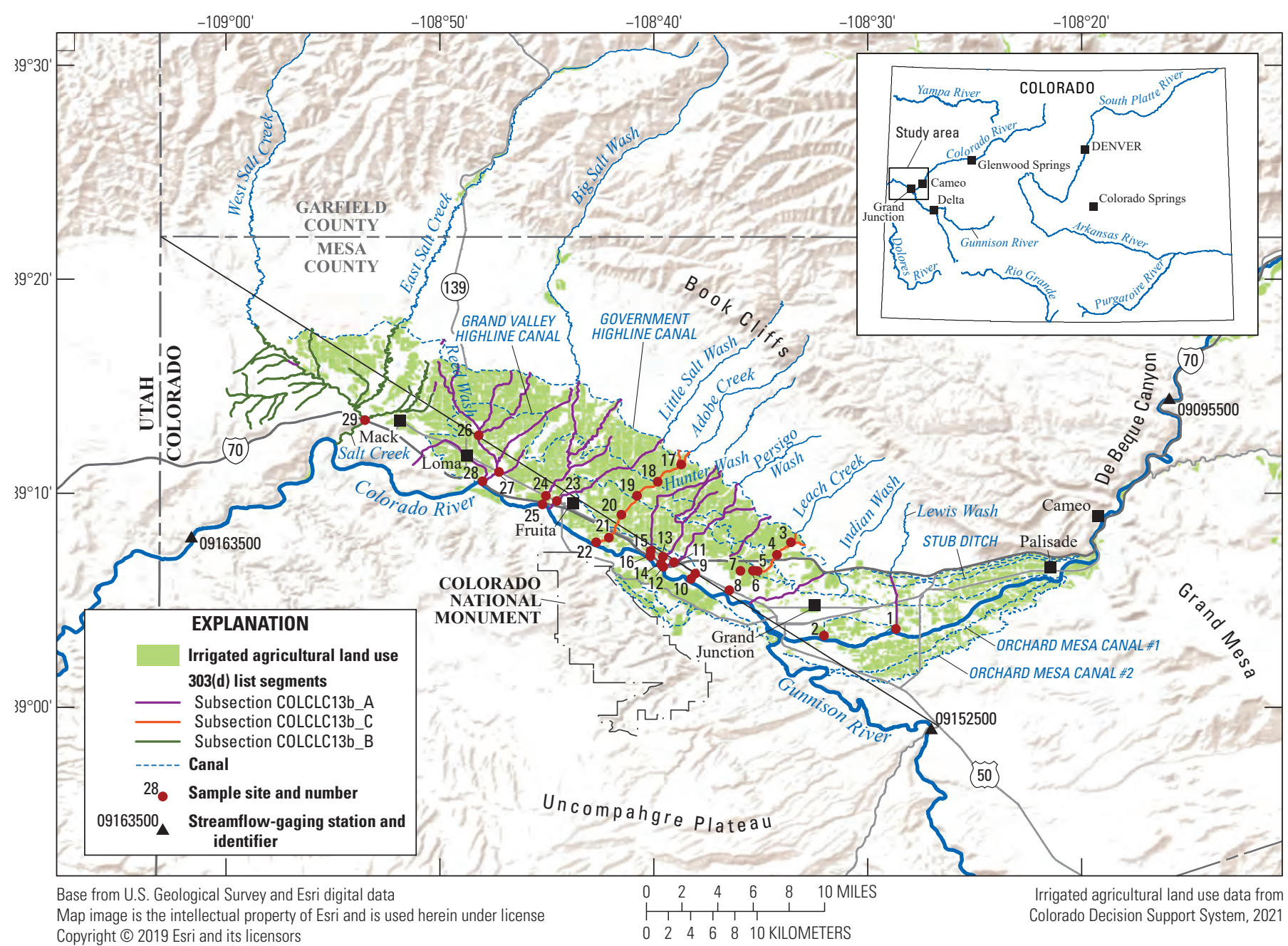

Copyright (c) 2019 Esri and its licensors

$\begin{array}{llllll}0 & 2 & 4 & 6 & 8 & 10 \\ 0 \text { KILOMETERS }\end{array}$

All rights reserved

Geographic projection, decimal degrees, meters

North American Datum 1983

Figure 1. Location of study area, sample sites, and 303(d) list segments, Colorado River Basin, western Colorado.

\section{Description of the Study Area}

The Grand Valley is approximately 30 miles long and 5 miles wide and is located along the Colorado River in Mesa and Garfield Counties, Colo. (fig. 1). The valley begins at De Beque Canyon 5 miles east of Palisade, Colo., and continues west-northwest toward the Colorado-Utah State line. The valley is bounded by the Book Cliffs to the north, Grand Mesa to the southeast, and the Uncompahgre Plateau to the south. The Colorado National Monument, a National Park Service unit, is on the southwest side of the valley west of Grand Junction, Colo. (fig. 1). Much of the land surrounding the Grand Valley is publicly owned and managed by the Bureau of Land Management.

Grand Valley land-surface elevation decreases from east to west between Palisade, Colo., at 4,728 feet (ft) and Mack, Colo., at 4,521 ft (MAPLOGS.COM, 2021). The valley was formed as material to the northeast eroded, leaving a relatively flat valley that gradually slopes upward toward the northeast (Butler and others, 1996). Numerous small streams and washes dissect the valley and discharge into the Colorado River. The northern part of the valley consists of interbedded light gray sandstone and gray shales of Upper Cretaceous age. This material overlies Cretaceous-age marine shales and mudrocks containing high levels of selenium and other constituents (Seiler and others, 2003). Deep percolation of irrigation water can mobilize these materials and thus introduce them into the hydrologic cycle (Mayo, 2008). Alluvium in the valley consists of residuum from both Upper Cretaceous and Cretaceous deposits (Butler and others, 1996).

Farming began in the Grand Valley near the end of the 19th century with the introduction of grains and fruit. However, irrigation was not brought to the valley until 1918 with the completion of the Government Highline Canal, a feature of the Bureau of Reclamation Grand Valley Project, which created 50,000 acres of arable land. Today, the primary crops grown in the area are corn, alfalfa, wheat, beans, peaches, and grapes. The area also supports a livestock industry (Simonds, 1994). 
Table 1. Site name, site number, site identifiers, 303(d) list segment (Colorado Department of Public Health and Environment, 2016), and latitude and longitude of water-quality sites, Grand Valley, western Colorado, 1993-2018.

[USGS, U.S. Geological Survey]

\begin{tabular}{|c|c|c|c|c|c|}
\hline $\begin{array}{c}\text { Site } \\
\text { name }\end{array}$ & $\begin{array}{l}\text { Site number } \\
\text { (fig. 1) }\end{array}$ & $\begin{array}{c}\text { Site } \\
\text { identifier(s) }\end{array}$ & $\begin{array}{l}\text { 303(d) } \\
\text { list segment }\end{array}$ & $\begin{array}{c}\text { Latitude } \\
\text { (in decimal degrees) }\end{array}$ & $\begin{array}{c}\text { Longitude } \\
\text { (in decimal degrees) }\end{array}$ \\
\hline Colorado River near Cameo & 09095500 & ${ }^{1}$ USGS-09095500 & COLCLC02a_A & 39.23917 & -108.2656 \\
\hline Gunnison River near Grand Junction & 09152500 & ${ }^{1}$ USGS-09152500 & COGULG02_A & 38.98333 & -108.4500 \\
\hline Lewis Wash near Grand Junction & 1 & $\begin{array}{l}\text { 2USGS-09106200, 21COL001_WQX-TMDL-LC09, } \\
\text { CORIVWCH_WQX-4064 }\end{array}$ & COLCLC13b_A & 39.06054 & -108.4779 \\
\hline Indian Wash at C $1 / 2$ Road & 2 & $\begin{array}{l}\text { USGS-390320108315901, 21COL001_WQX- } \\
\text { 11135B }\end{array}$ & COLCLC13b_A & 39.05554 & -108.5337 \\
\hline Appleton Drain at River Road & 9 & $\begin{array}{l}\text { USGS-390613108380101, 21COL001_WQX- } \\
\text { TMDL-ADT2 }\end{array}$ & Not on 303(d) list & 39.10359 & -108.6343 \\
\hline $\begin{array}{l}\text { Appleton Drain upstream from } \\
\text { Colorado River }\end{array}$ & 10 & 21COL001_WQX-TMDL-ADT & Not on 303(d) list & 39.09976 & -108.6378 \\
\hline Leach Creek at Summer Hill Drive & 3 & 21COL001_WQX-TMDL-LC6 & COLCLC13b_C & 39.12809 & -108.5598 \\
\hline Leach Creek at 26 Road & 4 & 21COL001_WQX-TMDL-LC5 & COLCLC13b_C & 39.11837 & -108.5708 \\
\hline $\begin{array}{l}\text { Leach Creek upstream from Grand } \\
\text { Valley Canal }\end{array}$ & 5 & 21COL001_WQX-TMDL-LC4 & COLCLC13b_C & 39.10583 & -108.5858 \\
\hline $\begin{array}{l}\text { Leach Creek at G Road and } 25 \text { Road } \\
\text { upstream side of turnabout }\end{array}$ & 6 & 21COL001_WQX-TMDL-LC3 & COLCLC13b_C & 39.10614 & -108.5893 \\
\hline $\begin{array}{l}\text { Leach Creek at G Road and } 24.5 \text { Road } \\
\text { downstream side of turnabout }\end{array}$ & 7 & 21COL001_WQX-TMDL-LC2 & COLCLC13b_C & 39.10614 & -108.5991 \\
\hline Leach Creek at Durham & 8 & $\begin{array}{l}\text { 2USGS-09152650, 21COL001-11135, } \\
\text { 21COL001_WQX-11135, 21COL001_WQX- } \\
\text { TMDL-LC1 }\end{array}$ & COLCLC13b_C & 39.09081 & -108.6076 \\
\hline Persigo Wash at River Road & 11 & USGS-390645108390101 & COLCLC13b_A & 39.11248 & -108.6509 \\
\hline Persigo Wash at mouth near Fruita & 12 & $\begin{array}{l}\text { 21COL001_WQX-TMDL-LC15, 21COL001_WQX- } \\
\text { TMDL-PSWT, USGS-390633108393100 }\end{array}$ & COLCLC13b_A & 39.10906 & -108.6592 \\
\hline Pritchard Wash at River Road & 13 & USGS-390700108393101 & COLCLC13b_A & 39.11665 & -108.6593 \\
\hline $\begin{array}{l}\text { Pritchard Tributary upstream from } \\
\text { Colorado River }\end{array}$ & 14 & 21COL001_WQX-TMDL-PRT & COLCLC13b_A & 39.11113 & -108.6609 \\
\hline Hunter Wash at River Road & 15 & CORIVWCH_WQX-4063, USGS-390717108400501 & COLCLC13b_A & 39.12137 & -108.6687 \\
\hline $\begin{array}{l}\text { Hunter Wash upstream from Colorado } \\
\text { River }\end{array}$ & 16 & 21COL001_WQX-TMDL-HWT & COLCLC13b_A & 39.11731 & -108.6690 \\
\hline Adobe Creek at 22 Road & 17 & 21COL001_WQX-TMDL-AC5 & COLCLC13b_C & 39.18879 & -108.6450 \\
\hline $\begin{array}{l}\text { Adobe Creek upstream from Highline } \\
\text { Canal at } 21 \text { Road }\end{array}$ & 18 & 21COL001_WQX-TMDL-AC4 & COLCLC13b_C & 39.17534 & -108.6638 \\
\hline
\end{tabular}


Table 1. Site name, site number, site identifiers, 303(d) list segment (Colorado Department of Public Health and Environment, 2016), and latitude and longitude of water-quality sites, Grand Valley, western Colorado, 1993-2018.-Continued

[USGS, U.S. Geological Survey]

\begin{tabular}{|c|c|c|c|c|c|}
\hline $\begin{array}{c}\text { Site } \\
\text { name }\end{array}$ & $\begin{array}{l}\text { Site number } \\
\text { (fig. 1) }\end{array}$ & $\begin{array}{c}\text { Site } \\
\text { identifier(s) }\end{array}$ & $\begin{array}{l}303(d) \\
\text { list segment }\end{array}$ & $\begin{array}{c}\text { Latitude } \\
\text { (in decimal degrees) }\end{array}$ & $\begin{array}{c}\text { Longitude } \\
\text { (in decimal degrees) }\end{array}$ \\
\hline Adobe Creek at K Road & 19 & 21COL001_WQX-TMDL-AC3 & COLCLC13b_C & 39.16451 & -108.6798 \\
\hline Adobe Creek at J and 19.5 Road & 20 & 21COL001_WQX-TMDL-AC2 & COLCLC13b_C & 39.14962 & -108.6917 \\
\hline Adobe Creek near mouth at 19 Road & 21 & $\begin{array}{l}\text { 21COL001_WQX-11133, 21COL001-11133, } \\
\text { 21COL001_WQX-TMDL-AC1, } \\
\text { 21COL001_WQX-TMDL-LC16, } \\
\text { USGS-390755108420200 }\end{array}$ & COLCLC13b_C & 39.13184 & -108.7015 \\
\hline $\begin{array}{l}\text { Adobe Creek at mouth, Adobe Creek } \\
\text { near Fruita }\end{array}$ & 22 & USGS-390741108424301, ${ }^{2}$ USGS-09152900 & COLCLC13b_C & 39.12823 & -108.7116 \\
\hline $\begin{array}{l}\text { Little Salt Wash at Highway } 50 \text { at } \\
\text { Fruita }\end{array}$ & 23 & $\begin{array}{l}\text { 21COL001_WQX-TMDL-LSWT, } \\
\text { 21COL001_WQX-TMDL-LSWT2, } \\
\text { USGS-390938108443101 }\end{array}$ & COLCLC13b_A & 39.16054 & -108.7426 \\
\hline Big Salt Wash at Fruita & 24 & $\begin{array}{l}\text { 2USGS-09153270, CORIVWCH_WQX-4061, } \\
\text { 21COL001_WQX-TMDL-BSWT2 }\end{array}$ & COLCLC13b_A & 39.16359 & -108.7509 \\
\hline Big Salt Wash downstream from I-70 & 25 & $\begin{array}{l}\text { CORIVWCH_WQX-3263, 21COL001_WQX- } \\
\text { TMDL-BSWT }\end{array}$ & COLCLC13b_A & 39.15887 & -108.7533 \\
\hline Reed Wash near Mack & 26 & ${ }^{2}$ USGS-09153290 & COLCLC13b_A & 39.21137 & -108.8037 \\
\hline Reed Wash near Loma & 27 & $\begin{array}{l}\text { 2USGS-09153300, 21COL001_WQX-TMDL-RWT, } \\
\text { 21COL001_WQX-TMDL-LC22 }\end{array}$ & COLCLC13b_A & 39.18359 & -108.7873 \\
\hline Reed Wash near Fruita & 28 & $\begin{array}{l}\text { 21COL001_WQX-TMDL-RWT1, } \\
\text { CORIVWCH_WQX-4073, } \\
\text { USGS-391029108480200 }\end{array}$ & COLCLC13b_A & 39.17576 & -108.8004 \\
\hline Salt Creek near Mack & 29 & $\begin{array}{l}\text { 2USGS-09163490, 21COL001-11130, } \\
\text { 21COL001_WQX-TMDL- } \\
\text { SCT, USGS-391318108533201, } \\
\text { USGS-391320108532801 }\end{array}$ & COLCLC13b_B & 39.22220 & -108.8918 \\
\hline $\begin{array}{l}\text { Colorado River near Colorado-Utah } \\
\text { State Line }\end{array}$ & 09163500 & ${ }^{1}$ USGS-09163500 & COLCLC03_A & 39.13278 & -109.0264 \\
\hline
\end{tabular}

${ }^{1}$ Active (2020) USGS continuous-record streamflow-gaging station.

${ }^{2}$ Historical USGS continuous-record streamflow-gaging station. 
Most of the streamflow in tributaries in the Grand Valley is irrigation water, and most of the tributaries are ephemeral upgradient from the Government Highline Canal. Streamflow increases substantially during irrigation season and decreases during nonirrigation season (Leib, 2008). The irrigation season typically occurs from April through October. The remaining portion of the year (November through March) is the nonirrigation season (no irrigation water is delivered).

According to the Köppen classification system, the Grand Valley has a tropical and subtropical steppe climate (Köppen, 1918). Between 1981 and 2010, the normal annual precipitation (including snow) was 9.42 inches (in.). Monthly normal minimum, mean, and maximum temperatures were 39.7, 52.6, and 65.6 degrees Fahrenheit, respectively (National Oceanic and Atmospheric Administration, National Centers for Environmental Information, 2019).

\section{Summary of Previous Work}

Considerable work has been done in the Grand Valley to understand the fate and transport of dissolved solids (salinity) and trace elements, primarily selenium, in all waters discharging into the Colorado River as well as in the Colorado River itself. Shamberger (1981) stated that selenium is one of the most widely distributed elements in the Earth's crust and is found in soils underlain by selenium-rich parent material. Meteoric water, groundwater, and water used to irrigate these soils mobilizes selenium into the hydrologic cycle and ecosystems, negatively affecting the biota. Lin and others (2002) showed that agriculture in semiarid climates requires intensive irrigation and subsurface drainage to prevent salt accumulation in soils. Their study, at sites in central California, showed that effluent from tile drains could contain up to 500 micrograms per liter $(\mu \mathrm{g} / \mathrm{L})$ of selenium over background levels of $2 \mu \mathrm{g} / \mathrm{L}$. Where left unmanaged, selenium-rich evaporite deposits can reach toxic levels. Seiler and others (2003), in their study of irrigation-induced contamination of water, sediment, and biota in the Western United States, concluded that selenium was the trace element in surface water that most commonly exceeded the chronic aquatic-life-exposure criteria of $4.6 \mu \mathrm{g} / \mathrm{L}$ (CDPHE, 2020). This study also identified predictive tools to aid managers in identifying specific land areas at risk for irrigation-induced selenium contamination. These tools range from identifying broad geographic regions where selenium contamination is likely, to assessing the probability that selenium concentrations in a specific stream or lake may exceed the criterion for chronic exposure to selenium.

To determine the effects of irrigation water management on the quality of farm-field runoff and to reduce salt loads in the Colorado River in the Grand Valley, Duke and others (1976) examined the variables needed to predict the effects of deep-water percolation, tail-water runoff, and lateral seepage on the quality and quantity of return flows to the Colorado River. The study concluded that salt loads associated with irrigation return flows could be reduced with more uniform irrigation applications, thus reducing return flows to the Colorado River. In a 2008 study of land use and the effects on deep percolation (12 in. or more) of irrigation water in the Grand Valley, Mayo (2008) concluded that converting irrigated agricultural land to urban residential land not only resulted in substantially lower demand for irrigation water in urban and residential areas but also reduced the amount of deep percolation water, thus lowering groundwater return flows and salt delivery per developed acre. Similarly, Richards and Moore (2015) found statistically significant decreases in salinity and dissolved selenium loading following conversion from irrigated agricultural land use to urban land use in a subbasin in Montrose Arroyo.

In a study of selenium loads in the Grand Valley, Leib (2008) examined three subbasins of the Colorado River Basin: Lewis Wash, Persigo Wash, and Adobe Creek. Each basin represented a different land use: Lewis Wash, residential; Persigo Wash, transition from agricultural to residential; and Adobe Creek, agricultural. In Lewis Wash, selenium concentrations and loads generally increased in the downstream direction. In Persigo Wash, selenium concentrations generally decreased or remained constant in a downstream direction, whereas selenium loads increased. In Adobe Creek, concentrations and loads of selenium generally increased in the downstream direction.

A subsequent report by Mayo and Leib (2012) presented results from an evaluation of trends in selenium loads and concentrations for two USGS streamflow-gaging stations: Gunnison River near Grand Junction (USGS 09152500) and Colorado River near Colorado-Utah State Line (USGS 09163500). Flow-adjusted selenium loads were estimated for water years (WY) 1986 and 2008. Water year is defined as the 12 -month period from October 1 through September 30 and is designated by the year in which it ends. The annual selenium load for the Gunnison River site was estimated to be 23,200 pounds for WY 1986 and 16,600 pounds for WY 2008, a 28.6-percent decrease. Annual selenium load for the Colorado River site was estimated to be 56,600 pounds for WY 1986 and 34,300 pounds for WY 2008, a 39.3-percent decrease.

\section{Methods}

Site selection and subsequent data analysis were performed using available information. Coincident samples (differing site identifiers from different data sources but with similar location) were combined to provide a larger sample population from which loads and load reductions could be calculated. All data used in this study were analyzed in laboratories using EPA approved methodologies and data-handling practices. Site-selection protocols that incorporated the maximum amount of pertinent data were used, as well as analytical methods that were appropriate for the type and density of the data acquired. 


\section{Site Selection}

Sites throughout the Grand Valley were screened such that samples collected at each site would include data for streamflow, E. coli, dissolved selenium, and total recoverable iron. To be considered for analysis, an ideal site would need to have been sampled at least four times per year (to represent seasonal changes) for the past five years and have concurrent streamflow measurements for all samples. Not all samples from all sites fit these criteria; thus, all samples (regardless of sample date) with data for E. coli, total recoverable iron, and dissolved selenium were considered. For stream segments impaired for total recoverable iron and dissolved selenium, sites were selected that represent the cumulative contribution of these constituents to the 303(d) list segments. Sites that represent the cumulative contribution are typically sites that are located at or close to the mouth of a segment. Where data were available along a segment, a concentration or load profile was produced. This profile helped identify sites where concentrations or loads increased or decreased.

\section{Data Acquisition and Quality Assurance and Control}

Water-quality and streamflow data for 3 USGS streamflow-gaging stations-Colorado River near Cameo (USGS 09095500), Colorado River near Colorado-Utah State Line (USGS 09163500), and Gunnison River near Grand Junction (USGS 09152500); and 29 selected sites on tributaries to the Colorado River in Grand Valley were retrieved from the Water-Quality Portal (WQP; National Water Quality Monitoring Council, 2019; https://www.waterqualitydata.us/). Data presented in this report were summarized by Gidley and others (2020). The WQP provides access to the USGS National Water Information System (NWIS) database (https://doi.org/10.5066/F7P55KJN) as well as data submitted through the EPA Water Quality Exchange (WQX; https:/www.epa.gov/waterdata/water-quality-data-wqx). The WQX is a framework that allows States, Tribes, and other data partners to submit and share water-quality monitoring data from the web to the WQP. All data retrieved through the WQP are subject to the quality assurance and control plans of the collection entity as well as those associated with the analytical methods used. For this study, additional procedures were used to ensure data quality. These procedures included screening for errors by comparing selected values to typical ranges of values for constituents in natural waters (Hem, 1985). Spatial comparisons of site locations were made as well to determine if water-quality samples were coincidental but with different site identifiers. Each of these occurrences were evaluated and, when appropriate, combined under a single site identifier.

All E. coli samples were analyzed using EPA method 9223-B (American Public Health Association and others, 2018). This method uses IDEXX Corporation's "Colilert Quanti-tray" technique, a colorimetric method that produces a most probable value for each sample. One most probable value is equivalent to one colony forming unit (CFU) (Leonard, 2020). For undiluted samples, the upper reporting limit (URL) for method 9333-B is 2,420 colony forming units per 100 milliliters (CFU/100 mL). Samples with concentrations known or suspected to be near the URL are diluted and quantified accordingly; however, E. coli concentrations can vary substantially at a given site, and it may not be possible to approximate a concentration prior to analysis. A total of $19 \mathrm{E}$. coli samples, collected at four sites on Adobe Creek and one site on Leach Creek, were qualified by the CDPHE as having E. coli concentrations greater than the URL. For the purposes of this report, all E. coli values reported as greater than the URL were assumed to have not been diluted and were assigned a value of 2,420 CFU per 100 milliliters (CFU/100 mL).

\section{Potential Selenium Bias}

The USGS National Water Quality Laboratory issued a memorandum to alert data users to potential shifts in measured concentrations because of the correction of a deviation in the standard operating procedure used in the determination of trace elements, including dissolved selenium (Stetson and others, 2019). The deviation occurred from an unknown start date of no earlier than October 2005 (possibly as late as 2008) and ended August 8, 2015 (Stetson and others, 2019). The National Water Quality Laboratory performed experiments to examine the scope of the bias and found that dissolved selenium concentrations could be biased high by a median of 8.0 percent, compared to data determined from adherence to the standard operating procedure, but that variability was not appreciably affected (Stetson and others, 2019). The degree of bias was the same during the observed concentration ranges.

Samples for dissolved selenium were collected and analyzed by the USGS in the study area during this period. From October 2005 through August 8, 2015, a total of 211 dissolved selenium samples were collected at main-stem sites, 50 at Colorado River near Cameo (USGS 09095500), 64 at Gunnison River near Grand Junction (USGS 09152500), and 97 at Colorado River near Colorado-Utah State Line (USGS 09163500). Only two dissolved selenium samples were collected and analyzed at tributary sites, one at Adobe Creek at mouth (USGS 390741108424301) and one at Lewis Wash near Grand Junction (USGS 09106200) (table 1). These two dissolved selenium samples were not used in the analysis presented in this report. For the period of analysis used in this report, 58.8 percent of dissolved selenium samples at Colorado River near Cameo, 22.5 percent of dissolved selenium samples at Gunnison River near Grand Junction, and 26.6 percent of dissolved selenium samples at Colorado River near ColoradoUtah State Line were potentially affected by the bias.

The presence of bias in the dissolved selenium concentration data used in this report was examined. The approach selected to identify a dissolved selenium concentration laboratory bias relies on an unaffected relation between dissolved selenium concentrations and other major ion concentrations 
that were unaffected by changes in laboratory procedures. To test for laboratory bias, dissolved selenium data were split into two categories, termed "affected data" (collected between October 1, 2005 and August 8, 2015) and "unaffected data" (collected before October 1, 2005 or after August 8, 2015). Data collected prior to WY 2005 (October 1, 2004) were excluded from the analysis to limit complications arising from changes in method detection limits, extreme drought years, and trends in selenium concentrations. Identified major ions (including calcium, magnesium, sodium, chloride, and sulfate) were related to dissolved selenium molecular weight; and selection of linear models that explained the highest proportion of variance of dissolved selenium concentrations (during the unaffected period) were determined at each main-stem site. Residuals of affected and unaffected data from these regressions were used to assess the extent of laboratory bias present at each site. A Wilcoxon rank sum test was used to compare the difference in residuals between affected and unaffected data to quantify the significance.

At each site, the typical dissolved selenium concentration bias (in micrograms per liter $[\mu \mathrm{g} / \mathrm{L}]$ ) was calculated based on each selected major ion regression. The mean difference of the median residual values (between affected and unaffected periods) was determined as a concentration and percentage bias for each site using the corresponding median dissolved selenium concentration during the affected period.

The typical bias varied by site: positive 22.0 percent at Colorado River near Cameo, Colo., positive 4.5 percent at Gunnison River near Grand Junction, Colo., and positive 3.9 percent at Colorado River near Colorado-Utah State Line. This laboratory bias inflates reported selenium concentrations and loads during the affected period, with true loads potentially being less than those reported. The overall effect of this inflation is difficult to determine but was most pronounced at Colorado River near Cameo, Colo. Given the degree of variability associated with laboratory analysis for selenium in general, it is unlikely that the degree of laboratory bias associated with potential shifts in measured concentrations described by Stetson and others (2019) substantially changes the findings in this report other than increasing the regression analysis error that is reported. Robust analysis techniques (for example, weighted regressions on time, discharge, and season [WRTDS]) were used to address these issues within the waterquality data analysis.

\section{Statistical Summary of Available Data}

Statistical summaries were calculated for sites with E. coli and total recoverable iron data and sites with dissolved selenium data that did not have enough paired concentration and streamflow data to estimate an annual dissolved selenium load. For sites with $E$. coli data, statistical summaries included number of values, number of values with concentration greater than $126 \mathrm{CFU} / 100 \mathrm{~mL}$ (water-quality standard for $E$. coli in streams classified as primary contact recreational use [CDPHE, 2020]), range of sampling dates, range of concentrations, number of values with concentration greater than 2,420 CFU/100 mL (URL for undiluted samples), median concentration, geometric mean concentration, mean instantaneous load, median instantaneous load, and number of concentration and instantaneous streamflow pairs. For sites with total recoverable iron data, statistical summaries included number of values, range of sampling dates, range of concentrations, median concentration, mean instantaneous load, and number of concentration and instantaneous streamflow pairs. Statistical summaries for dissolved selenium data included number of values, range of sampling dates, range of concentrations, median concentration, 85th percentile concentration (for sites with five or more samples), mean instantaneous load, median instantaneous load, and number of concentration and instantaneous streamflow pairs.

For computation of median and geometric mean concentrations and mean and median instantaneous loads, E. coli values reported as greater than the URL were assigned a value of 2,420 CFU/100 mL. Consequently, the actual geometric mean concentration, mean instantaneous load, and median instantaneous load values for the sites are greater than the value computed. Fewer than 50 percent of samples from each site were reported as greater than the URL; as a result, computation of median concentrations was unaffected by sample concentrations greater than the URL.

\section{Estimating Selenium Loads, 85th Percentile Concentrations, and Load Reductions}

Historical water-quality and streamflow data for 29 tributary sites and 3 main-stem sites (table 1) were retrieved from the WQP. Samples from some sites included concurrent dissolved selenium concentration and streamflow data, whereas many others had only concentration data. A subset of these sites was not collocated at streamflow-gaging stations and had instantaneous streamflow measurements made at the time of sampling. The type and period of data collected at each site varied considerably, thus restricting the ability to properly characterize seasonal and temporal variability and calculate accurate loads at some sites. As no continuous and little instantaneous streamflow data were concurrent with $E$. coli and total recoverable iron concentrations, subsequent discussions on loads and load reductions pertain exclusively to dissolved selenium.

Three methods were used to address variable data density and to maximize the number of sites where loads could be calculated. For sites with low sample counts, typically less than 20, coincident samples (differing site identifiers but with similar location) were combined to provide a large sample population. For sites without continuous streamflow data where regular (seasonally defined) dissolved selenium and instantaneous streamflow data were collected for one or more WYs, a time-weighting technique was used for estimation of annual dissolved selenium loads (Crawford, 2004; Larson and others, 2004). For sites with continuous streamflow data, a regression analysis was used to estimate daily mean dissolved selenium concentrations from which estimated annual dissolved selenium loads and 85th percentile dissolved selenium 
concentrations were calculated. Dissolved selenium load reductions were determined for sites where the 85 th percentile dissolved selenium concentration exceeded the water-quality standard of $4.6 \mu \mathrm{g} / \mathrm{L}$, and an annual dissolved selenium load had been determined.

\section{Estimating Loads Using an Annual Time Weighted Mean}

For sites without continuous streamflow data and with seven or more samples that contained both selenium concentration and instantaneous streamflow data, an annual timeweighted mean (ATWM) was calculated that represents an annual selenium load in pounds per year. To evaluate a site with respect to ATWM, selenium concentrations and instantaneous streamflow data are needed to represent water-quality conditions for one or more WYs. Proportional representation of a WY implies that samples were collected during irrigation and nonirrigation seasons at relatively regular intervals. A dissolved selenium load was calculated for each matched pair of dissolved selenium concentration and instantaneous streamflow. Each calculated dissolved selenium load was assigned a weight based on the number of days between samples. Weights were computed as the amount of time extending from one-half the time interval between a sample and the preceding sample and one-half the time interval extending from the sample to the subsequent sample divided by the total time in a year. Weights were computed using the following general equation:

$$
W c=([1 / 2(D c-D p)-1 / 2(D c-D s)] / 36525) \times 100,(1)
$$

where

$W c$ is the weight for the sample, as a percentage;

$D c \quad$ is the date of the sample, in days;

$D p \quad$ is the date of the preceding sample, in days;

$D s \quad$ is the date of the subsequent sample, in days; and

365.25 is the number of days in a year to account for the extra day in leap years.

The weight was multiplied by the corresponding load, and the weighted loads were summed to represent the annual mean load for a given water year (Crawford, 2004; Larson and others, 2004). Similarly, time-weighted mean concentrations and daily loads were also computed for irrigation season (April 1 through October 31) and nonirrigation season (November 1 through March 31) for those years that had enough data to compute an annual mean load.

\section{Load Estimation Using Regression Analysis}

Regression techniques were used to estimate loads at main-stem and tributary sites in the study area when continuous streamflow data were available (Kircher and others, 1984; Butler, 1996; Mayo and Leib, 2012). On tributaries with enough and properly paired dissolved selenium and instantaneous streamflow data, the load estimating software R-LOADEST was used. R-LOADEST was derived from the FORTRAN program LOADEST (Runkel and others, 2004) and is used to estimate constituent loads in streams and rivers by using streamflow, time, seasonality, and other explanatory variables. R-LOADEST was used in the $\mathrm{R}$ statistical environment version 3.6.1 (R Core Team, 2019). Explanatory variables in the models include various functions of streamflow, time, and additional user-specified data variables. The formulated regression models are then used to estimate loads during a user-specified time interval. The calibration and estimation procedures within R-LOADEST are based on three statistical estimation methods. The first two methods, adjusted maximum likelihood estimation (AMLE) and maximum likelihood estimation (MLE), are appropriate when the calibration model errors (residuals) are normally distributed. Of the two, AMLE is the method of choice when the calibration dataset (streamflow, additional data variables, and constituent concentration) contains censored data. The third method, least absolute deviation, is an alternative to MLE methods when the residuals are not normally distributed. R-LOADEST output includes diagnostic tests and warnings to assist the user in determining the appropriate estimation method and in interpreting the estimated loads (Runkel and others, 2004; https://github.com/USGS-R/rloadest).

\section{Calculating the 85th Percentile of Selenium Concentrations}

Colorado's chronic aquatic-life water-quality standard for dissolved selenium is the 85th percentile concentration not to exceed $4.6 \mu \mathrm{g} / \mathrm{L}$ (CDPHE, 2020). Eighty-fifth percentile concentrations were computed for all sites with five or more dissolved selenium samples. The quantile function in $\mathrm{R}$ version 3.6.1 (R Core Team, 2019) was used to compute 85th percentile dissolved selenium concentrations for sites lacking sufficient data to calculate annual mean dissolved selenium loads. For sites where ATWM was used to estimate annual mean dissolved selenium loads, the 85 th percentile dissolved selenium concentration was computed from the proportionally weighted concentrations used to determine the ATWM load. For sites where R-LOADEST was used to estimate mean daily dissolved selenium concentrations, the 85 th percentile dissolved selenium concentration was computed from the estimated mean daily dissolved selenium concentrations.

\section{Load Reductions}

Load reductions were computed for dissolved selenium only. Samples for E. coli and total recoverable iron lacked adequate concurrent streamflow data to compute annual and seasonal loads. Load reductions represent the dissolved selenium load (pounds annually) reduction required to meet the chronic aquatic-life water-quality standard for dissolved selenium, 85th percentile concentration not to exceed $4.6 \mu \mathrm{g} / \mathrm{L}$ 
(CDPHE, 2020). Load-reduction calculations use the ratio of the aquatic-life water-quality standard to the 85 th percentile of a constituent's concentration (Thomas and others, 2008). Load reductions were determined for sites with annual mean dissolved selenium loads (ATWM or R-LOADEST methods). To determine if a load reduction would be needed at a site, the site was evaluated with respect to its 85 th percentile dissolved selenium concentration. If the 85 th percentile concentration exceeded the water-quality standard, the load reduction was calculated using a simple mass-balance approach. With this approach, Thomas and others (2008) assumed that the dissolved selenium load reduction would take place with no change in streamflow, selenium is primarily conservative in well aerated surface waters, and that only selenium would be removed from the system. Based on these assumptions, a new annual dissolved selenium load was determined that equaled the load that would result if the 85th percentile dissolved selenium concentration were to equal the water-quality standard of $4.6 \mu \mathrm{g} / \mathrm{L}$. This method of calculating load reductions uses the ratio of the water-quality standard to the 85 th percentile dissolved selenium concentration, which inherently preserves the distribution of the concentrations through the year. The hypothetical load at compliance with the water-quality standard was subtracted from the annual mean load, and the resulting value represents the amount of dissolved selenium load reduction required to bring the site into compliance with the water-quality standard. Load reduction was calculated for the following equation:

$$
L_{R}=L_{A}-\left(\frac{S T D[S e]}{85 t h[S e]}\right) L_{A},
$$

where
$L_{R} \quad$ is annual load reduction in pounds;
$L_{A} \quad$ is annual load at a site in pounds;
$\mathrm{STD}$ [Se] is $4.6 \mu \mathrm{g} / \mathrm{L}$ the State chronic aquatic-life standard for dissolved selenium; and
85th [Se] is the 85 th percentile selenium concentration at a site in micrograms per liter.

\section{Selenium Concentration and Load Analysis at Main-Stem Sites}

The WRTDS method (Hirsch and others, 2010) was used to estimate daily dissolved selenium concentrations during the period of record at each main-stem site. Concentration is modeled in WRTDS as

$$
\ln (c)=\beta_{0}+\beta_{1} t+\beta_{2} \ln (Q)+\beta_{3} \sin (2 \pi t)+\beta_{4} \cos (2 \pi t)+\varepsilon,
$$

where

$$
\begin{aligned}
\ln & \text { is natural } \log ; \\
c & \text { is concentration; }
\end{aligned}
$$

$\beta_{\mathrm{i}} \quad$ are fitted coefficients;

$Q \quad$ is daily mean streamflow;

$t \quad$ is decimal time; and

$\varepsilon \quad$ is unexplained variation.

Loads were calculated by multiplying sample concentrations or regression estimates by daily mean streamflow and a unit conversion constant. The fitted coefficients in most modeling approaches used in previous studies are constants, estimated to produce the best fit to the entire sample of measured concentrations (Hirsch and others, 2010). In contrast, the WRTDS model estimates a unique set of coefficients for every combination of $Q$ and $t$ in the period of record. The coefficients are fit by weighted regression, wherein the coefficients are given more value for observations collected under conditions that are similar to those on the day for which an estimate is required. The degree of similarity and weight on each observation are based on the distance in time, streamflow, and season. Concentration values observed within a year or two before or after the date for which an estimate is required affects the regression for that day more than concentration values observed 10 years before or after the date. Likewise, concentrations observed on days with streamflow within a couple of log cycles to the streamflow on the date of interest will be more heavily weighted than values collected under different streamflow conditions, and values collected during the same time of year affect the regression for a given date more than observations collected in a different season (Hirsch and others, 2010).

The variable-parameter weighted-regression approach allows WRTDS to represent complex relations between concentration and streamflow, as well as complex trends through time. Major features of the WRTDS method for concentration and load estimation include the ability to (1) accurately represent concentration-streamflow relations that change shape, seasonally, or through time; (2) detect and describe temporal trends that may not conform to linear or quadratic functional forms, in particular trends with more than one inflection point; and (3) characterize seasonal patterns that may change shape through time (Hirsch and others, 2010).

\section{Flow Adjusted Trend Analysis}

The WRTDS characterizes temporal changes in water quality using flow-normalized (FN) estimates of daily concentration and load (Hirsch and others, 2010). The FN estimates remove the variation in concentration or load because of random streamflow variations but not the variation because of nonrandom seasonal streamflow variation. The FN concentration for a day of interest (for example, June 5) is the mean of the set of concentration values determined by applying equation 3 with time and season fixed on June 5 repeated for all the daily mean streamflow values observed on that calendar day during the entire period of record (all values observed on June 5). Similarly, the FN load for a day of interest is the mean of the estimated load values from each of those weighted 
regressions. Daily values of FN concentration and load were aggregated to annual values by computing a mean of the daily FN values for each year. See Hirsch and De Cicco (2015) for more details and assumptions. Trends in FN values are the difference in $\mathrm{FN}$ values between 2 years expressed in either concentration or load units or as a percentage change relative to the starting value.

A substantial benefit of the trend computation used in WRTDS is the ability to estimate independent FN trends from concentration and load. Although concentration and load are tightly related, the changes that take place in one variable may be quite different from changes in the other (Hirsch and others, 2010). Annual mean concentration is a time mean of daily concentrations where the concentrations on the days of extremely high streamflow have the same effect on the mean as do the concentrations on days of moderate or low streamflow. In contrast, annual mean load is dominated by conditions on the days of the highest streamflow; and concentrations on days of extremely low streamflow are relatively inconsequential to the annual mean load. For example, mean concentrations could decrease throughout a period of years because of reductions in point-source contributions of a constituent, but mean loads could increase because of increase in a nonpoint source input that happens primarily on high-flow days. Given the potential for different trend results in concentration and load, the WRTDS model simulates load separately but in a consistent manner as concentration. This approach can provide greater insight into the trends occurring within a basin.

\section{Trend Uncertainty Analysis}

Descriptions of trends to be accompanied by statements of statistical significance, including confidence intervals on the amount of change observed, is desirable. The WRTDS Bootstrap Test is a block bootstrap approach evaluated using a set of Monte Carlo simulations to estimate Type I error probability, which is the probability of detecting a trend when one is not present, as compared to the null hypothesis that waterquality conditions have not changed throughout the period of analysis. The WRTDS Bootstrap Test output includes (1) hypothesis tests for trend flow-normalized concentration and flow-normalized load (reject or do not reject the null hypothesis at alpha $=0.1$ ), (2) p-values for those tests, (3) 90-percent confidence intervals for the magnitude of the trend in flownormalized concentration and flow-normalized load, and (4) likelihood statements (in numerical form and as descriptive statements) about trends in flow-normalized concentration and flow-normalized load. Likelihood designations are computed from the two-sided attained p-value and follow the pattern described in Hirsch and others (2015) where a range of likelihood values from 0.95 to 1.0 is considered "highly likely," 0.90 to $<0.95$ is "very likely," 0.67 to $<0.90$ is "likely," and 0.50 to $<0.67$ is "uncertain."

\section{Regression Analysis Software}

The WRTDS is implemented in the Exploration and Graphic for RivEr Trends (EGRET) R package (Hirsch and others, 2010; Hirsch and others, 2015) available from the Comprehensive R Archive Network at http://cran.r-project.org/ web/packages/. The WRTDS bootstrap test is also an R package, called EGRETci (Hirsch and others, 2015), and is also available from the Comprehensive R Archive Network.

\section{Analysis of $E$. coli, Total Recoverable Iron, and Dissolved Selenium Concentrations and Loading and Data Gaps}

This section of the report provides a summary of streamflow, E. coli, total recoverable iron, and dissolved selenium data collected from 1980 through 2018 at sites in the study area (fig. 1). Because limited streamflow data were concurrent with $E$. coli and total recoverable iron concentrations, only instantaneous loads were computed for these constituents.

One to five WYs of adequate data were available to estimate mean daily, annual, irrigation season, and nonirrigation season dissolved selenium loads and annual load reductions at eight tributary sites. Mean daily dissolved selenium concentrations and loads were estimated at three main-stem sites from WY 1980 to WY 2018 (Gunnison River near Grand Junction and Colorado River near Colorado-Utah State Line) and from WY 2002 to WY 2018 (Colorado River near Cameo). A trend analysis of annual dissolved selenium concentrations and loads was conducted across the entire year as well as during the irrigation season (April-October) and nonirrigation season (November-March). Seasonal trends could not be calculated across the entire period of analysis due to issues with overlapping water years, therefore, all trend analyses ended in WY 2017. Differences between upstream and downstream dissolved selenium contributions at the main-stem sites were used to estimate annual contributions of dissolved selenium from the Grand Valley.

\section{Streamflow}

Continuous streamflow data were available (U.S. Geological Survey, 2019) during the study period at mainstem sites on the Colorado River and Gunnison River that bracketed the study area. Streamflow and selenium data from these sites were used to calculate 85 th percentile concentrations for the main stem as well as estimate selenium loading from the Grand Valley. The lack of continuous streamflow data at some tributary sites limited the ability to estimate constituent loading. Continuous streamflow-gaging stations were historically operated at seven tributary sites. Five of these continuous streamflow-gaging stations were operated starting 
in the mid-1970s with most stations being discontinued by the mid-1980s, prior to the collection of water-quality data: Leach Creek at Durham (USGS 09152650), Adobe Creek near Fruita (USGS 09152900), Big Salt Wash at Fruita (USGS 09153270), Reed Wash near Loma (USGS 09153300), and Salt Creek near Mack (USGS 09163490). Only the Reed Wash near Mack (USGS 09153290) and Lewis Wash near Grand Junction (USGS 09106200) streamflow-gaging stations had limited concurrent water-quality and daily streamflow data. Loads at these sites were calculated where streamflow and concentration data were available.

Seasonal differences in streamflow values occur at the main-stem and tributary sites. In 2018, the highest streamflows at main-stem sites were measured during the early summer months of May and June as a result of snowmelt runoff, and the lowest streamflows were measured during the cool winter months, typically January and February (fig. 2A). At tributary sites, the highest streamflows were measured during the irrigation season from April to October when tributary reaches convey irrigation water (Leib, 2008). Figure $2 B$ shows the difference between monthly mean streamflows at Colorado River near Colorado-Utah State Line and combined streamflows at Colorado River near Cameo and Gunnison River near Grand Junction during 2018 to illustrate downstream changes in streamflow that result from irrigation diversions between main-stem sites.

\section{E. coli}

Samples were collected at five sites along Adobe Creek and at six sites along Leach Creek (fig. 3 and table 2), the two tributaries in the study area that are impaired for E. coli (CDPHE, 2016). Colorado's primary contact recreational use standard for $E$. coli is expressed as a two-month geometric mean not to exceed $126 \mathrm{CFU} / 100 \mathrm{~mL}$ (CDPHE, 2020). For the purposes of this report, a geometric mean was computed for each site using all concentration data. All geometric mean E. coli concentrations at sites along Adobe Creek and Leach Creek exceeded the $126 \mathrm{CFU} / 100 \mathrm{~mL}$ standard. The E. coli concentrations were generally higher in Adobe Creek than in Leach Creek (table 2). Continuous streamflow data were not available at any of these sites; however, four sites (Adobe Creek at K Road, Adobe Creek near mouth at 19 Road, Leach Creek at Summer Hill Drive, and Leach Creek at G Road and 25 Road upstream side of turnabout) had instantaneous streamflow measurements that were concurrent with samples collected in 2016 and 2017. Mean and median instantaneous E. coli loads were computed for these sites, but annual loads were not calculated, because the streamflow data were not adequate to represent seasonal variability within a WY. Thus, load reductions were not evaluated. Annual E. coli loads and load reductions can be evaluated for Adobe Creek and Leach Creek if future monitoring involves the collection of paired waterquality and streamflow samples that adequately represent seasonal variability within one or more WYs. Table 2 shows statistical summaries including number of values, number of values greater than $126 \mathrm{CFU} / 100 \mathrm{~mL}$ (water-quality standard for $E$. coli in streams classified as primary contact recreational use), range of sampling dates, range of concentrations, number of values greater than $2,420 \mathrm{CFU} / 100 \mathrm{~mL}$ (URL for undiluted samples), median concentration, geometric mean concentration, mean instantaneous load, median instantaneous load, and number of concentration and instantaneous streamflow pairs for sites with $E$. coli data.

\section{Adobe Creek E. coli Concentrations and Loads}

Adobe Creek near mouth at 19 Road (AC1) was sampled periodically from July 26, 2005, through June 8, 2010, during irrigation and nonirrigation seasons, and from June 7, 2016, through October 17, 2017, only during irrigation season. The median E. coli concentration for the period of record (2005 through 2017) was $749 \mathrm{CFU} / 100 \mathrm{~mL}$ (table 2), whereas the median concentration for samples collected during 2016 and 2017 was 921 CFU/100 mL (fig. 4). The E. coli concentrations may be higher in samples collected during 2016 and 2017, because samples were only collected during irrigation season (April through October) when temperatures were warmer and more conducive to bacteria growth.

Nineteen samples were collected at four additional sites along Adobe Creek from June 7, 2016, through October 17, 2017, to further characterize $E$. coli concentrations during irrigation season (April through October) and evaluate spatial variation in concentrations. Concentrations of $E$. coli ranged from 45.7 to more than 2,420 CFU/100 mL. Geometric mean concentrations ranged from $301 \mathrm{CFU} / 100 \mathrm{~mL}$ at Adobe Creek at $22 \mathrm{Road}(\mathrm{AC} 5)$ to $1,180 \mathrm{CFU} / 100 \mathrm{~mL}$ at Adobe Creek at J and 19.5 Road (AC2) (table 2).

Data collected during 2016 and 2017 were summarized to characterize the concentration and load profiles along Adobe Creek. Samples were collected on the same day at all sites along the stream reach to approximate steady-state conditions. The $E$. coli concentrations generally increased in the downstream direction; however, increases were not seen between all sites (table 2 and fig. 4). The largest downstream increase in $E$. coli concentration was measured between the two most upstream sites, Adobe Creek at 22 Road (AC5) and Adobe Creek upstream from Highline Canal at 21 Road (AC4); the median and geometric mean E. coli concentrations more than doubled between these sites (fig. 4 and table 2). The median E. coli concentration in Adobe Creek was lowest at the most upstream site, Adobe Creek at 22 Road (AC5), and highest at Adobe Creek at J and 19.5 Road (AC2). Between Adobe Creek at J and 19.5 Road (AC2) and Adobe Creek near mouth at 19 Road (AC1), the median E. coli concentration decreased from 1,300 to $921 \mathrm{CFU} / 100 \mathrm{~mL}$ in the downstream direction for data collected from June 7, 2016, through October 17, 2017 (fig. 4).

Instantaneous streamflow was measured at the time of sample collection at two sites on Adobe Creek (Adobe Creek at K Rd [AC3] and Adobe Creek near mouth at 19 Road 


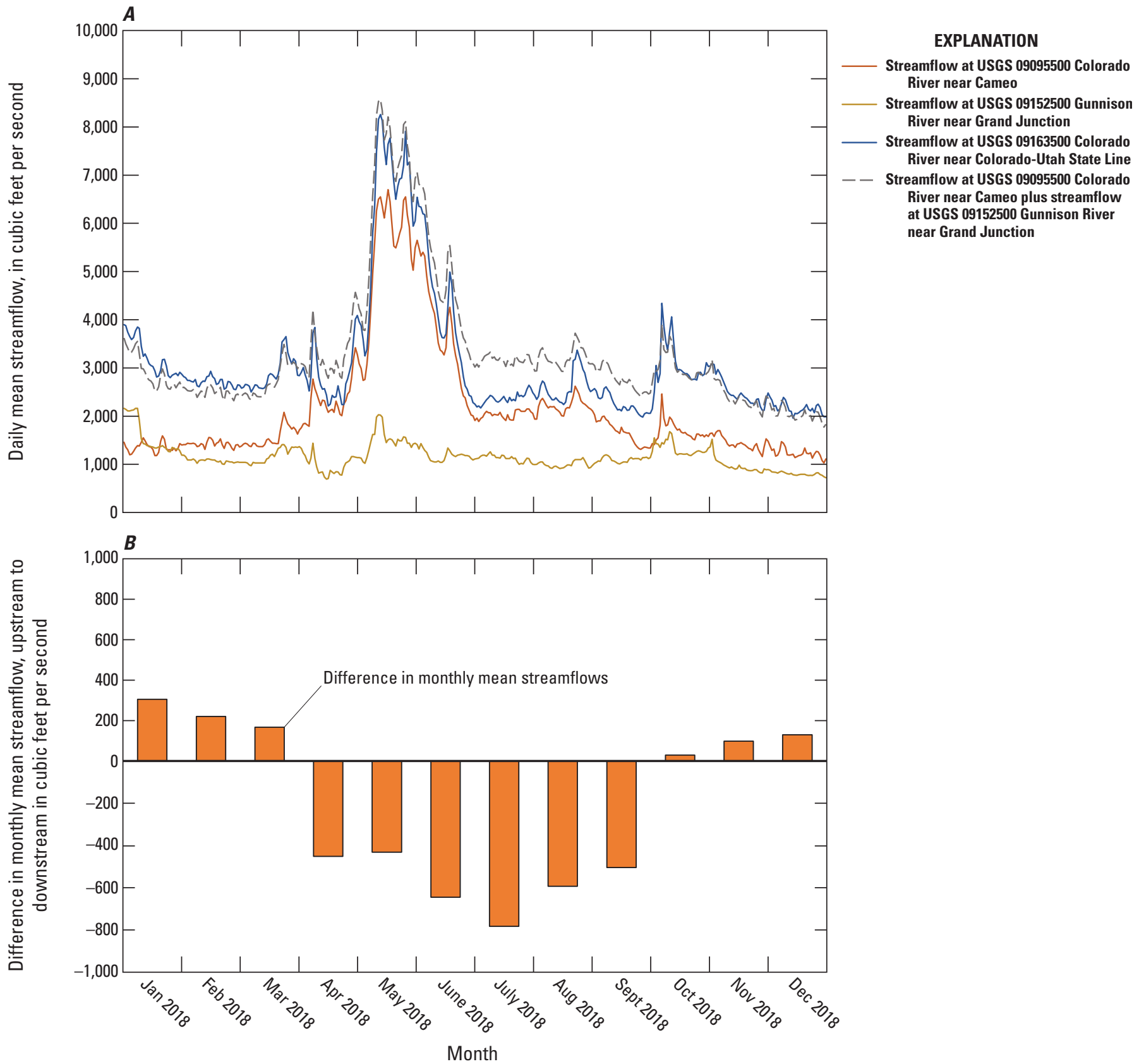

Figure 2. A, daily mean streamflow at select main-stem sites in the Grand Valley, Colorado; and $B$, difference in monthly mean streamflow between U.S. Geological (USGS) streamflow-gaging stations, Colorado River near Colorado-Utah State Line and Colorado River near Cameo plus Gunnison River near Grand Junction, 2018.

[AC1]) on some sample dates from June 7, 2016, through October 17, 2017. Diversions from Grand Valley Mainline Canal and Ranchmans Independent Ditch can enter Adobe Creek between the two sites (fig. 3). The median and geometric mean E. coli concentrations decreased between Adobe Creek at K Road (AC3) and Adobe Creek near mouth at 19 Road (AC1), and the instantaneous streamflow and median load more than doubled from 13.8 to 29.6 cubic feet per second $\left(\mathrm{ft}^{3} / \mathrm{s}\right)$ and 252 to 538 billion colony-forming units per day (giga-CFU/d), respectively (fig. 4 and table 2).

\section{Leach Creek Escherichia coliConcentrations and Loads}

Leach Creek at Durham (LC1) was sampled periodically from July 26, 2005, through June 7, 2010, during irrigation and nonirrigation seasons, and from June 7, 2016, through October 17, 2017, only during irrigation season. To further characterize E. coli concentrations along Leach Creek, 19 samples were collected at 5 additional sites from June 7, 2016, through October 17, 2017, during irrigation season (April 


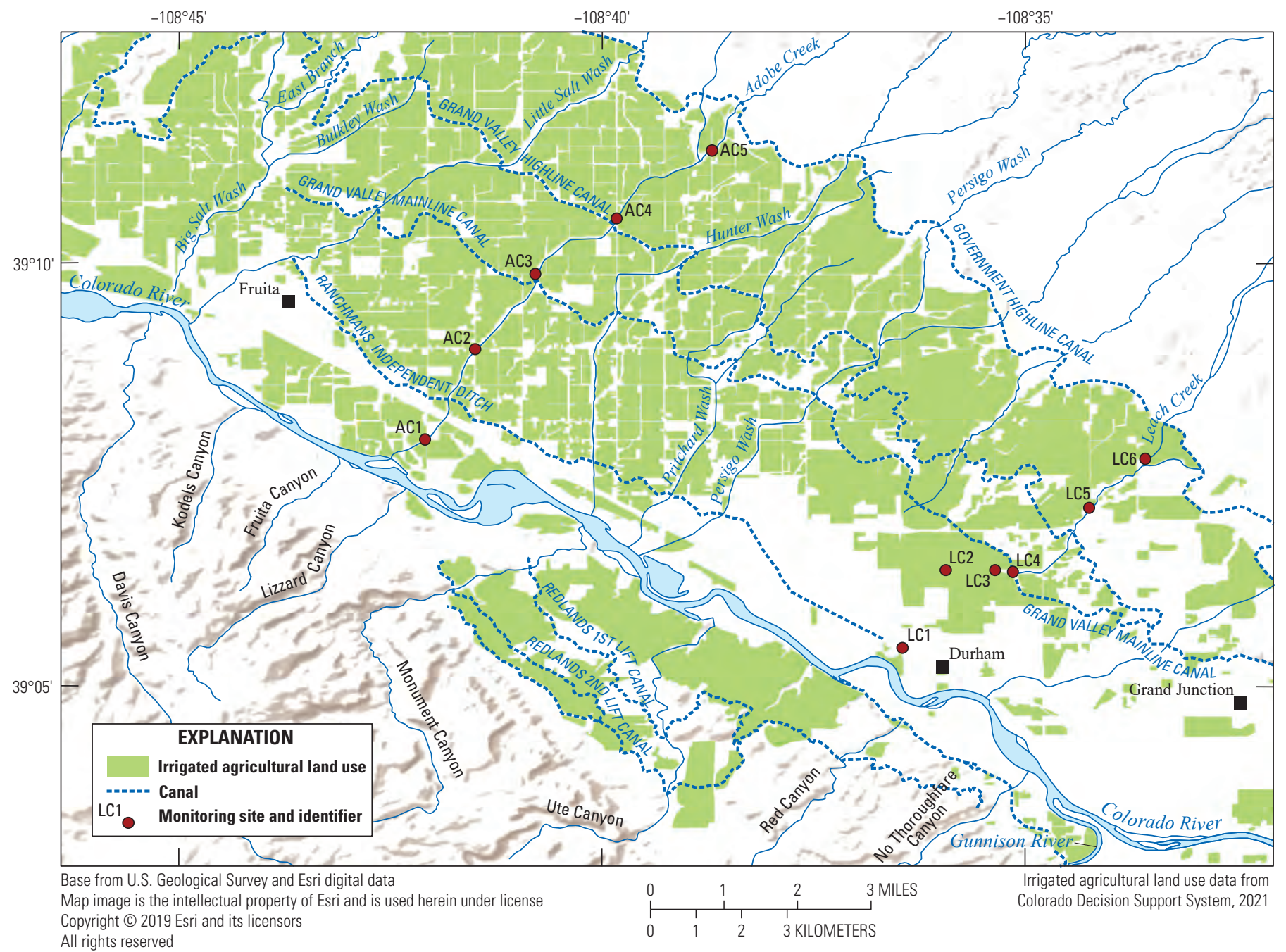

All rights reserved

Geographic projection, decimal degrees, meters

North American Datum 1983

Figure 3. Location of sample sites along Adobe Creek and Leach Creek.

through October). Samples were collected on the same day at all sites along the stream reach to approximate steady-state conditions. Concentrations of E. coli measured in samples ranged from 25.9 to more than $2,420 \mathrm{CFU} / 100 \mathrm{~mL}$. Geometric mean concentrations ranged from 160 at Leach Creek at $\mathrm{G}$ Road and 24.5 Road downstream side of turnabout (LC2) to 259 CFU/100 mL Leach Creek at Summer Hill Drive (LC6) (table 2).

Data collected along Leach Creek during 2016 and 2017 were summarized to characterize the concentration and load profiles. The E. coli concentrations showed no consistent downgradient increase (fig. $5 A$ ). In fact, some of the highest E. coli concentrations were measured at the most upstream site, Leach Creek at Summer Hill Drive (LC6). An increase in the median E. coli concentration was measured between Leach Creek at Summer Hill Road (LC6) and Leach Creek at 26 Road (LC5), followed by downgradient decreases between the next three sites (table 2 and fig. 5), with the lowest median concentration at Leach Creek at G Road and 24.5 Road downstream side of turnabout (LC2). The largest increase in median E. coli concentration was measured between the two most downstream sites, Leach Creek at G Road and 24.5 Road downstream side of turnabout (LC2) and Leach Creek at Durham (LC1). The median E. coli concentration increased from 162 to $272 \mathrm{CFU} / 100 \mathrm{~mL}$ (table 2).

Instantaneous streamflow was measured at the time of sample collection at Leach Creek at Summer Hill Drive (LC6) and Leach Creek at G Road and 25 Road upstream side of turnabout (LC3) on some sample dates from June 7, 2016, through October 17, 2017. Between these two sites, diversions from Government Highline Canal and Grand Valley Mainline Canal can enter Leach Creek (fig. 3). The median instantaneous streamflow and median E. coli instantaneous load increased from 0.21 to $12.4 \mathrm{ft}^{3} / \mathrm{s}$ and 0.64 to 96 giga-CFU/d, respectively (table 2 and fig. 5). 
Table 2. Statistical summary of Escherichia coli concentration data for 303(d) listed segments (Colorado Department of Public Health and Environment, 2016) with limited datasets in the Grand Valley, western Colorado, 2005-17.

[For computation of median and geometric mean concentrations and median instantaneous loads, values reported as above the upper reporting limit were assigned a value of 2,420 colony-forming units per 100 milliliters (CFU/100 mL). giga-CFU, 1 billion colony forming units; >, greater than; NA, no data available]

\begin{tabular}{|c|c|c|c|c|c|c|c|c|c|c|c|c|}
\hline $\begin{array}{c}\text { Site } \\
\text { name }\end{array}$ & $\begin{array}{c}\text { Site } \\
\text { identifier }\end{array}$ & $\begin{array}{l}\text { Monitoring } \\
\text { site } \\
\text { identifier } \\
\text { (fig. 3) }\end{array}$ & $\begin{array}{l}\text { Number } \\
\text { of } \\
\text { values }\end{array}$ & $\begin{array}{c}\begin{array}{c}\text { Number } \\
\text { of values } \\
>126\end{array} \\
\text { CFU/100 mL }\end{array}$ & $\begin{array}{l}\text { Range } \\
\text { of } \\
\text { sampling } \\
\text { dates }\end{array}$ & $\begin{array}{l}\text { Range of } \\
\text { concentrations } \\
\text { (CFU/100 mL) }\end{array}$ & $\begin{array}{c}\text { Number of } \\
\text { values }>2,420 \\
\text { CFU/100 mL }\end{array}$ & $\begin{array}{c}\text { Median } \\
\text { concentration } \\
\text { (CFU/100 mL) }\end{array}$ & $\begin{array}{c}\begin{array}{c}\text { Geometric } \\
\text { mean } \\
\text { concentration } \\
\text { (CFU/100 mL) }\end{array}\end{array}$ & $\begin{array}{c}\text { Mean } \\
\text { instant- } \\
\text { aneous load } \\
\text { (giga-CFU/ } \\
\text { day) }\end{array}$ & $\begin{array}{c}\text { Median } \\
\text { instantaneous } \\
\quad \text { load } \\
\text { (giga-CFU/day) }\end{array}$ & $\begin{array}{l}\text { Number of } \\
\text { concentration } \\
\text { and stream- } \\
\text { flow pairs } \\
\text { used to } \\
\text { calculate loads }\end{array}$ \\
\hline Adobe Creek at 22 Road & 21COL001_WQX-TMDL-AC5 & AC5 & 19 & 14 & $\begin{array}{c}06 / 07 / 2016 \text { to } \\
10 / 17 / 2017\end{array}$ & $45.7-1,410$ & 0 & 416 & 301 & NA & NA & NA \\
\hline $\begin{array}{l}\text { Adobe Creek upstream } \\
\text { from Highline Canal } \\
\text { at } 21 \text { Road }\end{array}$ & 21COL001_WQX-TMDL-AC4 & $\mathrm{AC} 4$ & 19 & 19 & $\begin{array}{l}06 / 07 / 2016 \text { to } \\
10 / 17 / 2017\end{array}$ & $194->2,420$ & 3 & 1,050 & 762 & NA & NA & NA \\
\hline Adobe Creek at K Road & 21COL001_WQX-TMDL-AC3 & $\mathrm{AC} 3$ & 19 & 18 & $\begin{array}{l}06 / 07 / 2016 \text { to } \\
10 / 17 / 2017\end{array}$ & $117->2,420$ & 3 & 816 & 821 & 329 & 252 & 14 \\
\hline $\begin{array}{l}\text { Adobe Creek at } J \text { and } \\
\quad 19.5 \text { Road }\end{array}$ & 21COL001_WQX-TMDL-AC2 & $\mathrm{AC} 2$ & 19 & 19 & $\begin{array}{c}06 / 07 / 2016 \text { to } \\
10 / 17 / 2017\end{array}$ & $228->2,420$ & 6 & 1,300 & 1,180 & NA & NA & NA \\
\hline $\begin{array}{l}\text { Adobe Creek near } \\
\text { mouth at } 19 \text { Road }\end{array}$ & $\begin{array}{l}\text { 21COL001_WQX-11133, } \\
\text { 21COL001-11133, and } \\
\text { 21COL001_WQX-TMDL- } \\
\text { AC1 }\end{array}$ & $\mathrm{AC} 1$ & 36 & 36 & $\begin{array}{c}07 / 26 / 2005 \text { to } \\
10 / 17 / 2017\end{array}$ & $147->2,420$ & 6 & 749 & 738 & 693 & 538 & 14 \\
\hline $\begin{array}{l}\text { Leach Creek at Summer } \\
\text { Hill Drive }\end{array}$ & 21COL001_WQX-TMDL-LC6 & LC6 & 19 & 13 & $\begin{array}{l}06 / 07 / 2016 \text { to } \\
10 / 17 / 2017\end{array}$ & $25.9->2,420$ & 2 & 185 & 259 & 1.7 & 0.64 & 12 \\
\hline Leach Creek at 26 Road & 21COL001_WQX-TMDL-LC5 & LC5 & 19 & 14 & $\begin{array}{c}06 / 07 / 2016 \text { to } \\
10 / 17 / 2017\end{array}$ & $54.6-1,200$ & 0 & 214 & 216 & NA & NA & NA \\
\hline $\begin{array}{l}\text { Leach Creek upstream } \\
\text { from Grand Valley } \\
\text { Canal }\end{array}$ & 21COL001_WQX-TMDL-LC4 & LC4 & 19 & 13 & $\begin{array}{l}06 / 07 / 2016 \text { to } \\
10 / 17 / 2017\end{array}$ & $56.3-921$ & 0 & 210 & 178 & NA & NA & NA \\
\hline $\begin{array}{l}\text { Leach Creek at G } \\
\text { Road and } 25 \text { Road } \\
\text { upstream side of } \\
\text { turnabout }\end{array}$ & 21COL001_WQX-TMDL-LC3 & LC3 & 19 & 13 & $\begin{array}{c}06 / 07 / 2016 \text { to } \\
10 / 17 / 2017\end{array}$ & $48.7-727$ & 0 & 186 & 197 & 106 & 96 & 14 \\
\hline $\begin{array}{l}\text { Leach Creek at G Road } \\
\text { and } 24.5 \text { Road } \\
\text { downstream side of } \\
\text { turnabout }\end{array}$ & 21COL001_WQX-TMDL-LC2 & LC2 & 19 & 12 & $\begin{array}{c}06 / 07 / 2016 \text { to } \\
10 / 17 / 2017\end{array}$ & $34.5-921$ & 0 & 162 & 160 & NA & NA & NA \\
\hline Leach Creek at Durham & $\begin{array}{l}\text { 21COL001_WQX-11135, } \\
\text { 21COL001-11135, and } \\
\text { 21COL001_WQX-TMDL- } \\
\text { LC1 }\end{array}$ & LC1 & 33 & 27 & $\begin{array}{l}07 / 26 / 2005 \text { to } \\
10 / 17 / 2017\end{array}$ & $44.1-548$ & 0 & 272 & 231 & NA & NA & NA \\
\hline
\end{tabular}




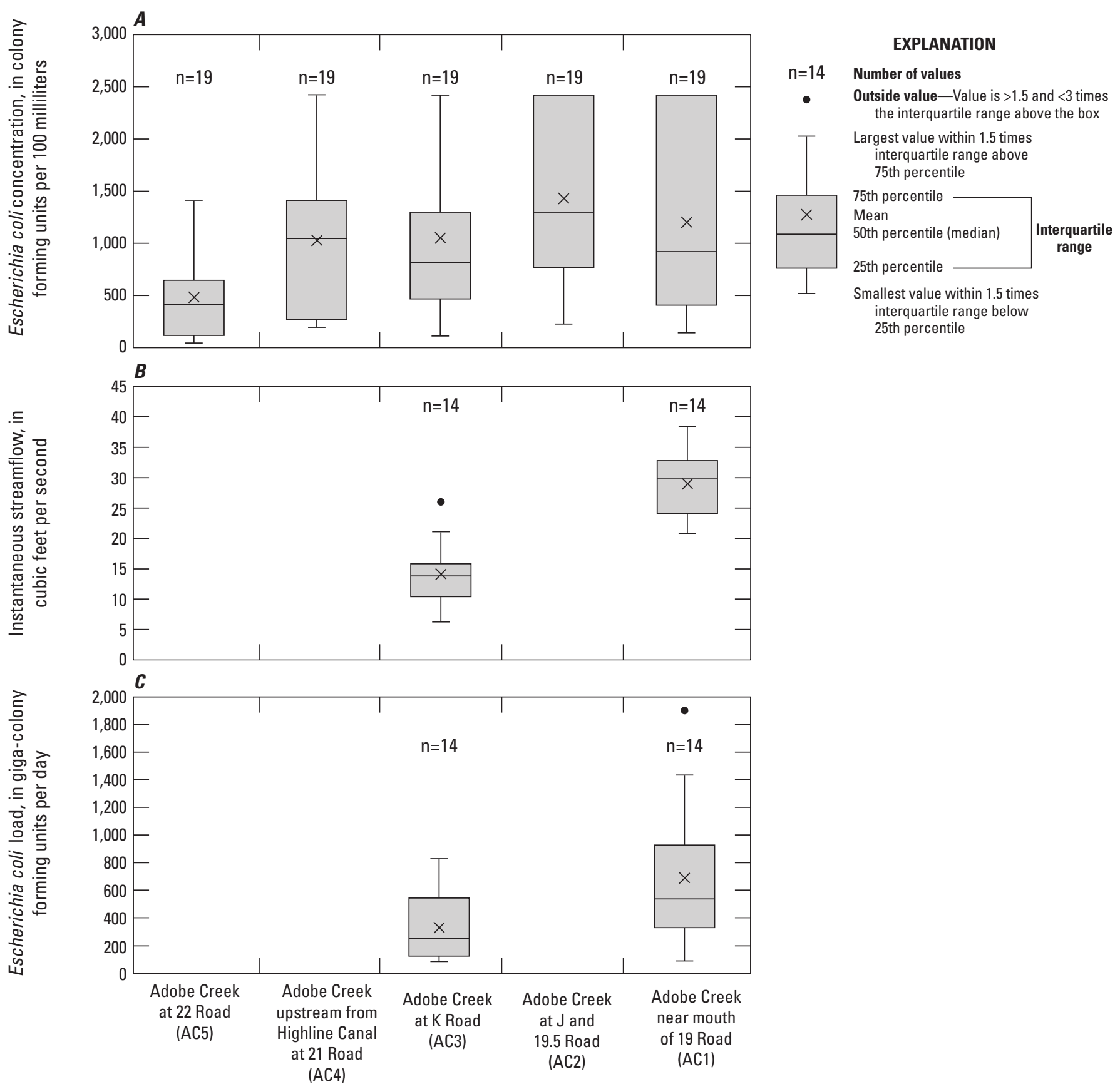

Figure 4. Downstream profile of $A$, Escherichia coli concentrations; $B$, instantaneous streamflow; and $C$, Escherichia coli loads along Adobe Creek, 2016-17.

\section{Sources of E. coli}

E. coli is associated with fecal matter, and common sources include animal waste, leaking sewer lines or septic systems, and wastewater treatment systems (Clary and others, 2014). In the study area, E. coli concentrations were higher during irrigation season when temperatures were warmer and more conducive to bacteria growth. Concentrations did not consistently increase in the downstream direction, and in Leach Creek some of the highest concentrations were at the most upstream site. Different types of land use may be responsible for the observed variations in E. coli concentration. There is more residential and urban development in the lower portions of the Adobe Creek and Leach Creek drainage areas and more agricultural land use in the upper portions; however, residential development in the Grand Valley is increasing (Leib, 2008). Sources of E. coli to Adobe and Leach Creeks could include livestock in agricultural areas and urban runoff and septic systems in residential areas. Differences in E. coli concentrations can 


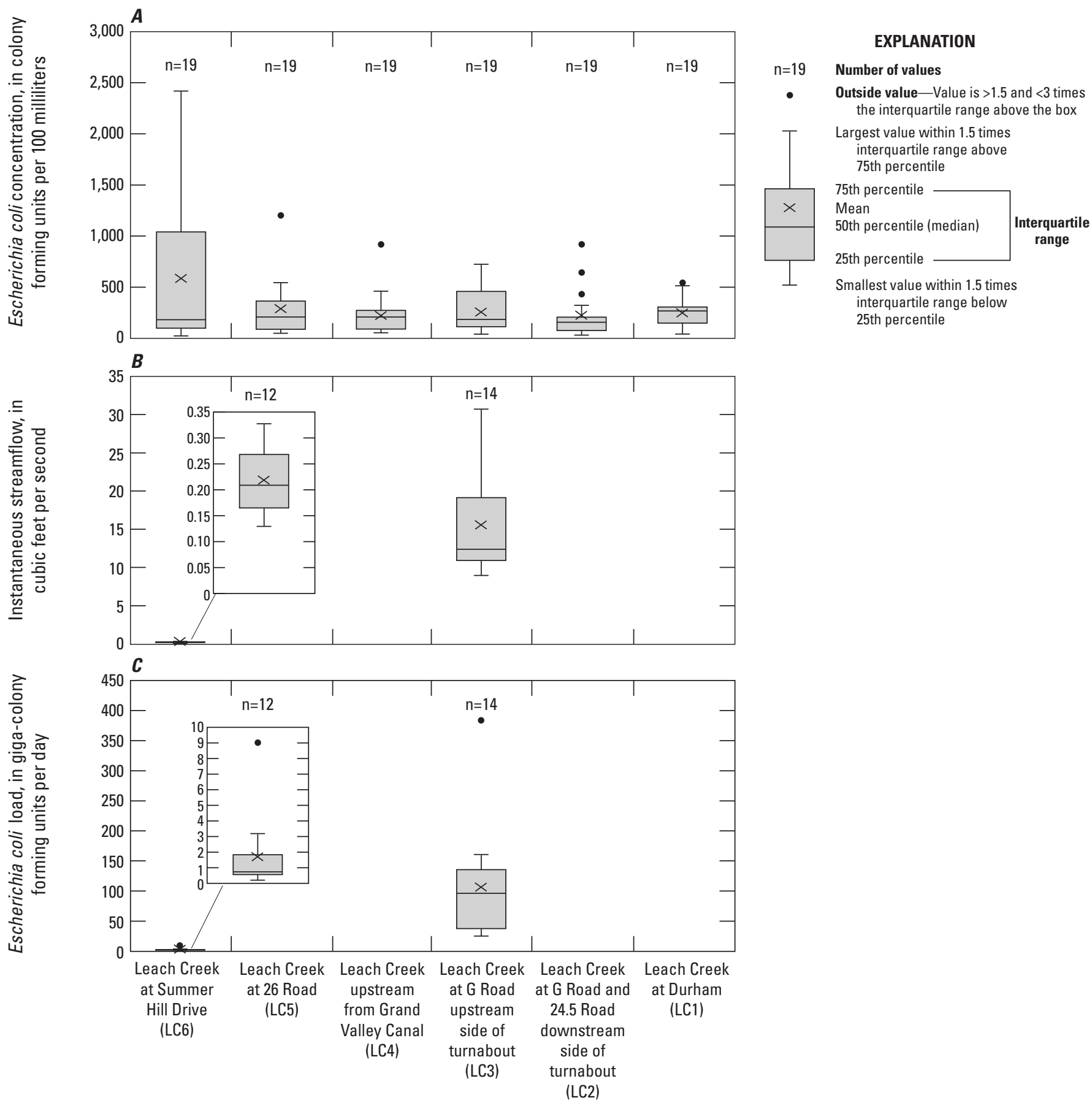

Figure 5. Downstream profile of $A$, Escherichia coli concentrations; $B$, instantaneous streamflow; and $C$, Escherichia coli loads along Leach Creek, 2016-17.

also be affected by storms. Streams can have high concentrations of $E$. coli after rainfall as runoff washes bacteria, sediment, and other contaminants off the land and into surface water (Clary and others, 2014; Miller and Stogner, 2017). High turbidity is often correlated with high $E$. coli concentrations because bacteria can be attached to particles, and the particles can protect the bacteria from ultraviolet radiation (Clary and others, 2014).

\section{Total Recoverable Iron}

Total recoverable iron concentrations and loads were evaluated at 15 tributary sites for samples collected from August 1993 to February 2018 (table 3). Few samples were collected before 2002, and most samples were collected during 2016 and 2017. Sites were located on Adobe Creek, Appleton Drain, Big Salt Wash, Hunter Wash, Indian Wash, Leach Creek, Lewis Wash, Little Salt Wash, Persigo Wash, Pritchard 
Table 3. Statistical summary of total recoverable iron concentration data for sites on 303(d) listed segments (Colorado Department of Public Health and Environment, 2016) with limited datasets in the Grand Valley, western Colorado, 1993-2018.

[Loads were not computed for sites with less than three concentration and streamflow pairs. $\mu \mathrm{g} / \mathrm{L}$, micrograms per liter; lb/d, pounds per day; NA, no value computed]

\begin{tabular}{|c|c|c|c|c|c|c|c|c|c|c|}
\hline $\begin{array}{c}\text { Site } \\
\text { name }\end{array}$ & $\begin{array}{c}\text { Site } \\
\text { identifier(s) }\end{array}$ & $\begin{array}{l}\text { Number } \\
\text { of } \\
\text { values }\end{array}$ & $\begin{array}{l}\text { Range } \\
\text { of } \\
\text { sampling } \\
\text { dates }\end{array}$ & $\begin{array}{c}\begin{array}{c}\text { Range } \\
\text { of } \\
\text { concentrations } \\
(\mu \mathrm{g} / \mathrm{L})\end{array}\end{array}$ & $\begin{array}{c}\text { Median } \\
\text { concentration } \\
(\mu \mathrm{g} / \mathrm{L})\end{array}$ & $\begin{array}{l}\text { Median } \\
\text { irrigation } \\
\text { season } \\
\text { concentration } \\
(\mu \mathrm{g} / \mathrm{L})\end{array}$ & $\begin{array}{c}\text { Median } \\
\text { nonirrigation } \\
\text { season } \\
\text { concentration } \\
(\mu \mathrm{g} / \mathrm{L})\end{array}$ & $\begin{array}{l}\text { Mean } \\
\text { instantaneous } \\
\text { load (lb/d) }\end{array}$ & $\begin{array}{l}\text { Median } \\
\text { instantaneous } \\
\text { load (lb/d) }\end{array}$ & $\begin{array}{l}\text { Number of } \\
\text { concentration and } \\
\text { instantaneous } \\
\text { streamflow pairs } \\
\text { used to calculate } \\
\text { loads }\end{array}$ \\
\hline $\begin{array}{l}\text { Adobe Creek near mouth at } \\
19 \text { Road }\end{array}$ & $\begin{array}{l}\text { 21COL001_WQX-TMDL-LC16, } \\
\text { 21COL001_WQX-11133, } \\
\text { 21COL001-11133, and } \\
\text { 21COL001_WQX-TMDL-AC1 }\end{array}$ & 37 & $\begin{array}{r}07 / 26 / 2005 \text { to } \\
02 / 07 / 2018\end{array}$ & $103-18,000$ & 2,700 & 3,200 & 250 & 331 & 347 & 10 \\
\hline $\begin{array}{l}\text { Appleton Drain upstream } \\
\text { from Colorado River }\end{array}$ & 21COL001_WQX-TMDL-ADT & 9 & $\begin{array}{r}10 / 14 / 2015 \text { to } \\
01 / 24 / 2018\end{array}$ & $100-6,580$ & 530 & 574 & 100 & 146 & 32 & 5 \\
\hline Big Salt Wash at Fruita & $\begin{array}{l}\text { CORIVWCH_WQX-4061, } \\
\text { 21COL001_WQX-TMDL- } \\
\text { BSWT2, USGS-09153270 }\end{array}$ & 18 & $\begin{array}{r}08 / 13 / 1997 \text { to } \\
02 / 07 / 2018\end{array}$ & $116-13,200$ & 818 & 3,100 & 369 & 1,460 & 142 & 15 \\
\hline $\begin{array}{l}\text { Big Salt Wash downstream } \\
\text { from I-70 }\end{array}$ & $\begin{array}{l}\text { CORIVWCH_WQX-3263, } \\
\text { 21COL001_WQX-TMDL-BSWT }\end{array}$ & 13 & $\begin{array}{r}08 / 09 / 1993 \text { to } \\
07 / 17 / 2017\end{array}$ & $175-9,590$ & 3,590 & 3,590 & NA & NA & NA & NA \\
\hline Hunter Wash at River Road & CORIVWCH_WQX-4063 & 12 & $\begin{array}{r}03 / 20 / 2002 \text { to } \\
12 / 06 / 2007\end{array}$ & $97-1,070$ & 211 & NA & 211 & 9.6 & 3 & 9 \\
\hline $\begin{array}{l}\text { Hunter Wash upstream } \\
\text { from Colorado River }\end{array}$ & 21COL001_WQX-TMDL-HWT & 18 & $\begin{array}{r}08 / 08 / 2012 \text { to } \\
02 / 07 / 2018\end{array}$ & $140-7,010$ & 2,550 & 2,810 & 159 & 546 & 461 & 6 \\
\hline Indian Wash at C $1 / 2$ Road & 21COL001_WQX-11135B & 10 & $\begin{array}{r}08 / 10 / 2009 \text { to } \\
06 / 18 / 2012\end{array}$ & $29-6,700$ & 935 & 2,200 & 245 & NA & NA & NA \\
\hline Leach Creek at Durham & $\begin{array}{l}\text { 21COL001-11135, } \\
\text { 21COL001_WQX-11135, } \\
\text { 21COL001_WQX-TMDL-LC1, } \\
\text { USGS-09152650 }\end{array}$ & 32 & $\begin{array}{r}08 / 13 / 1997 \text { to } \\
01 / 24 / 2018\end{array}$ & $120-30,000$ & 1,550 & 1,740 & 295 & NA & NA & NA \\
\hline $\begin{array}{l}\text { Lewis Wash near Grand } \\
\text { Junction }\end{array}$ & $\begin{array}{l}\text { 21COL001_WQX-TMDL-LC09, } \\
\text { CORIVWCH_WQX-4064 }\end{array}$ & 6 & $\begin{array}{r}12 / 18 / 2003 \text { to } \\
06 / 19 / 2012\end{array}$ & $98-1,120$ & 353 & 490 & 337 & 3.9 & 0.3 & 6 \\
\hline $\begin{array}{l}\text { Little Salt Wash at High- } \\
\text { way } 50 \text { at Fruita }\end{array}$ & $\begin{array}{l}\text { 21COL001_WQX-TMDL-LSWT, } \\
\text { 21COL001_WQX-TMDL-LSWT2 }\end{array}$ & 10 & $\begin{array}{r}07 / 11 / 2016 \text { to } \\
01 / 23 / 2018\end{array}$ & $720-10,500$ & 2,100 & 2,200 & 720 & 1,110 & 818 & 7 \\
\hline $\begin{array}{l}\text { Persigo Wash at mouth } \\
\text { near Fruita }\end{array}$ & $\begin{array}{l}\text { 21COL001_WQX-TMDL-LC15, } \\
\text { 21COL001_WQX-TMDL-PSWT }\end{array}$ & 16 & $\begin{array}{r}03 / 14 / 2012 \text { to } \\
02 / 07 / 2018\end{array}$ & $50-6,100$ & 1,220 & 1,500 & 200 & 528 & 329 & 8 \\
\hline $\begin{array}{l}\text { Pritchard Tributary } \\
\text { upstream from Colorado } \\
\text { River }\end{array}$ & 21COL001_WQX-TMDL-PRT & 12 & $\begin{array}{r}10 / 14 / 2015 \text { to } \\
02 / 07 / 2018\end{array}$ & $850-6,280$ & 2,250 & 2,700 & 1,190 & 276 & 288 & 7 \\
\hline Reed Wash near Fruita & $\begin{array}{l}\text { 21COL001_WQX-TMDL-RWT1, } \\
\text { CORIVWCH_WQX-4073 }\end{array}$ & 6 & $\begin{array}{r}10 / 29 / 2001 \text { to } \\
09 / 11 / 2012\end{array}$ & $191-2,430$ & 249 & 2,230 & 222 & 292 & 11 & 5 \\
\hline Reed Wash near Loma & $\begin{array}{l}\text { 21COL001_WQX-TMDL-RWT, } \\
\text { 21COL001_WQX-TMDL-LC22, } \\
\text { USGS-09153300 }\end{array}$ & 17 & $\begin{array}{r}08 / 13 / 1997 \text { to } \\
01 / 23 / 2018\end{array}$ & $29-11,000$ & 4,670 & 5,620 & 89.5 & 1,620 & 7.3 & 3 \\
\hline Salt Creek near Mack & $\begin{array}{l}\text { 21COL001-11130, 21COL001_WQX- } \\
\text { TMDL-SCT, USGS-09163490 }\end{array}$ & 7 & $\begin{array}{r}08 / 13 / 1997 \text { to } \\
10 / 13 / 2015\end{array}$ & $633-11,900$ & 2,110 & 2,110 & NA & NA & NA & NA \\
\hline
\end{tabular}


Wash, Reed Wash, and Salt Creek (table 3). Continuous streamflow data were not available, but 11 sites had concurrent concentration and instantaneous streamflow data that were used to compute a mean and median instantaneous load. For total recoverable iron, the chronic aquatic-life water-quality standard is the 50th percentile or median total recoverable iron concentration not to exceed 1,000 $\mu \mathrm{g} / \mathrm{L}$ (CDPHE, 2020). Table 3 includes number of values, range of sampling dates, range of concentrations, median concentration, median irrigation season concentration, median nonirrigation season concentration, mean instantaneous load, median instantaneous load, and number of concentration and instantaneous streamflow pairs for sites with total recoverable iron data.

Median total recoverable iron concentrations ranged from 211 to $4,670 \mu \mathrm{g} / \mathrm{L}$ (table 3). The chronic aquatic-life water-quality standard was exceeded in most irrigation season samples but was rarely exceeded in nonirrigation season samples. Concentrations were often an order of magnitude higher in samples collected during irrigation season than in samples collected during nonirrigation season. For example, at Adobe Creek near mouth at 19 Road, the median total recoverable iron concentration was $250 \mu \mathrm{g} / \mathrm{L}$ for nonirrgation season samples and 3,200 $\mu \mathrm{g} / \mathrm{L}$ for irrigation season samples. Not all sites had data for both irrigation and nonirrigation seasons (table 3). Samples were collected only during nonirrigation season at Hunter Wash at River Road. This site had the lowest median total recoverable iron concentration $(211 \mu \mathrm{g} / \mathrm{L})$ in table 3. Downstream, at Hunter Wash upstream from Colorado River, the median total recoverable iron concentration was $2,550 \mu \mathrm{g} / \mathrm{L}$ (table 3). Concentrations of total recoverable iron were similar at both Hunter Wash sites in nonirrigation season samples. The large difference in median concentration values is likely because 16 of the 18 samples at Hunter Wash upstream from Colorado River were collected during irrigation season when streamflow and total recoverable iron concentrations were higher than nonirrigation season values. Consequently, the increase in median total recoverable iron concentration between Hunter Wash at River Road and Hunter Wash upstream from Colorado River does not necessarily indicate an increase in total recoverable iron concentration but rather different sampling strategies.

Instantaneous streamflow values, measured at the time of sample collection, were available for some samples at 11 sites. Most of the paired concentration and streamflow samples for sites at the mouth of a tributary were collected during irrigation season in 2016 and 2017; however, there were some exceptions. The mean instantaneous load for Lewis Wash near Grand Junction is based on six paired samples that were collected between 2003 and 2012 (table 3), and five of those samples were collected during nonirrigation season. The mean instantaneous load for Reed Wash near Loma is based on three paired concentration and streamflow values that were collected during 1997, 2012, and 2018, with only the 1997 pair collected during irrigation season. The mean instantaneous load estimates for Lewis Wash near Grand Junction and Reed Wash near Loma could be improved by the addition of paired streamflow and total recoverable iron samples collected during irrigation season to account for seasonal variability in concentrations and loads.

Only 2 sites had 10 or more concentration and streamflow pairs, Adobe Creek near mouth at 19 Road and Big Salt Wash at Fruita (table 3). Instantaneous streamflow values ranged from 2.07 to $38.4 \mathrm{ft}^{3} / \mathrm{s}$ at Adobe Creek near mouth at $19 \mathrm{Road}$ and from 5.9 to $123 \mathrm{ft}^{3} / \mathrm{s}$ at Big Salt Wash at Fruita (National Water Quality Monitoring Council, 2019; https://www. waterqualitydata.us/). The mean instantaneous loads at Adobe Creek near mouth at 19 Road and Big Salt Wash at Fruita were 331 pounds per day $(\mathrm{lb} / \mathrm{d})$ and $1,460 \mathrm{lb} / \mathrm{d}$, respectively (table 3 ).

As with E. Coli, the lack of concurrent streamflow information is a data gap. None of the sites had enough streamflow data to compute annual loads. Collection of additional concentration and streamflow pairs could improve the estimates of instantaneous loads and enable calculation of annual loads and load reductions, if the data adequately represent streamflow variability within a water year. Streamflow increases substantially during irrigation season and decreases during nonirrigation season in the study area (fig. 2). Total recoverable iron concentrations were often an order of magnitude higher during irrigation season compared to nonirrigation season. Seasonal variations in total recoverable iron concentrations have been observed in other basins in Colorado. Total dissolved iron concentrations were higher from March through May at a site in the Colorado River Basin upstream of the study area, and the seasonal difference may have resulted from resuspension of sediments during high streamflow (Williams and others, 2011). Walker (2014) found that total recoverable iron concentrations were highest from March through June and attributed the seasonal pattern to spring runoff that led to erosion and increased suspended sediment entering some streams within a subbasin in the Colorado River Basin near Glenwood Springs.

Previous monitoring in the study area has involved collection of samples that were analyzed for dissolved-iron concentrations. If future samples are analyzed for both dissolved iron and total recoverable iron, it may be possible to determine a correlation between the two concentrations. If a correlation exists, it could potentially be used to expand the dataset by inferring total recoverable iron concentrations from the past dissolved iron data.

\section{Dissolved Selenium Concentrations and Loads}

Dissolved selenium concentrations and loads were evaluated at a total of 20 tributary sites and 3 main-stem sitesColorado River near Cameo (USGS 09095500), Gunnison River near Grand Junction (USGS 09152500), and Colorado River near Colorado-Utah State Line (USGS 09163500). Tributary sites were located on Adobe Creek, Appleton Drain, Big Salt Wash, Hunter Wash, Indian Wash, Leach Creek, Lewis Wash, Little Salt Wash, Persigo Wash, Pritchard Wash, Reed Wash, and Salt Creek. The number of samples, period of sample collection, and availability of concurrent streamflow data varied from site to site. 


\section{Tributary Dissolved Selenium Concentrations and Loads}

Three methods were used to address variable data density and to maximize the number of sites where loads could be calculated at tributary sites. Statistical summaries were computed using instantaneous dissolved selenium and streamflow data collected from 1991 through 2018 for 14 tributary sites with limited or inadequate data to compute an annual dissolved selenium load (table 4). For sites without continuous streamflow data, with seven or more samples that contained both dissolved selenium concentration and instantaneous streamflow data, an ATWM was determined that represents an annual selenium load in pounds per year. The ATWM method (described in the Methods section of this report) was used to estimate mean daily loads, annual loads, irrigation season and nonirrigation season mean loads, and annual load reductions for seven tributary sites. Each of these sites had adequate data to represent seasonal variability for at least one WY from 1992 to 2001 (table 5). Only one tributary site, Lewis Wash near Grand Junction, had adequate data to complete a selenium loading analysis using the regression analysis (R-LOADEST) method.

\section{Dissolved Selenium Concentrations and Instantaneous Loads at Tributary Sites}

Statistical summaries for dissolved selenium data including number of values, range of sampling dates, range of concentrations, median concentration, 85 th percentile concentration (for sites with 5 or more samples), mean instantaneous load, median instantaneous load, and number of concentration and instantaneous streamflow pairs for 14 tributary sites are shown in table 4. Dissolved selenium concentrations in samples ranged from 1.9 to $120 \mu \mathrm{g} / \mathrm{L}$. For sites with 5 or more samples, 85th percentile concentrations ranged from 7.4 to 108 $\mu \mathrm{g} / \mathrm{L}$ (table 4). All 85th percentile concentrations exceeded the chronic aquatic-life exposure criteria of $4.6 \mu \mathrm{g} / \mathrm{L}$. Mean instantaneous loads, computed using available concentration and instantaneous streamflow pairs, ranged from $0.08 \mathrm{lb} / \mathrm{d}$ at Appleton Drain at River Road to $4.4 \mathrm{lb} / \mathrm{d}$ at Big Salt Wash at Fruita (table 4).

\section{Annual Time-Weighted Mean Selenium Loading Analysis at Tributary Sites}

Mean daily, annual, irrigation season, and nonirrigation season loads and annual load reductions required to meet dissolved selenium water-quality standards were estimated using the ATWM method for Adobe Creek at mouth (USGS 390741108424301), Big Salt Wash at Fruita (USGS 09153270), Leach Creek at Durham (USGS 09152650), Persigo Wash at River Road (USGS 390645108390101), Reed Wash near Loma (USGS 09153300), Reed Wash near Mack (USGS 09153290), and Salt Creek near Mack (USGS 09163490) (table 5). These calculations were made for WYs having adequate data to represent irrigation and nonirrigation season streamflows at each tributary site. At most sites, adequate data were only available during the mid to late 1990s. Dissolved selenium concentrations were higher during nonirrigation season than irrigation season at all sites (table 5). Irrigation season dissolved selenium loads were generally higher than nonirrigation season dissolved selenium loads because streamflows were higher during irrigation season (table 5).

\section{Adobe Creek at Mouth}

Adobe Creek at mouth (USGS 390741108424301) had adequate data to compute loads and load reductions for WY 2001 (National Water Quality Monitoring Council, 2019; U.S. Geological Survey, 2019). The 85th percentile concentration for dissolved selenium was estimated to be $41 \mu \mathrm{g} / \mathrm{L}$ (table 5), about 10 times higher than the water quality standard of 4.6 $\mu \mathrm{g} / \mathrm{L}$ (CDPHE, 2020). The mean dissolved selenium concentration was about 2.5 times higher during nonirrigation season than during irrigation season (table 5). However, the mean daily irrigation season load was more than 4.5 times higher than the mean daily nonirrigation season load, because streamflow was substantially higher during irrigation season than nonirrigation season (table 5). The annual load was estimated to be 580 pounds per year ( $1 \mathrm{~b} / \mathrm{yr}$ ), and the annual load reduction was estimated to be $510 \mathrm{lb} / \mathrm{yr}$ (table 5).

\section{Big Salt Wash at Fruita}

Big Salt Wash at Fruita (USGS 09153270) had continuous streamflow data from 1973 to 1977 , but collection of dissolved selenium data did not start until 1991 (National Water Quality Monitoring Council, 2019; U.S. Geological Survey, 2019). Adequate data were available to compute loads and load reductions for WYs 1996 and 1997. Annual 85th percentile dissolved selenium concentrations ranged from 31 to 43 $\mu \mathrm{g} / \mathrm{L}$ (table 5). Dissolved selenium concentrations measured at Big Salt Wash at Fruita and Adobe Creek at mouth were similar; however, annual dissolved selenium loads were about three times higher at Big Salt Wash at Fruita. The annual dissolved selenium loads were about three times higher, because streamflow was about three times higher at Big Salt Wash at Fruita than Adobe Creek at mouth (table 5). Estimated annual loads ranged from 1,500 to 1,700 lb/yr. Estimated annual load reductions ranged from 1,300 to $1,500 \mathrm{lb} / \mathrm{yr}$ (table 5).

\section{Leach Creek at Durham}

Leach Creek at Durham (USGS 09152650) had continuous streamflow data from 1973 to 1983, but collection of dissolved selenium concentration data did not start until 1991 (National Water Quality Monitoring Council, 2019; U.S. Geological Survey, 2019). Adequate data were available to compute loads and load reductions for WYs 1992, 1995, 1996, 1997, and 1999 (table 5). The mean annual 85th percentile dissolved selenium concentration was $88 \mu \mathrm{g} / \mathrm{L}$, almost 20 times higher than the water quality standard (CDPHE, 2020). Nonirrigation season dissolved selenium concentrations were 
Table 4. Statistical summary of dissolved selenium concentration data for tributary sites on 303(d) listed segments (Colorado Department of Public Health and Environment, 2016) with limited datasets in the Grand Valley, western Colorado, 1991-2018.

[Loads were not computed for sites with less than three concentration and streamflow pairs. $\mu \mathrm{g} / \mathrm{L}$, micrograms per liter; lb/d, pounds per day; NA, no value computed]

\begin{tabular}{|c|c|c|c|c|c|c|c|c|c|}
\hline $\begin{array}{c}\text { Site } \\
\text { name }\end{array}$ & $\begin{array}{c}\text { Site } \\
\text { identifier(s) }\end{array}$ & $\begin{array}{c}\text { Number } \\
\text { of } \\
\text { values }\end{array}$ & $\begin{array}{l}\text { Range } \\
\text { of } \\
\text { sampling } \\
\text { dates }\end{array}$ & $\begin{array}{l}\text { Range of } \\
\text { concentra- } \\
\text { tions }(\mu \mathrm{g} / \mathrm{L})\end{array}$ & $\begin{array}{l}\text { Median } \\
\text { concentra- } \\
\text { tion }(\mu \mathrm{g} / \mathrm{L})\end{array}$ & $\begin{array}{l}\text { 85th } \\
\text { percentile } \\
\text { concentra- } \\
\text { tion }(\mu \mathrm{g} / \mathrm{L})\end{array}$ & $\begin{array}{l}\text { Mean } \\
\text { instan- } \\
\text { taneous } \\
\text { load (lb/d) }\end{array}$ & $\begin{array}{l}\text { Median } \\
\text { instanta- } \\
\text { neous load } \\
\quad(\mathrm{lb} / \mathrm{d})\end{array}$ & $\begin{array}{c}\text { Number of } \\
\text { concentration } \\
\text { and streamflow } \\
\text { pairs used to } \\
\text { calculate mean } \\
\text { load }\end{array}$ \\
\hline $\begin{array}{l}\text { Adobe Creek near mouth at } \\
19 \text { Road }\end{array}$ & $\begin{array}{l}\text { 21COL001_WQX-11133, 21COL001-11133, } \\
\text { 21COL001_WQX-TMDL-AC1, 21COL001_WQX- } \\
\text { TMDL-LC16, USGS-390755108420200 }\end{array}$ & 39 & $\begin{array}{r}01 / 29 / 2005 \text { to } \\
02 / 07 / 2018\end{array}$ & $4.7-44.0$ & 11 & 34.9 & 1.4 & 1.4 & 11 \\
\hline Appleton Drain at River Road & $\begin{array}{l}\text { USGS-390613108380101, 21COL001_WQX-TMDL- } \\
\text { ADT2 }\end{array}$ & 5 & $\begin{array}{r}03 / 21 / 1991 \text { to } \\
06 / 27 / 2017\end{array}$ & $1.9-32.0$ & 2.6 & 27.8 & 0.08 & 0.07 & 4 \\
\hline $\begin{array}{l}\text { Appleton Drain upstream } \\
\text { from Colorado River }\end{array}$ & 21COL001_WQX-TMDL-ADT & 10 & $\begin{array}{r}10 / 14 / 2015 \text { to } \\
02 / 07 / 2018\end{array}$ & $3.0-36.7$ & 9.2 & 23.8 & 0.37 & 0.19 & 5 \\
\hline Big Salt Wash at Fruita & $\begin{array}{l}\text { USGS-09153270, CORIVWCH_WQX-4061, } \\
\text { 21COL001_WQX-TMDL-BSWT2 }\end{array}$ & 47 & $\begin{array}{r}03 / 20 / 1991 \text { to } \\
02 / 07 / 2018\end{array}$ & $4.0-84.0$ & 19.5 & 33.6 & 4.4 & 3.8 & 45 \\
\hline $\begin{array}{l}\text { Big Salt Wash downstream } \\
\text { from I-70 }\end{array}$ & $\begin{array}{l}\text { 21COL001_WQX-TMDL-BSWT, } \\
\text { CORIVWCH_WQX-3263 }\end{array}$ & 9 & $\begin{array}{r}09 / 11 / 2012 \text { to } \\
07 / 17 / 2017\end{array}$ & $8.3-13.9$ & 10.1 & 12.1 & NA & NA & NA \\
\hline Hunter Wash at River Road & CORIVWCH_WQX-4063, USGS-390717108400501 & 18 & $\begin{array}{r}03 / 20 / 1991 \text { to } \\
12 / 06 / 2007\end{array}$ & $6.0-79.0$ & 29.2 & 44 & 1.2 & 0.71 & 15 \\
\hline $\begin{array}{l}\text { Hunter Wash upstream from } \\
\text { Colorado River }\end{array}$ & 21COL001_WQX-TMDL-HWT & 18 & $\begin{array}{r}08 / 08 / 2012 \text { to } \\
02 / 07 / 2018\end{array}$ & $4.6-19.6$ & 6.2 & 9.3 & 0.93 & 0.93 & 6 \\
\hline Indian Wash at C $1 / 2$ Road & USGS-390320108315901, 21COL001_WQX-11135B & 16 & $\begin{array}{r}03 / 21 / 1991 \text { to } \\
06 / 18 / 2012\end{array}$ & $3.4-120$ & 64 & 108 & 0.8 & 0.7 & 6 \\
\hline $\begin{array}{l}\text { Little Salt Wash at Highway } \\
50 \text { at Fruita }\end{array}$ & $\begin{array}{l}\text { USGS-390938108443101, 21COL001_WQX-TMDL- } \\
\text { LSWT, 21COL001_WQX-TMDL-LSWT2 }\end{array}$ & 14 & $\begin{array}{r}03 / 20 / 1991 \text { to } \\
02 / 07 / 2018\end{array}$ & $4.7-24.0$ & 6.7 & 17.2 & 1.4 & 1.5 & 10 \\
\hline Persigo Wash at River Road & USGS-390645108390101 & 19 & $\begin{array}{r}03 / 21 / 1991 \text { to } \\
03 / 07 / 2006\end{array}$ & $7.0-94.1$ & 34 & 70.8 & 2.2 & 1.9 & 19 \\
\hline $\begin{array}{l}\text { Persigo Wash at mouth near } \\
\text { Fruita }\end{array}$ & $\begin{array}{l}\text { 21COL001_WQX-TMDL-PSWT, } \\
\text { USGS-390633108393100 }\end{array}$ & 15 & $\begin{array}{r}11 / 21 / 2004 \text { to } \\
02 / 07 / 2018\end{array}$ & $3.0-14.2$ & 4.9 & 7.4 & 1.1 & 1.1 & 8 \\
\hline $\begin{array}{l}\text { Pritchard Tributary upstream } \\
\text { from Colorado River }\end{array}$ & 21COL001_WQX-TMDL-PRT & 12 & $\begin{array}{r}10 / 14 / 2015 \text { to } \\
02 / 07 / 2018\end{array}$ & $3.6-25.8$ & 8.5 & 17.5 & 0.64 & 0.71 & 7 \\
\hline Pritchard Wash at River Road & USGS-390700108393101 & 3 & $\begin{array}{r}03 / 21 / 1991 \text { to } \\
02 / 03 / 1992\end{array}$ & $12.0-23.0$ & 17 & NA & 0.6 & 0.22 & 3 \\
\hline Reed Wash near Fruita & $\begin{array}{l}\text { 21COL001_WQX-TMDL-RWT1, } \\
\text { USGS-391029108480200 }\end{array}$ & 2 & $\begin{array}{r}03 / 20 / 1991 \text { to } \\
09 / 11 / 2012\end{array}$ & $5.8-120$ & NA & NA & NA & NA & NA \\
\hline
\end{tabular}


Table 5. Selenium loading analysis for sites on 303(d) listed segments (Colorado Department of Public Health and Environment, 2016) using annual time-weighted mean (ATWM) method, Grand Valley, western Colorado.

$\left[\mu \mathrm{g} / \mathrm{L}\right.$, micrograms per liter; lb/d, pounds per day; lb/yr, pounds per year; $\mathrm{ft}^{3} / \mathrm{s}$, cubic feet per second; gray shading indicates mean values for sites with more than one year of data; - , value not computed]

\begin{tabular}{|c|c|c|c|c|c|c|c|c|c|c|c|c|}
\hline $\begin{array}{c}\text { Water } \\
\text { year }\end{array}$ & $\begin{array}{c}\text { Number } \\
\text { of } \\
\text { values }\end{array}$ & $\begin{array}{c}\text { 85th } \\
\text { percentile } \\
\text { concentra- } \\
\text { tion }(\mu \mathrm{g} / \mathrm{L})\end{array}$ & $\begin{array}{l}\text { Mean } \\
\text { daily load } \\
(\mathrm{lb} / \mathrm{d})\end{array}$ & $\begin{array}{c}\text { Annual } \\
\text { load } \\
\text { (lb/yr) }\end{array}$ & $\begin{array}{l}\text { Annual load } \\
\text { reduction } \\
\text { (lb/yr) }\end{array}$ & $\begin{array}{l}\text { Annual load } \\
\text { reduction } \\
\text { (percent) }\end{array}$ & $\begin{array}{c}\text { Non- } \\
\text { irrigation } \\
\text { season } \\
\text { mean } \\
\text { concen- } \\
\text { tration } \\
(\mu \mathrm{g} / \mathrm{L})\end{array}$ & $\begin{array}{c}\text { Non- } \\
\text { irrigation } \\
\text { season } \\
\text { mean } \\
\text { instant- } \\
\text { aneous } \\
\text { stream- } \\
\text { flow }\left(\mathrm{ft}^{3} / \mathrm{s}\right)\end{array}$ & $\begin{array}{c}\text { Non- } \\
\text { irrigation } \\
\text { season } \\
\text { mean daily } \\
\text { load (lb/d) }\end{array}$ & $\begin{array}{l}\text { Irrigation } \\
\text { season } \\
\text { mean } \\
\text { concen- } \\
\text { tration } \\
\text { ( } \mu \mathrm{g} / \mathrm{L})\end{array}$ & $\begin{array}{l}\text { Irrigation } \\
\text { season } \\
\text { mean } \\
\text { instant- } \\
\text { aneous } \\
\text { stream- } \\
\text { flow }\left(\mathrm{ft}^{3} / \mathrm{s}\right)\end{array}$ & $\begin{array}{c}\text { Irrigation } \\
\text { season } \\
\text { mean daily } \\
\text { load }(\mathrm{lb} / \mathrm{d})\end{array}$ \\
\hline \multicolumn{13}{|c|}{ Adobe Creek at mouth } \\
\hline 2001 & 7 & 41 & 1.6 & 580 & 510 & 88 & 37 & 2.8 & 0.58 & 15 & 34 & 2.7 \\
\hline \multicolumn{13}{|c|}{ Big Salt Wash at Fruita } \\
\hline 1996 & 11 & 43 & 4.6 & 1,700 & 1,500 & 88 & 36 & 13 & 2.7 & 13 & 87 & 6.1 \\
\hline 1997 & 10 & 31 & 4.1 & 1,500 & 1,300 & 87 & 22 & 17 & 1.9 & 10 & 103 & 5.9 \\
\hline Mean & - & 37 & 4.4 & 1,600 & 1,400 & 87 & 29 & 15 & 2.3 & 12 & 95 & 6.0 \\
\hline \multicolumn{13}{|c|}{ Leach Creek at Durham } \\
\hline 1992 & 9 & 87 & 3.1 & 1,100 & 1,100 & 100 & 82 & 7.6 & 3.4 & 12 & 40 & 2.5 \\
\hline 1995 & 10 & 86 & 2.7 & 990 & 940 & 95 & 77 & 7.5 & 3.0 & 8.5 & 52 & 2.4 \\
\hline 1996 & 12 & 99 & 3.2 & 1,200 & 1,100 & 92 & 91 & 8.8 & 4.2 & 9.6 & 55 & 2.8 \\
\hline 1997 & 8 & 85 & 2.8 & 1,000 & 980 & 98 & 82 & 7.0 & 3.1 & 9.0 & 54 & 2.6 \\
\hline 1999 & 9 & 85 & 2.7 & 1,000 & 940 & 94 & 85 & 6.9 & 3.1 & 11 & 39 & 2.2 \\
\hline Mean & - & 88 & 2.9 & 1,100 & 1,000 & 96 & 83 & 7.6 & 3.4 & 10 & 48 & 2.5 \\
\hline \multicolumn{13}{|c|}{ Persigo Wash at River Road } \\
\hline 1999 & 9 & 66 & 2.6 & 960 & 900 & 94 & 63 & 4.2 & 1.4 & 16 & 46 & 3.9 \\
\hline \multicolumn{13}{|c|}{ Reed Wash near Loma } \\
\hline 1992 & 13 & 150 & 13.3 & 4,800 & 4,700 & 98 & 126 & 13 & 8.2 & 22 & 147 & 18 \\
\hline 1996 & 12 & 81 & 9.7 & 3,500 & 3,300 & 94 & 75 & 14 & 5.3 & 16 & 146 & 13 \\
\hline 1997 & 12 & 83 & 10.0 & 3,600 & 3,400 & 94 & 76 & 14 & 5.3 & 16 & 147 & 13 \\
\hline Mean & - & 105 & 11.0 & 4,000 & 3,800 & 96 & 92 & 14 & 6.3 & 18 & 147 & 15 \\
\hline \multicolumn{13}{|c|}{ Reed Wash near Mack } \\
\hline 1996 & 14 & 110 & 5.0 & 1,800 & 1,800 & 100 & 100 & 5.8 & 2.8 & 16 & 77 & 6.4 \\
\hline 1997 & 23 & 96 & 4.7 & 1,700 & 1,600 & 94 & 80 & 5.7 & 2.5 & 15 & 68 & 5.7 \\
\hline 1998 & 13 & 92 & 4.9 & 1,800 & 1,700 & 94 & 61 & 32 & 2.6 & 19 & 70 & 6.6 \\
\hline Mean & - & 99 & 4.9 & 1,800 & 1,700 & 96 & 80 & 15 & 2.6 & 17 & 72 & 6.2 \\
\hline \multicolumn{13}{|c|}{ Salt Creek near Mack } \\
\hline 1995 & 10 & 51 & 5.2 & 1,900 & 1,700 & 89 & 45 & 14 & 3.1 & 6.9 & 202 & 7.3 \\
\hline 1996 & 12 & 50 & 6.0 & 2,200 & 2,000 & 91 & 53 & 14 & 4.1 & 8.6 & 164 & 7.3 \\
\hline 1997 & 7 & 43 & 6.1 & 2,200 & 2,000 & 91 & 39 & 15 & 3.1 & 11 & 152 & 8.4 \\
\hline Mean & - & 48 & 5.8 & 2,100 & 1,900 & 90 & 46 & 14 & 3.4 & 8.8 & 173 & 7.7 \\
\hline
\end{tabular}


substantially higher than irrigation season dissolved selenium concentrations (table 5). As a result, nonirrigation season mean daily loads were higher than irrigation season mean daily loads even though streamflows were higher during irrigation season than nonirrigation season (table 5). Annual loads ranged from 990 to $1,200 \mathrm{lb} / \mathrm{yr}$, and percent load reductions ranged from 92 to 100 percent (table 5).

\section{Persigo Wash at River Road}

Persigo Wash at River Road (USGS 390645108390101) had adequate data to compute loads and load reductions for WY 1999 (National Water Quality Monitoring Council, 2019; U.S. Geological Survey, 2019). The annual 85th percentile concentration for dissolved selenium was $66 \mu \mathrm{g} / \mathrm{L}$. The mean dissolved selenium concentration was about four times higher during nonirrigation season than during irrigation season (table 5). The mean instantaneous streamflow during irrigation season was about 11 times higher than the mean instantaneous streamflow during nonirrigation season. The mean irrigation season mean daily load was $3.9 \mathrm{lb} / \mathrm{d}$, and the mean nonirrigation season mean daily load was $1.4 \mathrm{lb} / \mathrm{d}$ (table 5). The annual load was estimated to be $960 \mathrm{lb} / \mathrm{yr}$, and the required load reduction was $900 \mathrm{lb} / \mathrm{yr}$, a load reduction of 94 percent (table 5).

\section{Reed Wash near Loma}

Reed Wash near Loma (USGS 09153300) had continuous streamflow data from 1973 to 1983, but collection of dissolved selenium data did not start until 1991. Adequate data were available to compute loads and load reductions for WYs 1992, 1996, and 1997 (National Water Quality Monitoring Council, 2019; U.S. Geological Survey, 2019). For those 3 years, the mean annual 85th percentile dissolved selenium concentration was estimated to be $105 \mu \mathrm{g} / \mathrm{L}$ (table 5). The mean annual load was estimated to be $4,000 \mathrm{lb} / \mathrm{yr}$, about 2 to 7 times higher than annual loads estimated at other tributary sites using the ATMW method (table 5). The higher mean annual load was likely because streamflows were generally higher at Reed Wash near Loma, especially during irrigation season, than other tributary sites. Only Salt Creek near Mack had comparable irrigation season streamflows, but dissolved selenium concentrations at Salt Creek near Mack were about one-half that of Reed Wash near Loma (table 5).

\section{Reed Wash near Mack}

Reed Wash near Mack (USGS 09153290) had continuous streamflow data from 1975 to 2000, but collection of dissolved selenium data did not start until 1991. Adequate data were available to compute loads and load reductions for WYs 1996, 1997, and 1998 (National Water Quality Monitoring Council, 2019; U.S. Geological Survey, 2019). For those 3 years, the mean annual 85th percentile dissolved selenium concentration was estimated to be $99 \mu \mathrm{g} / \mathrm{L}$. Irrigation season streamflows at Reed Wash near Mack were about one-half as much as irrigation streamflows downstream at Reed Wash near Loma. As a result, dissolved selenium loads were lower at Reed Wash near
Mack than Reed Wash near Loma. The mean annual load was estimated to be $1,800 \mathrm{lb} / \mathrm{yr}$, and the mean annual load reduction was estimated to be $1,700 \mathrm{lb} / \mathrm{yr}$, a mean load reduction of 96 percent (table 5).

\section{Salt Creek near Mack}

Salt Creek near Mack (USGS 09163490) had continuous streamflow data from 1973 to 1983, but collection of dissolved selenium data did not start until 1991 (National Water Quality Monitoring Council, 2019; U.S. Geological Survey, 2019). Adequate data were available to compute loads and load reductions for WYs 1995, 1996, and 1997. For those 3 years, the mean annual 85th percentile dissolved selenium concentration was estimated to be $48 \mu \mathrm{g} / \mathrm{L}$ (table 5 ). The highest irrigation season mean instantaneous streamflows were measured at Salt Creek near Mack. However, the highest annual loads were measured at Reed Wash near Loma because selenium concentrations were higher at Reed Wash near Loma than Salt Creek near Mack (table 5). The mean annual load was estimated to be $2,100 \mathrm{lb} / \mathrm{yr}$, and the mean annual load reduction was estimated to be $1,900 \mathrm{lb} / \mathrm{yr}$, a mean load reduction of 90 percent (table 5).

\section{Load Estimation Using Regression Analysis at Lewis Wash near Grand Junction}

Mean daily, annual, irrigation season, nonirrigation season concentrations, loads, and annual load reductions were estimated using load estimation (R-LOADEST) regression analysis for data collected during WY 2003 for Lewis Wash near Grand Junction. Table 6 shows a summary of the regression model diagnostics. The annual 85th percentile dissolved selenium concentration was $26.6 \mu \mathrm{g} / \mathrm{L}$ (table 7), more than 5.5 times higher than the water-quality standard of $4.6 \mu \mathrm{g} / \mathrm{L}$ (CDPHE, 2020). Dissolved selenium concentrations were much lower in Lewis Wash during irrigation season than during nonirrigation season. The mean dissolved selenium concentration was $1.36 \mu \mathrm{g} / \mathrm{L}$, less than the water-quality standard, during irrigation season and $23.1 \mu \mathrm{g} / \mathrm{L}$ during nonirrigation season (table 7).

The annual and seasonal loads at Lewis Wash near Grand Junction were substantially lower than annual and seasonal loads at other tributary sites estimated using the ATWM method (table 5). The estimated annual load at Lewis Wash near Grand Junction for WY 2003 was 17.9 lb/yr (0.049 lb/d), and the required annual load reduction was $14.8 \mathrm{lb} / \mathrm{yr}$ (table 7). The mean daily irrigation season load was $0.06 \mathrm{lb} / \mathrm{d}$, and the mean daily nonirrigation season load was $0.03 \mathrm{lb} / \mathrm{d}$ (table 7). Annual loads estimated using the ATWM method ranged from 580 to $4,800 \mathrm{lb} / \mathrm{yr}$ (table 5), about 7.5 to 268 times higher than the annual load at Lewis Wash near Grand Junction.

\section{Main-Stem Selenium Loads and Trends}

Regression analysis was used to estimate mean daily dissolved selenium concentrations and loads at the three main-stem sites for WYs 1980-2018 (Gunnison River near Grand Junction and Colorado River near Colorado-Utah State 
[USGS, U.S. Geological Survey; $\mu \mathrm{g} / \mathrm{L}$, micrograms per liter]

\begin{tabular}{|c|c|c|c|c|c|c|c|c|c|}
\hline $\begin{array}{c}\text { Site } \\
\text { name }\end{array}$ & $\begin{array}{c}\text { Site } \\
\text { identifier }\end{array}$ & $\begin{array}{l}\text { Model number } \\
\text { (Runkel and } \\
\text { others, 2004) }\end{array}$ & $\begin{array}{l}\text { Coefficient of } \\
\text { determination } \\
\left(\mathbf{R}^{2}\right)\end{array}$ & p-value & $\begin{array}{l}\text { Residual } \\
\text { variance }\end{array}$ & $\begin{array}{c}\text { Mean stan- } \\
\text { dard error } \\
\text { of estimates } \\
(\mu \mathrm{g} / \mathrm{L})\end{array}$ & $\begin{array}{c}\text { Mean daily } \\
\text { selenium } \\
\text { concentration } \\
(\mu \mathrm{g} / \mathrm{L})\end{array}$ & $\begin{array}{c}\text { Mean } \\
\text { 95-percent } \\
\text { confidence } \\
\text { interval (lower) } \\
(\mu \mathrm{g} / \mathrm{L})\end{array}$ & $\begin{array}{c}\text { Mean } \\
\text { 95-percent } \\
\text { confidence } \\
\text { interval (upper) } \\
(\mu \mathrm{g} / \mathrm{L})\end{array}$ \\
\hline $\begin{array}{l}\text { Lewis Wash near Grand } \\
\text { Junction }\end{array}$ & USGS-09106200 & 4 & 85.3 & $<0.0001$ & 0.107 & 1.68 & 10.4 & 4.37 & 21.6 \\
\hline
\end{tabular}

Table 7. Selenium loading analyses for Lewis Wash near Grand Junction using regression analysis (R_LOADEST) method (Runkel and others, 2004), Grand Valley, western Colorado, 2003.

[USGS, U.S. Geological Survey; $\mu \mathrm{g} / \mathrm{L}$, micrograms per liter; lb/d, pounds per day; lb/yr, pounds per year]

\begin{tabular}{|c|c|c|c|c|c|c|c|c|c|c|c|}
\hline $\begin{array}{c}\text { Site } \\
\text { name }\end{array}$ & $\begin{array}{c}\text { Site } \\
\text { identifier }\end{array}$ & $\begin{array}{l}\text { Water } \\
\text { year }\end{array}$ & $\begin{array}{c}\text { 85th } \\
\text { percentile } \\
(\mu \mathrm{g} / \mathrm{L})\end{array}$ & $\begin{array}{c}\text { Mean } \\
\text { daily load } \\
\text { (lb/d) }\end{array}$ & $\begin{array}{l}\text { Annual } \\
\text { load } \\
\text { (lb/yr) }\end{array}$ & $\begin{array}{c}\text { Annual } \\
\text { Load reduc- } \\
\text { tion (lb/yr) }\end{array}$ & $\begin{array}{l}\text { Percentage } \\
\text { load } \\
\text { reduction } \\
\text { (percent) }\end{array}$ & $\begin{array}{c}\text { Nonirrigation } \\
\text { season mean } \\
\text { concentra- } \\
\text { tion }(\mu \mathrm{g} / \mathrm{L})\end{array}$ & $\begin{array}{l}\text { Nonirrigation } \\
\text { season mean } \\
\text { daily load } \\
\text { (lb/d) }\end{array}$ & $\begin{array}{c}\text { Irrigation } \\
\text { season mean } \\
\text { concentra- } \\
\text { tion }(\mu \mathrm{g} / \mathrm{L})\end{array}$ & $\begin{array}{l}\text { Irrigation } \\
\text { season mean } \\
\text { daily load } \\
\text { (lb/d) }\end{array}$ \\
\hline $\begin{array}{l}\text { Lewis Wash near } \\
\text { Grand Junction }\end{array}$ & USGS-09106200 & 2003 & 26.6 & 0.049 & 17.9 & 14.8 & 83 & 23.1 & 0.03 & 1.36 & 0.06 \\
\hline
\end{tabular}


Line) and WYs 2002-18 (Colorado River near Cameo). Trend analyses of FN estimates of dissolved selenium concentrations and loads for these sites ended in WY 2017. Trend analyses were conducted across the year as well as during the irrigation season (April-October) and nonirrigation season (NovemberMarch). Because irrigation season ends October 31, but a new water year begins October 1, it was not possible to complete trend analyses for WY 2018. Differences between upstream and downstream contributions are used to estimate annual and seasonal contributions of dissolved selenium from the Grand Valley. Data from October were not included in seasonal contributions of dissolved selenium in WY 2018.

\section{Dissolved Selenium Concentrations and Loads at Main-Stem Sites}

Boxplots of dissolved selenium concentrations based on discrete water-quality samples are plotted in an upstream to downstream order for WYs 1980-2018 in figure 6. Dissolved selenium concentrations ranged from 0.3 to $16.4 \mu \mathrm{g} / \mathrm{L}$ across all sites. Colorado River near Cameo had the lowest dissolved selenium concentrations (median across period of record is $0.58 \mu \mathrm{g} / \mathrm{L}$ ), and Gunnison River near Grand Junction had the highest (median across period of record is $4.7 \mu \mathrm{g} / \mathrm{L}$ ) (fig. 6).

Dissolved selenium loads, based on discrete water-quality samples, in pounds per day for the three sites, are shown in figure 7. Dissolved selenium loads were lowest at Colorado River at Cameo (3.06 to $49.2 \mathrm{lb} / \mathrm{d}$ ) and highest at Colorado River near Colorado-Utah State Line (33.0 to $619.2 \mathrm{lb} / \mathrm{d}$ ).

\section{Trend Analysis of Dissolved Selenium Concentrations and Loads at Main-Stem Sites}

Using the WRTDS approach, a trend analysis of FN annual mean dissolved selenium concentrations and loads was completed at the three main-stem sites using water-quality data collected from WY 1980 to WY 2017 (Gunnison River near Grand Junction and Colorado River near Colorado-Utah State Line) and from WY 2002 to WY 2017 (Colorado River near Cameo). Trend analysis was conducted across the entire year as well as during the irrigation season (April-October) and nonirrigation season (November-March).

A continuing downward trend in FN annual mean dissolved selenium concentration was observed at all main-stem sites and across all seasonal designations of the analysis, as indicated in table 8 and figures $8 A-8 E$. The $\mathrm{FN}$ annual mean dissolved selenium concentration decreased by $0.12 \mu \mathrm{g} / \mathrm{L}$ from WY 2002 to 2017 at Colorado River at Cameo, representing a 18-percent decrease during the time period. The FN annual mean dissolved selenium concentration at Gunnison River near Grand Junction decreased by $4.2 \mu \mathrm{g} / \mathrm{L}$ from WY 1980 to 2017, representing a 56-percent decrease overall. Over the same time period, the FN annual mean dissolved selenium concentration at Colorado River near Colorado-Utah State Line decreased by $3.8 \mu \mathrm{g} / \mathrm{L}$, representing a 56-percent decrease overall. Trend slopes and percentage changes were similar among irrigation and nonirrigation time periods at all sites (table 8).
A downward trend in dissolved selenium load was also observed at all sites and across all seasonal designations of the analysis (fig. 8, table 8). The FN annual mean dissolved selenium loads decreased by $1.9 \mathrm{lb} / \mathrm{d}$ at Colorado River near Cameo, a 19-percent decrease from WY 2002 to 2017. The greatest decreases in FN annual mean dissolved selenium loads occurred at Gunnison River near Grand Junction (44 lb/d) and Colorado River near Colorado-Utah State Line $(91 \mathrm{lb} / \mathrm{d})$, representing 57-percent and 55-percent decreases respectively from WY 1980 to 2017 (table 8).

\section{Dissolved Selenium Load Contribution from the Grand Valley}

The relative contribution of dissolved selenium from the Grand Valley near Grand Junction was estimated by comparing loads at sites bracketing the study area (fig. 1). The two upstream sites, Colorado River near Cameo and Gunnison River near Grand Junction, contributed 60,300 cumulative pounds and 251,000 cumulative pounds, respectively, during WYs 2002-18 (table 9). At the farthest downstream site, Colorado River near Colorado-Utah State Line, 490,000 cumulative pounds were estimated during the same time period, indicating that the region between Gunnison River near Grand Junction and State line contributed approximately 179,000 cumulative pounds or a mean annual load of 10,500 lb/yr (table 9). Annual dissolved selenium contributions from the Grand Valley were greater during irrigation months (April through October) compared to nonirrigation months (November through March) (fig. 9).

\section{Dissolved Selenium Loads and Data Gaps in the Grand Valley}

Dissolved selenium data were available for tributary sites on Adobe Creek, Appleton Drain, Big Salt Wash, Hunter Wash, Indian Wash, Leach Creek, Lewis Wash, Little Salt Wash, Persigo Wash, Pritchard Wash, Reed Wash, and Salt Creek (tables 4, 5, and 7). Because 7 of the 12 sites at or near tributary mouths did not have enough streamflow data, annual loads were not computed (Indian Wash at C 1/2 Road, Appleton Drain upstream from Colorado River, Persigo Wash at mouth near Fruita, Pritchard Tributary upstream from Colorado River, Hunter Wash upstream from the Colorado River, Little Salt Wash at Highway 50 at Fruita, and Big Salt Wash at Fruita). Although most of these sites had data collected as recently as 2017 and 2018, some of the samples were older, which may affect the accuracy of this analysis. The six paired concentration and streamflow samples for Indian Wash at C 1/2 Road were all collected between 1991 and 1995, and five of those samples were collected during nonirrigation season. Of the 10 pairs for Little Salt Wash at Highway 50 at Fruita, 3 were collected in 1991 and 1992 (National Water Quality Monitoring Council, 2019; U.S. Geological Survey, 2019). The estimated daily load for Big Salt Wash at Fruita is based on 45 paired samples, 31 of which were collected between 1991 and 1998. 


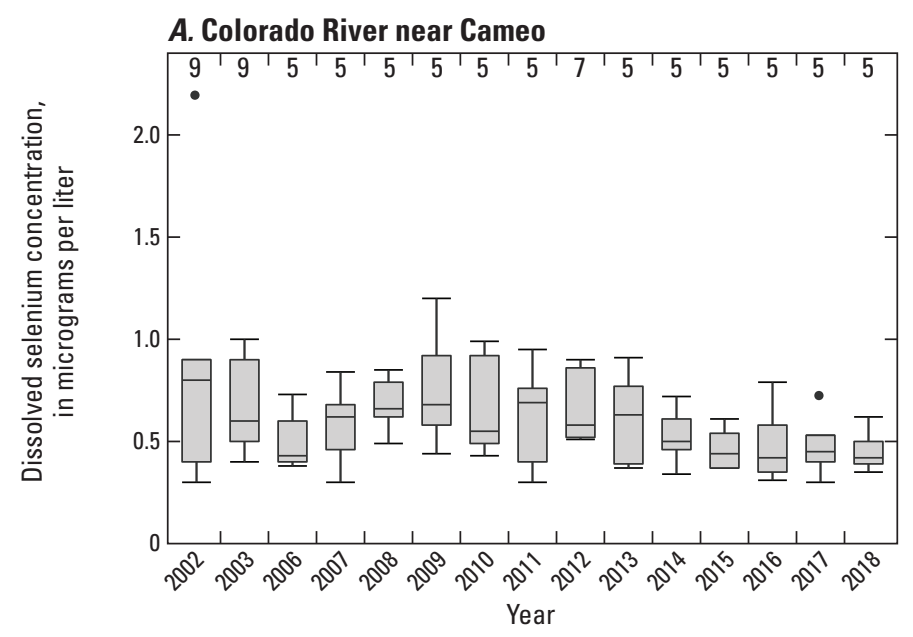

EXPLANATION

5 Number of values

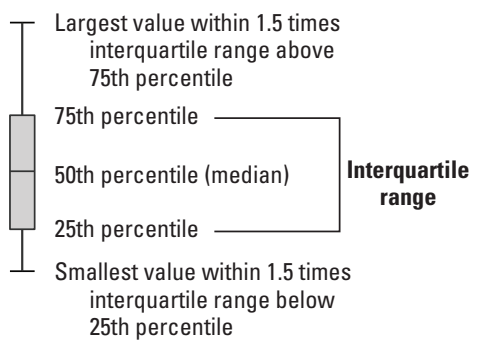

- Outside value-Value is $>1.5$ and $<3$ times the interquartile range above the box

B. Gunnison River near Grand Junction

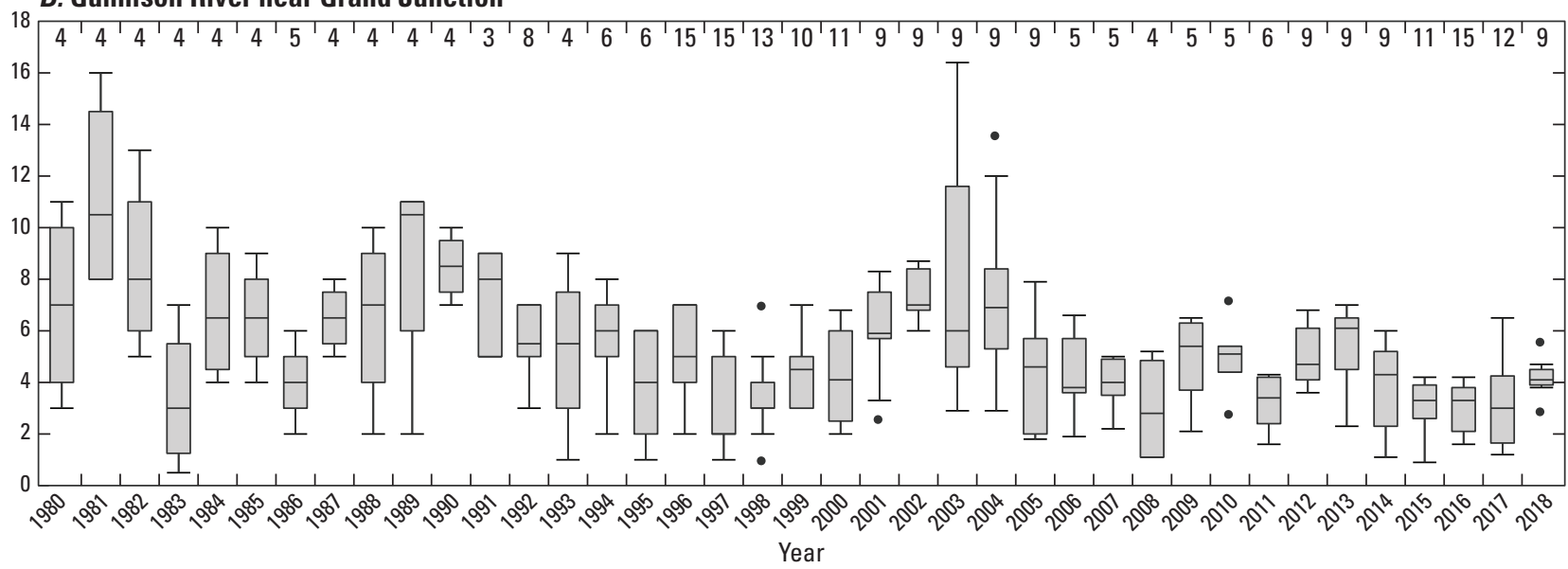

C. Colorado River near Colorado-Utah state line
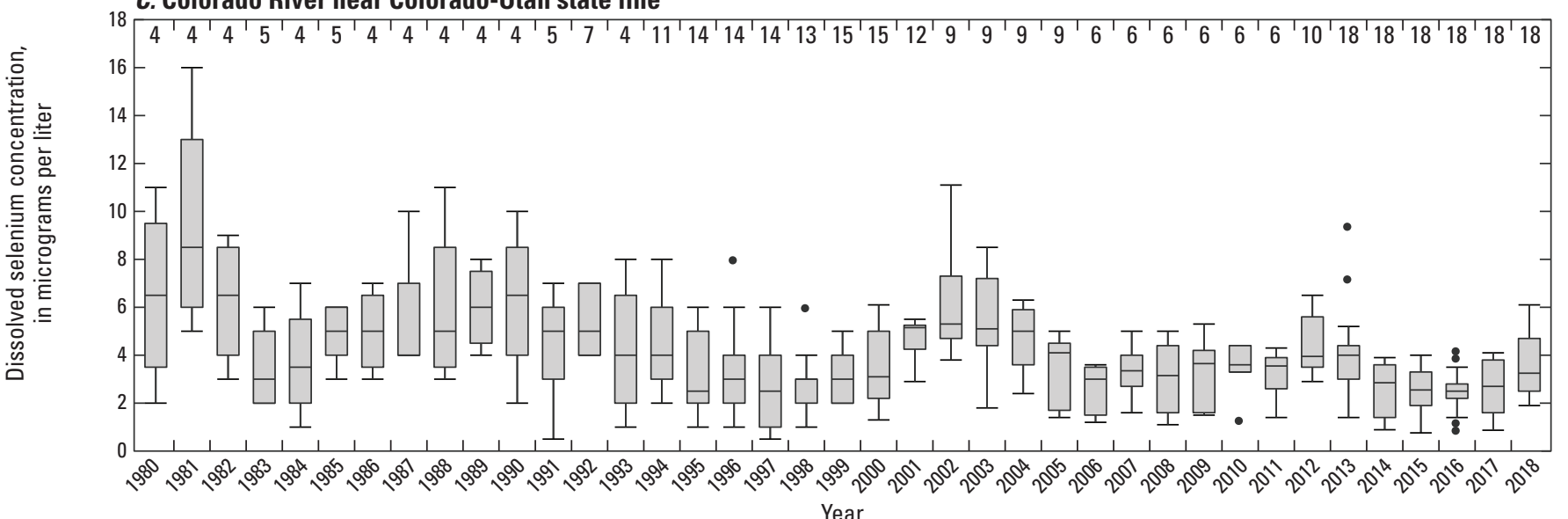

Figure 6. Dissolved selenium concentrations, in micrograms per liter, for discrete water-quality samples at U.S. Geological streamflow-gaging stations $A$, Colorado River near Cameo; $B$, Gunnison River near Grand Junction; and $C$, Colorado River near Colorado-Utah State Line, for water years 1980-2018. 


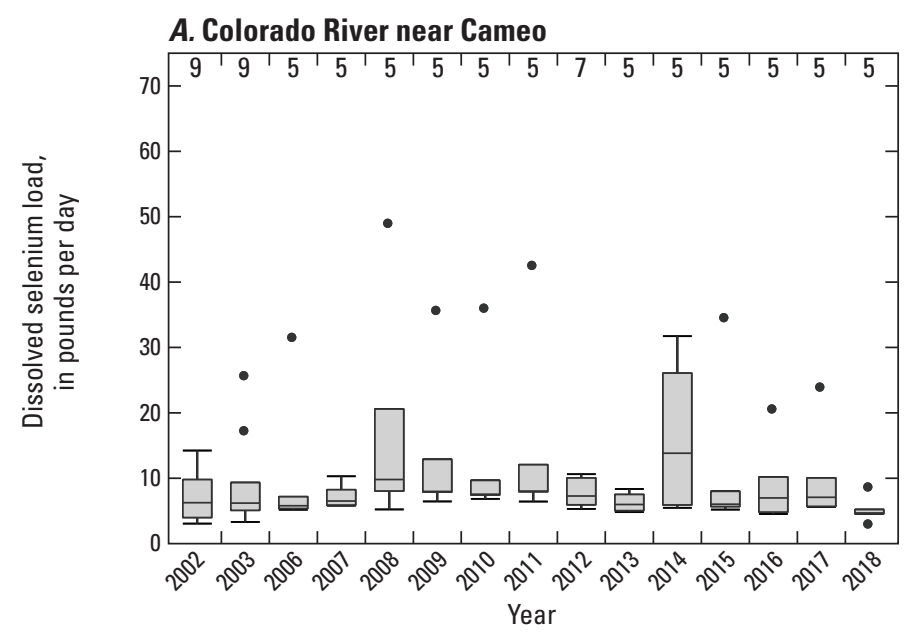

EXPLANATION

5 Number of values

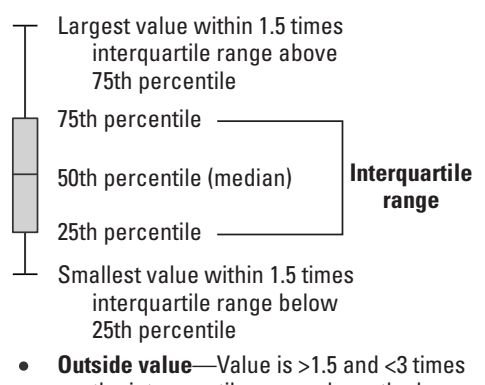
the interquartile range above the box

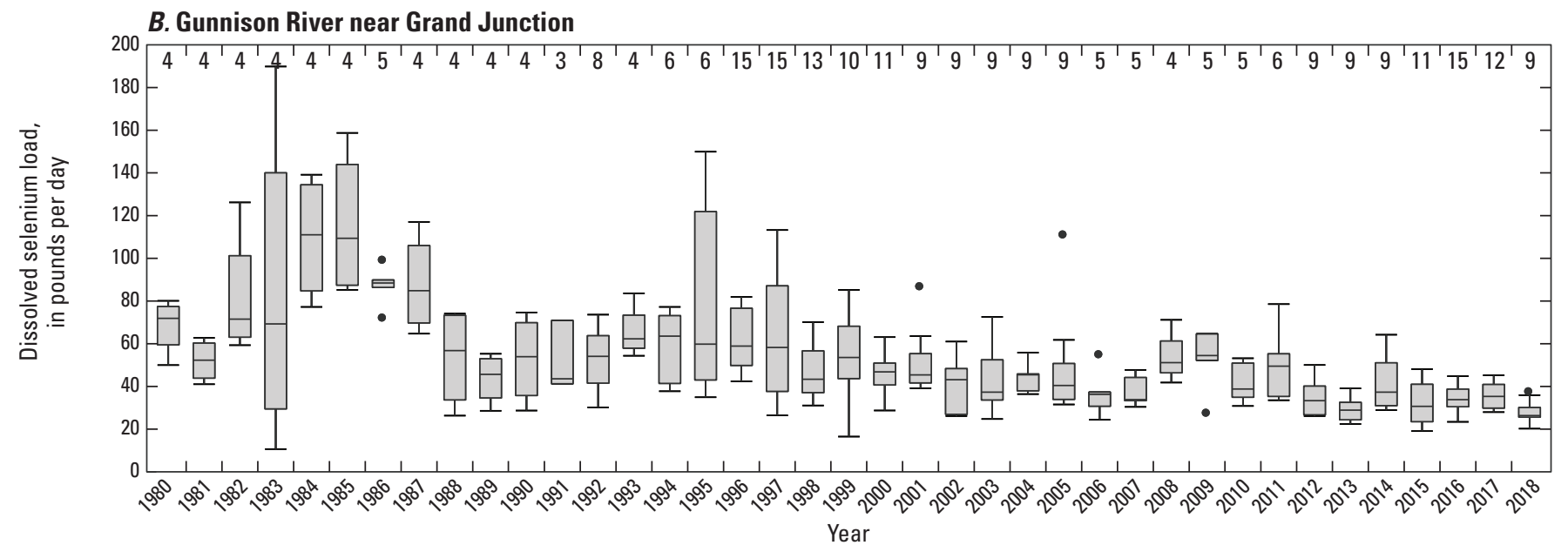

C. Colorado River near Colorado-Utah state line

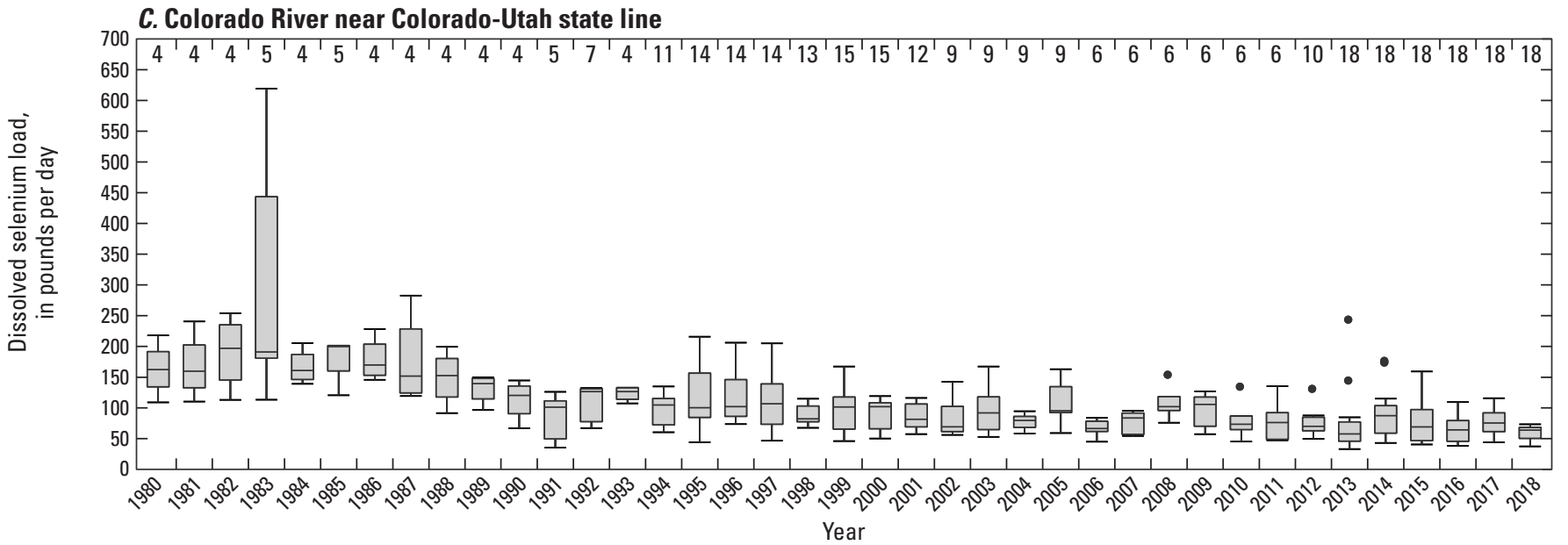

Figure 7. Dissolved selenium loads, in pounds per day, for discrete water-quality samples at U.S. Geological streamflow-gaging stations $A$, Colorado River near Cameo; $B$, Gunnison River near Grand Junction; and C, Colorado River near Colorado-Utah State Line, for water years 1980-2018. 
Table 8. Trends in annual and seasonal dissolved selenium concentrations and loads at selected main-stem U.S. Geological Survey streamflow-gaging stations, Grand Valley, western Colorado, water years 1980-2017.

[Seasons are (1) annual, water year (WY); (2) irrigation, April-October; and (3) nonirrigation, November-March. USGS, U.S. Geological Survey; p-value is a double-sided p-value]

\begin{tabular}{|c|c|c|c|c|c|c|c|c|c|}
\hline $\begin{array}{c}\text { Number } \\
\text { of } \\
\text { samples }\end{array}$ & Season & Measurement & $\begin{array}{l}\text { Trend } \\
\text { slope, } \\
\text { units }\end{array}$ & $\begin{array}{c}\text { Trend slope, } \\
\text { units } \\
\text { per year }\end{array}$ & $\begin{array}{c}\text { Percent } \\
\text { change, } \\
\text { total }\end{array}$ & $\begin{array}{l}\text { Percent } \\
\text { change, } \\
\text { per year }\end{array}$ & p-value & Likelihood & $\begin{array}{c}\text { Trend } \\
\text { direction }\end{array}$ \\
\hline \multicolumn{10}{|c|}{ Colorado River near Cameo (USGS-09095500); WY 2002-17 } \\
\hline \multirow[t]{2}{*}{85} & annual & Concentration, in micrograms per liter & -0.12 & -0.0079 & -18 & -1.2 & 0.067 & 0.972 & downward \\
\hline & & Load, in pounds per day & -1.9 & -0.13 & -19 & -1.3 & 0.055 & 0.972 & downward \\
\hline \multirow[t]{2}{*}{56} & irrigation & Concentration, in micrograms per liter & -0.09 & -0.006 & -16 & -1.1 & 0.062 & 0.972 & downward \\
\hline & & Load, in pounds per day & -2.3 & -0.16 & -19 & -1.3 & 0.048 & 0.991 & downward \\
\hline \multirow[t]{2}{*}{29} & nonirrigation & Concentration, in micrograms per liter & -0.17 & -0.011 & -21 & -1.4 & 0.072 & 0.972 & downward \\
\hline & & Load, in pounds per day & -1.5 & -0.1 & -20 & -1.4 & 0.070 & 0.972 & downward \\
\hline \multicolumn{10}{|c|}{ Gunnison River near Grand Junction (USGS-09152500); WY 1980-2017 } \\
\hline \multirow[t]{2}{*}{285} & annual & Concentration, in micrograms per liter & -4.2 & -0.11 & -56 & -1.5 & 0.05 & 0.988 & downward \\
\hline & & Load, in pounds per day & -44 & -1.2 & -57 & -1.5 & 0.05 & 0.988 & downward \\
\hline \multirow[t]{2}{*}{188} & irrigation & Concentration, in micrograms per liter & -4.2 & -0.11 & -59 & -1.6 & 0.05 & 0.988 & downward \\
\hline & & Load, in pounds per day & -50 & -1.3 & -59 & -1.6 & 0.05 & 0.988 & downward \\
\hline \multirow[t]{2}{*}{97} & nonirrigation & Concentration, in micrograms per liter & -4.2 & -0.11 & -52 & -1.4 & 0.05 & 0.988 & downward \\
\hline & & Load, in pounds per day & -36 & -0.97 & -53 & -1.4 & 0.05 & 0.988 & downward \\
\hline \multicolumn{10}{|c|}{ Colorado River near Colorado-Utah State Line (USGS-09163500); WY 1980-2017 } \\
\hline \multirow[t]{2}{*}{360} & annual & Concentration, in micrograms per liter & -3.8 & -0.1 & -56 & -1.5 & 0.05 & 0.988 & downward \\
\hline & & Load, in pounds per day & -91 & -2.4 & -55 & -1.5 & 0.05 & 0.988 & downward \\
\hline \multirow[t]{2}{*}{234} & irrigation & Concentration, in micrograms per liter & -3.6 & -0.096 & -55 & -1.5 & 0.05 & 0.988 & downward \\
\hline & & Load, in pounds per day & -100 & -2.7 & -54 & -1.5 & 0.05 & 0.988 & downward \\
\hline \multirow[t]{2}{*}{126} & nonirrigation & Concentration, in micrograms per liter & -4.0 & -0.11 & -57 & -1.5 & 0.05 & 0.988 & downward \\
\hline & & Load, in pounds per day & -75 & -2 & -57 & -1.5 & 0.05 & 0.988 & downward \\
\hline
\end{tabular}




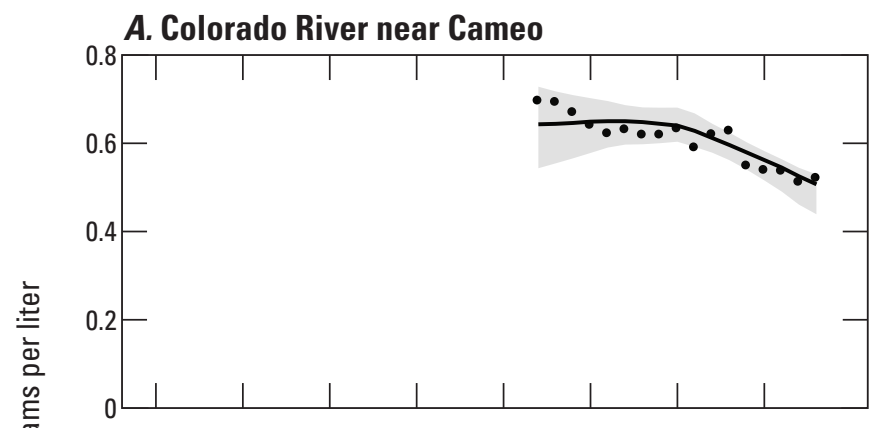

C. Gunnison River near Grand Junction

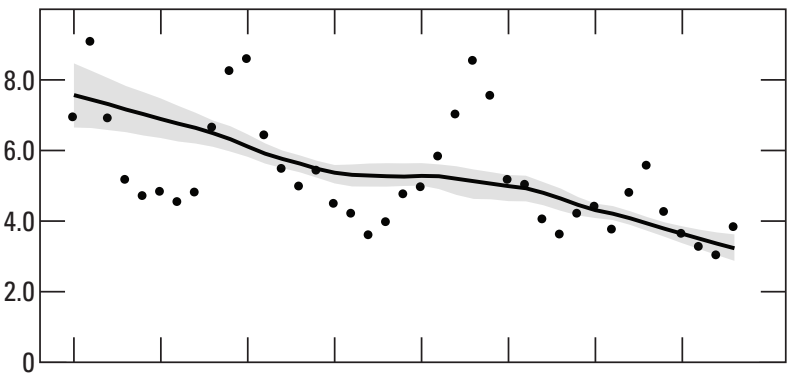

E. Colorado River near Colorado-Utah State Line

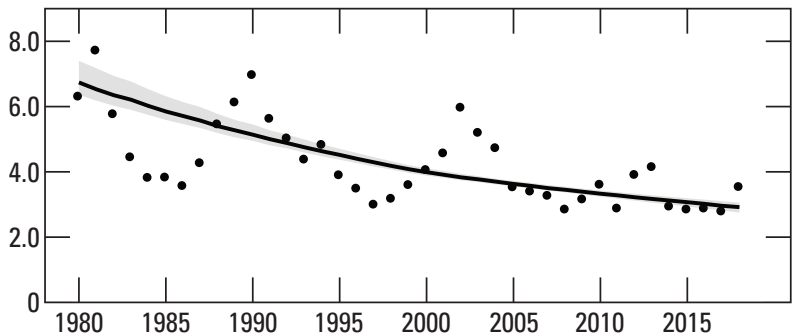

B. Colorado River near Cameo
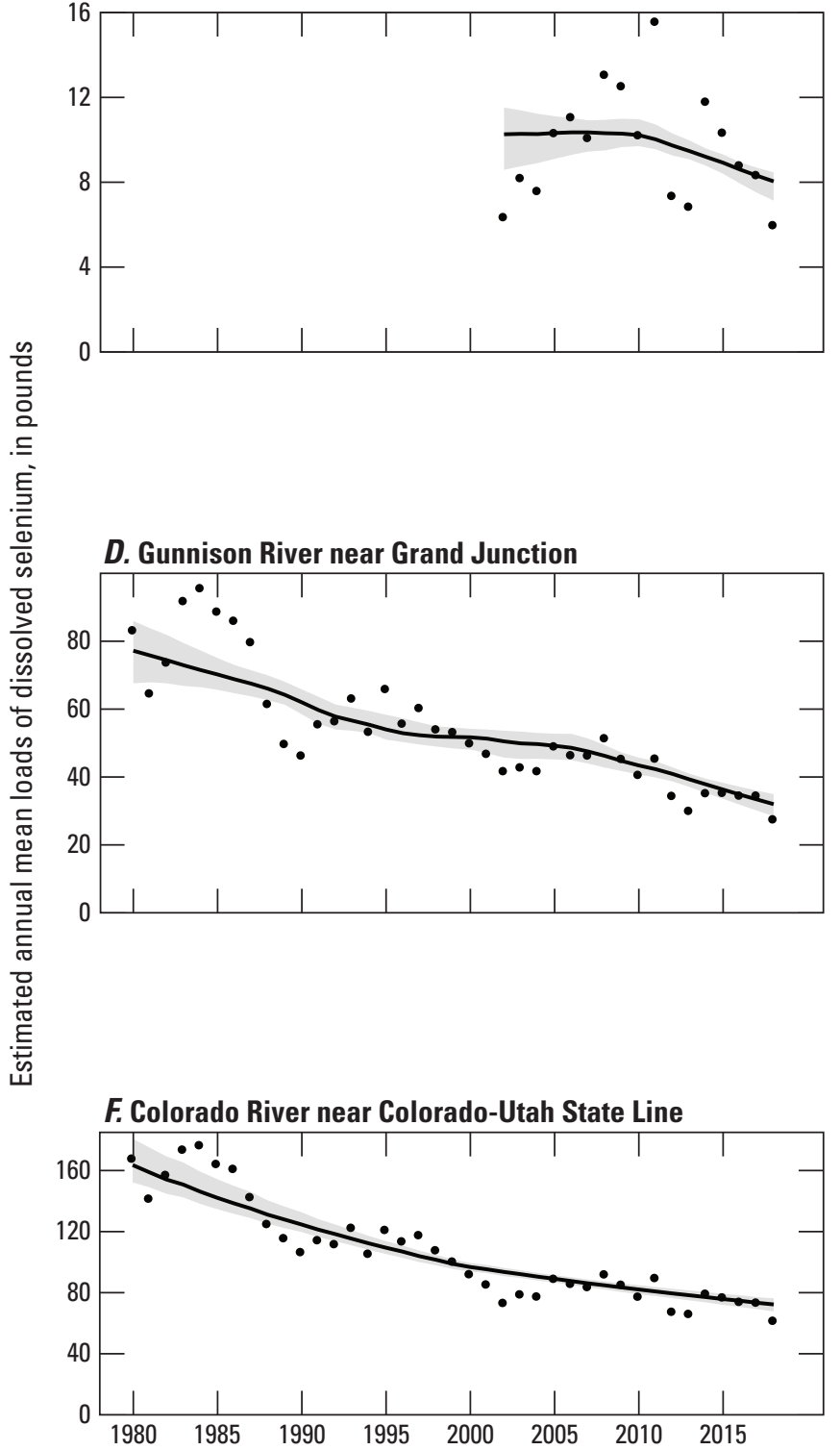

Year

\section{EXPLANATION}

95 percent confidence intervals

Flow-normalized annual mean

concentration or load

- Calculated annual value

Figure 8. Estimated annual mean and flow-normalized annual mean dissolved selenium concentrations and loads at U.S. Geological streamflow-gaging stations $A$ and $B$, Colorado River near Cameo; $C$ and $D$, Gunnison River near Grand Junction and; $E$ and $F$, Colorado River near Colorado-Utah State Line using weighted regressions on time, discharge, and season (WRTDS).

The ATWM method was used to estimate annual loads for four mouth sites: Leach Creek at Durham (annual loads for WYs 1992, 1995, 1996, 1997, and 1999), Adobe Creek at mouth (WY 2001), Reed Wash near Loma (WYs 1992, 1996, and 1997), and Salt Creek near Mack (WYs 1995, 1996, and 1997) (table 5). Only one site, Lewis Wash near
Grand Junction, had enough data for regression analysis with R-LOADEST (table 7). The regression analysis was done for WY 2003 only.

To facilitate comparison with the dissolved selenium loads estimated using the WRTDS method at three mainstem sites bracketing the Grand Valley (table 9), dissolved 
Table 9. Estimated annual dissolved selenium load, in pounds per year, calculated using weighted regressions on time, discharge, and season (WRTDS) at three main-stem U.S. Geological Survey streamflow-gaging stations bracketing the Grand Valley, western Colorado, for water years 2002-18.

[Grand Valley contribution $=$ Colorado River near Colorado-Utah State Line $-($ Colorado River near Cameo + Gunnison River near Grand Junction $]$

\begin{tabular}{ccccc}
\hline \multirow{2}{*}{ Water year } & \multicolumn{4}{c}{ Estimated annual load, in pounds per year } \\
\cline { 2 - 4 } & $\begin{array}{c}\text { Colorado River near } \\
\text { Cameo }\end{array}$ & $\begin{array}{c}\text { Gunnison River near } \\
\text { Grand Junction }\end{array}$ & $\begin{array}{c}\text { Colorado River near } \\
\text { Colorado-Utah State Line }\end{array}$ & $\begin{array}{c}\text { Grand Valley } \\
\text { contribution }\end{array}$ \\
\hline 2002 & 2,330 & 15,300 & 26,900 & 9,280 \\
2003 & 3,010 & 15,700 & 29,000 & 10,300 \\
2004 & 2,790 & 15,400 & 28,600 & 10,400 \\
2005 & 3,780 & 18,000 & 32,700 & 11,000 \\
2006 & 4,050 & 17,000 & 31,500 & 10,500 \\
2007 & 3,700 & 17,000 & 30,800 & 10,100 \\
2008 & 4,800 & 18,900 & 33,900 & 10,200 \\
2009 & 4,590 & 16,700 & 31,300 & 10,100 \\
2010 & 3,750 & 15,000 & 28,500 & 9,800 \\
2011 & 5,700 & 16,700 & 32,900 & 10,500 \\
2012 & 2,710 & 12,700 & 24,900 & 9,540 \\
2013 & 2,520 & 11,100 & 24,400 & 10,800 \\
2014 & 4,320 & 13,000 & 29,200 & 11,900 \\
2015 & 3,790 & 13,000 & 28,300 & 11,500 \\
2016 & 3,240 & 12,700 & 27,300 & 11,300 \\
2017 & 3,060 & 12,700 & 27,000 & 11,300 \\
2018 & 2,200 & 10,200 & 22,700 & 10,400 \\
\hline Maximum annual load & 60,300 & 251,000 & 490,000 & 179,000 \\
\hline
\end{tabular}

selenium loads for 12 tributary sites at or near the mouths were summed to estimate a cumulative load (table 10). The estimated annual load for WY 2003 at Lewis Wash near Grand Junction (table 7) was used in the computation of cumulative load. For sites that had enough data for load estimation using the ATWM method, the mean of the ATWM loads was used in the computation of cumulative load (table 5). For sites that did not have enough data to estimate annual loads for one or more water years, the mean instantaneous load (pounds per day) was multiplied by 365.25 to obtain a dissolved selenium load in $\mathrm{lb} / \mathrm{yr}$ (table 4). The cumulative mean selenium load of the 12 tributaries was approximately 11,300 lb/yr (table 10). According to the results of the trend analysis for selenium loads at the three main-stem sites, the estimated Grand Valley dissolved selenium contribution in WY 2018 was 10,400 lb/yr (table 9), less than the cumulative amount estimated for the 12 tributaries. The estimate of $10,400 \mathrm{lb} / \mathrm{yr}$ includes selenium input from all streams in the Grand Valley, not just the
12 tributaries listed in table 10. This value also includes inputs to the Colorado River from groundwater, which can be a diffuse source of selenium to surface water as deep percolation of irrigation water leaches selenium and other trace elements from soil (Thomas and others, 2019). Therefore, the selenium contribution of the 303(d) listed tributaries are expected to be a portion of the total amount estimated for the Grand Valley.

The load estimates for the tributaries could be improved by more recent data that better represent current conditions. The WRTDS analysis indicates a downward trend in selenium loads for the three main-stem sites between WYs 1980 and 2017 (Gunnison River near Grand Junction and Colorado River near Colorado-Utah State Line) and WYs 2002 and 2017 (Colorado River near Cameo) (table 8). Others have also documented a downward trend in selenium loads in the Colorado and Gunnison Rivers (Mayo and Leib, 2012; Henneberg, 2016). Beginning in 1979, the U.S. Department of Agriculture completed on-farm work to improve irrigation 


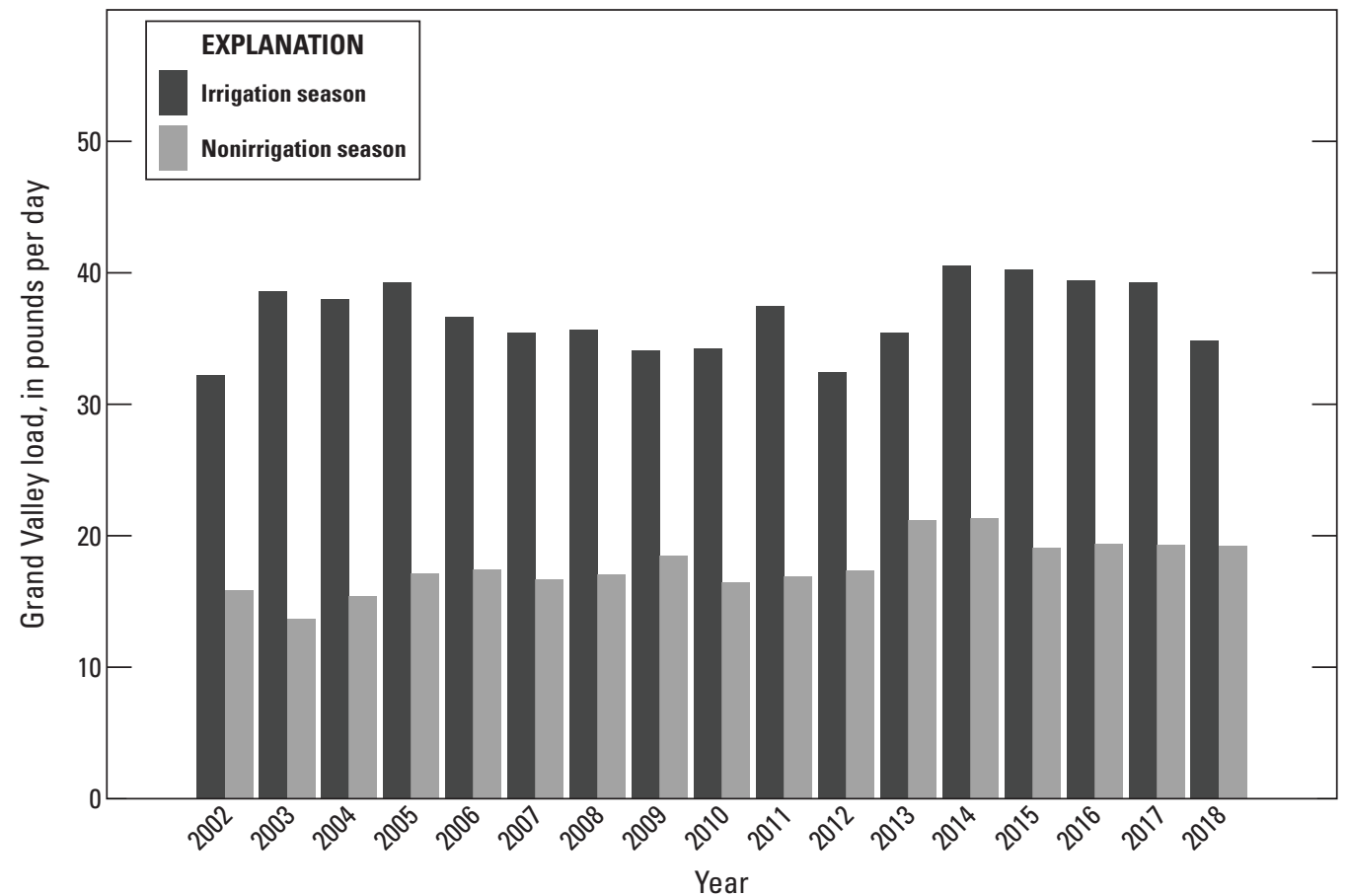

Figure 9. Estimated annual contribution of dissolved selenium load, in pounds per day, from the Grand Valley, western Colorado, for water years 2002-18.

Table 10. Summary of values used to estimate a cumulative dissolved selenium load for tributaries to the Colorado River in the Grand Valley, western Colorado.

[Annual load estimated using the load estimating software R-LOADEST shown in table 7, R-LOADEST; annual load estimated using mean of the annual timeweighted mean method loads in table 5, Mean ATWM; annual load estimated using the mean instantaneous load in pounds per day shown in table 4 multiplied was by 365.25 days, Mean Inst; water year, WY; pounds per day, lb/d; pounds per year, lb/yr]

\begin{tabular}{lcl}
\hline \multicolumn{1}{c}{$\begin{array}{c}\text { Site } \\
\text { name }\end{array}$} & $\begin{array}{c}\text { Estimated mean } \\
\text { annual dissolved } \\
\text { selenium load (lb/yr) }\end{array}$ & Annual load \\
estimation method \\
\hline Adobe Creek at mouth & 580 & Mean ATWM WY 2001 (table 5) \\
Appleton Drain upstream from Colorado River & 135 & Mean Inst (table 4) \\
Big Salt Wash at Fruita & 1,600 & Mean ATWM WYs 1996 and 1997 (table 5) \\
Salt Creek near Mack & 2,100 & Mean ATWM WYs 1995, 1996, 1997 (table 5) \\
Hunter Wash upstream from Colorado River & 340 & Mean Inst (table 4) \\
Indian Wash at C 1/2 Road & 292 & Mean Inst (table 4) \\
Leach Creek at Durham & 1,100 & Mean ATWM WYs 1992, 1995, 1996, 1997, and 1999 (table 5) \\
Lewis Wash near Grand Junction & 17.9 & R-LOADEST WY 2003 (table 7) \\
Little Salt Wash at Highway 50 at Fruita & 511 & Mean Inst (table 4) \\
Persigo Wash at mouth near Fruita & 402 & Mean Inst (table 4) \\
Pritchard Tributary upstream from Colorado River & 234 & Mean Inst (table 4) \\
Reed Wash near Loma & 4,000 & Mean ATWM WYs 1992, 1996, and 1997 (table 5) \\
\hline Estimated cumulative load & 11,300 & \\
\hline
\end{tabular}


systems and reduce salinity loading to the Colorado River (McBee and others, 2011). In the 1980s and 1990s, the Bureau of Reclamation completed salinity control projects, including canal lining and piping work, in the Grand Valley and the lower Gunnison River Basin (Butler, 1996). Through grants awarded to the Grand Valley Irrigation Company, the Bureau of Reclamation has funded additional canal lining work from 2011 to the present (Bureau of Reclamation, 2017; Rare Earth Science, LLC, 2017). Butler and others (1996) found that selenium and dissolved-solids (salinity) loads in the Grand Valley were correlated, indicating that salinity control projects can also reduce selenium loads. Additionally, the conversion of irrigated agricultural land to urban development in the Grand Valley has led to decreases in irrigation water application, deep percolation, and salt delivery (Mayo, 2008). In Montrose Arroyo in the lower Gunnison River Basin, salinity and dissolved selenium loads were found to have decreased after implementation of a salinity and selenium control project in the late 1990s and conversion of agricultural land to urban development in the 1990s and mid-2000s (Butler, 2001; Richards and Moore, 2015). Given the salinity control projects and land-use change in the Grand Valley as well as the ongoing trend of decreasing selenium loads at the main-stem Colorado River and Gunnison River sites, the current cumulative selenium load of Grand Valley tributaries is likely less than the estimated $11,300 \mathrm{lb} / \mathrm{yr}$. A major data gap in the current study is the lack of instantaneous streamflow measurements concurrent with water-quality samples. For the sites with enough data to compute annual loads, many of the paired concentration and streamflow values were from the 1990s and early 2000s (table 5). Although samples were collected at some sites in 2017 and 2018, only one sample was collected during nonirrigation season (when dissolved selenium concentrations are highest) at each site. As a result, there were not enough samples to represent seasonal variability within a water year; thus, annual loads were not computed for those years.

Dissolved selenium concentrations and loads often differ between irrigation and nonirrigation seasons. Most of the streamflow in tributaries in the Grand Valley is irrigation water, and most of the tributaries are ephemeral upgradient from the Government Highline Canal. Streamflow increases significantly during irrigation season and decreases during nonirrigation season (Leib, 2008). High streamflows can dilute concentrations but cause loads to increase. For Leach Creek and Lewis Wash, the daily selenium loads for irrigation and nonirrigation seasons were not substantially different (tables 5 and 7); however, land use in these two drainage areas is largely urban and residential (Leib, 2008). Agricultural land use is more prevalent in the Persigo Wash, Adobe Creek, Big Salt Wash, Reed Wash, and Salt Creek drainage basins (Leib, 2008), and irrigation season daily loads computed for these tributaries were nearly always higher than nonirrigation season daily loads (table 5). Samples would be beneficial during irrigation season when loads tend to be higher and during transition periods when concentrations and loads can vary depending on when irrigation water is turned on or off. In the current study, the ATWM method was used to compute annual and seasonal loads for WYs with at least seven samples that adequately represented seasonal variability. A WY was proportionately represented if samples were collected during irrigation and nonirrigation season at relatively regular intervals. The dissolved selenium load estimates computed for this study could be improved by a monitoring strategy that ensures the number and seasonal distribution of samples are adequate to proportionally represent wet and dry periods, thus enabling calculation of more accurate annual loads.

Collection of samples during both wet and dry years to account for annual variation is important, because concentrations can be diluted during wet periods and increase during dry periods. Loads can be higher during wet years when streamflow is high and lower during dry years when streamflow is low. For example, drought conditions in 2002 (Leib, 2008) likely contributed to estimated dissolved selenium loads at the three main-stem sites being lower in 2002 than in 2003 (table 9). Including data for wet, dry, and mean years helps to ensure that a load estimate represents the mean condition of the stream. If streamflow data are available, a flow-duration curve can be a useful tool for understanding the range of observed streamflows at a site and comparing annual loads for years with different mean streamflow values (Searcy, 1959).

Another important consideration for future monitoring is the location of sample sites. Dissolved selenium loads generally increase downstream; however, streamflows in the Grand Valley tributaries are complicated by the irrigation system deliveries at different points on the streams. The Grand Valley tributaries are not only used for drainage, but also act as a conveyance system for irrigation water in some cases. Adding to the complexity is the presence of an urban runoff drainage network that drains to the tributaries after storms (City of Grand Junction, 2016; Mesa County, 2020). These inputs can contribute additional selenium, streamflow volume, and other constituents to the tributaries and make it difficult to determine sources. As a result of the many possible inputs to each of the drains in the Grand Valley, streamflow and concentration measurements made at one tributary site may differ substantially from measurements made at nearby upstream or downstream sites. Sites at or near the mouth of a tributary generally represent the cumulative contribution of the stream. However, sample data at these sites may not necessarily be representative of concentration and load values defined by drainage area alone. This condition is primarily a factor from April through October during the irrigation season or during rainfall runoff and snowmelt. 


\section{Summary}

Select tributaries to the Colorado River in the Grand Valley (segment COLCLC13b) have been placed on the State of Colorado 303(d) list as impaired for Escherichia coli (E. coli), total recoverable iron, and dissolved selenium. The Colorado Department of Public Health and Environment Water Quality Control Division is required to develop total maximum daily loads for these constituents in the impaired segment. A study was conducted by the U.S. Geological Survey (USGS), in cooperation with the Grand Valley Drainage District and Colorado Water Conservation Board to (1) characterize concentrations, stream loading, and load reductions for $E$. coli, total recoverable iron, and dissolved selenium using existing data collected from 1980 through 2018 and (2) to identify water-quality data gaps to inform future monitoring strategies. This report provides information on streamflow, constituent concentrations, and loads for E. coli, total recoverable iron, and dissolved selenium for 29 sites on tributaries to the Colorado River identified in stream subsections COLCLC13b_A, COLCLC13b_B, and COLCLC13b_C as well as two sites on the Colorado River; Colorado River near Cameo (USGS 09095500), and Colorado River near Colorado-Utah State Line (USGS 09163500), and one site on the Gunnison River, Gunnison River near Grand Junction (USGS 09152500).

The type and period of data collected at each site varied considerably, thus restricting the ability to assess seasonal and temporal variability in concentrations and calculate loads at some sites. Because limited streamflow data were concurrent with $E$. coli and total recoverable iron concentrations, only instantaneous loads were computed. Adequate data were available to compute dissolved selenium loads and load reductions at select sites.

Seasonal differences in streamflow values occur. At mainstem sites, the highest streamflows were measured during the early summer months of May and June as a result of snowmelt runoff, and the lowest streamflows were measured during the cool winter months, typically January and February. At tributary sites, the highest streamflows were measured during the irrigation season from April to October when streamflows were dominated by irrigation supply water.

Samples were analyzed at five sites along Adobe Creek and at six sites along Leach Creek, the two tributaries in the study area that are impaired for E. coli. For the purposes of this report, a geometric mean was computed for each site using all concentration data. All geometric mean E. coli concentrations at sites along Adobe Creek and Leach Creek exceeded the State recreational use standard of 126 colony forming units per 100 milliliters (CFU/100 mL). E. coli concentrations were generally higher in Adobe Creek than in Leach Creek. Continuous streamflow data were not available; however, four sites (Adobe Creek at K Road, Adobe Creek near mouth at 19 Road, Leach Creek at Summer Hill Drive, Leach Creek at G Road and 25 Road upstream side of turnabout) had instantaneous streamflow measurements that were concurrent with samples collected in 2016 and 2017. Mean instantaneous $E$. coli loads were computed for these sites, but annual loads were not calculated, because the streamflow data were not adequate to represent seasonal variability within a water year. Thus, load reductions were not evaluated.

In Adobe Creek, E. coli concentrations in samples ranged from 45.7 to more than 2,420 CFU/100 mL, and geometric mean concentrations at sites ranged from 301 to 1,180 CFU/100 mL. The E. coli concentrations generally increased in the downstream direction in Adobe Creek; however, increases were not seen between all sites. The largest downstream increase in $E$. coli concentration was measured between the two most upstream sites. The median instantaneous streamflow and median load more than doubled between Adobe Creek at K Road (AC3) and Adobe Creek near mouth at 19 Road (AC1) increasing from 13.8 to 29.6 cubic feet per second ( $\left.\mathrm{ft}^{3} / \mathrm{s}\right)$ and 252 to 538 billion colonyforming units per day, respectively.

In Leach Creek, concentrations of E. coli in samples ranged from 25.9 to more than 2,420 CFU/100 mL, and geometric mean concentrations at sites ranged from 160 to 259 CFU/100 mL. The E. coli concentrations showed no consistent downgradient increase in Leach Creek. In fact, some of the highest $E$. coli concentrations were measured at the most upstream site, Leach Creek at Summer Hill Drive (LC6). The median instantaneous streamflow and median E. coli load increased from 0.21 to $12.4 \mathrm{ft}^{3} / \mathrm{s}$ and 0.64 to 96 billion colony-forming units per day between Leach Creek at Summer Hill Drive (LC6) and Leach Creek at G Road and 25 Road upstream side of turnabout (LC3).

Different types of land use may be responsible for the observed variations in E. coli concentration. There is more residential and urban development in the lower portions of the Adobe Creek and Leach Creek drainage areas and more agricultural land use in the upper portions; however, residential development in the Grand Valley is increasing. Sources of $E$. coli to Adobe and Leach Creeks could include livestock in agricultural areas and urban runoff and septic systems in residential areas.

Total recoverable iron concentrations and loads were evaluated at 15 tributary sites for samples collected from August 1993 to February 2018. Sites were located on Adobe Creek, Appleton Drain, Big Salt Wash, Hunter Wash, Indian Wash, Leach Creek, Lewis Wash, Little Salt Wash, Persigo Wash, Pritchard Wash, Reed Wash, and Salt Creek. Median total recoverable iron concentrations ranged from 211 to 4,670 micrograms per liter $(\mu \mathrm{g} / \mathrm{L})$. The chronic aquatic-life water-quality standard $(1,000 \mu \mathrm{g} / \mathrm{L})$ was exceeded in most irrigation season samples but was rarely exceeded in nonirrigation season samples. Concentrations were often an order of magnitude higher in samples collected during irrigation season than in samples collected during nonirrigation season. As with $E$. coli, the lack of concurrent total recoverable iron and streamflow information is a data gap. None of the sites had enough streamflow data to compute annual loads. Collection of additional concentration and streamflow pairs could improve the estimates of mean instantaneous loads and enable 
calculation of daily loads, annual loads, and load reductions, if the data adequately represent seasonal variability within a water year.

Dissolved selenium concentrations and loads were evaluated at 20 tributary sites and three main-stem sites-Colorado River near Cameo (USGS 09095500), Gunnison River near Grand Junction (USGS 09152500), and Colorado River near Colorado-Utah State Line (USGS 09163500). At the three main-stem sites, regression analysis was used to estimate daily dissolved selenium concentrations and loads for water years (WYs) 1980-2018. A trend analysis of annual dissolved selenium concentrations and loads was conducted across the entire year as well as during irrigation season (April-October) and nonirrigation season (November-March). Seasonal trends could not be calculated across the entire period of analysis due to issues with overlapping water years; therefore, all trend analyses ended in WY 2017. Tributary sites were located on Adobe Creek, Appleton Drain, Big Salt Wash, Hunter Wash, Indian Wash, Leach Creek, Lewis Wash, Little Salt Wash, Persigo Wash, Pritchard Wash, Reed Wash, and Salt Creek. Only eight tributary sites had adequate data available to compute annual and seasonal loads and annual load reductions for one or more WYs. Dissolved selenium concentrations were higher during nonirrigation season than irrigation season at all sites. Irrigation season selenium loads were generally higher than nonirrigation selenium loads because streamflows were higher during irrigation season.

At main-stem sites, dissolved selenium concentrations ranged from 0.3 to $16.4 \mu \mathrm{g} / \mathrm{L}$. Colorado River near Cameo had the lowest dissolved selenium concentrations (median across period of record is $0.58 \mu \mathrm{g} / \mathrm{L}$ ) and Gunnison River near Grand Junction, had the highest (median across period of record is $4.7 \mu \mathrm{g} / \mathrm{L}$ ). Dissolved selenium loads were lowest at Colorado River near Cameo, and highest at Colorado River near Colorado-Utah State Line. A continuing downward trend in dissolved selenium concentration was observed at all sites and across all seasonal designations of the analysis. The dissolved selenium concentration decreased by $0.12 \mu \mathrm{g} / \mathrm{L}$ from WY 2002 to 2017 at Colorado River near Cameo, representing a 18-percent decrease during the time period. The dissolved selenium concentration at Gunnison River near Grand Junction decreased by $4.2 \mu \mathrm{g} / \mathrm{L}$ from WY 1980 to 2017, representing a 56-percent decrease overall. During the same time period, dissolved selenium concentration at Colorado River near Colorado-Utah State Line decreased by $3.8 \mu \mathrm{g} / \mathrm{L}$, representing a 56-percent decrease overall. A downward trend in dissolved selenium load was also observed at all sites and across all seasonal designations of the analysis. Dissolved selenium loads decreased by 1.9 pounds per day $(\mathrm{lb} / \mathrm{d})$ at Colorado River near Cameo, a 19-percent decrease from WY 2002 to 2017. The greatest decreases in dissolved selenium loads occurred at Gunnison River near Grand Junction (44 lb/d), and Colorado River near Colorado-Utah State Line $(91 \mathrm{lb} / \mathrm{d})$, representing 57 - and 55-percent decreases, respectively, from WY 1980 to 2017.
The relative contribution of dissolved selenium from the Grand Valley near Grand Junction was estimated by comparing loads at sites bracketing the study area. The two upstream sites, Colorado River near Cameo and Gunnison River near Grand Junction, contributed 60,300 and 251,000 cumulative pounds, respectively, during WYs 2002-18. At the farthest downstream site, Colorado River near Colorado-Utah State Line, 490,000 cumulative pounds were estimated during the same time period, indicating that the region between Whitewater and State line contributed approximately 179,000 cumulative pounds or a mean annual load of 10,500 pounds per year (lb/yr). Dissolved selenium contributions from the Grand Valley were greater during irrigation months (April through October) compared to nonirrigation months (November through March). Grand Valley dissolved selenium contributions appear to be stable during WYs 2002-18.

The cumulative annual dissolved selenium contribution of the tributaries was estimated by adding the mean loads computed for 12 sites that are at or near the mouth of a tributary. The cumulative mean dissolved selenium load of the 12 tributaries was approximately $11,300 \mathrm{lb} / \mathrm{yr}$. The estimated Grand Valley dissolved selenium contribution in WY 2018 was $10,400 \mathrm{lb} / \mathrm{yr}$, less than the cumulative amount estimated for the 12 tributaries. The estimate of 10,400 lb/yr includes selenium input from all streams in the Grand Valley, not only the 12 tributaries listed in the Dissolved Selenium Loads and Data Gaps in the Grand Valley section of this report. This value also includes inputs to the Colorado River from groundwater, which can be a diffuse source of selenium to surface water as deep percolation of irrigation water leaches selenium and other trace elements from soil.

The load estimates for the tributaries could be improved by more recent data that better represent current conditions and seasonal and annual variability. Most of the streamflow in tributaries in the Grand Valley is irrigation water, and most of the tributaries are ephemeral upgradient from the Government Highline Canal. Samples would be beneficial during irrigation season when loads tend to be higher and during transition periods when concentrations and loads can vary depending on when irrigation water is turned on or off. Similarly, it would be important to collect samples during both wet and dry years to account for annual variation. Concentrations can be diluted during wet periods and increase during dry periods. Loads can be higher during wet years when streamflow is high and lower during dry years when streamflow is low. 


\section{References Cited}

American Public Health Association, American Water Works Association, and Water Environment Federation, 2018, 9223 Enzyme Substrate Coliform Test: Standard methods for the examination of water and wastewater (23rd ed.): Washington, D.C., American Public Health Association, accessed February 24, 2020 at https://www. standardmethods.org/doi/full/10.2105/SMWW.2882.194.

Bureau of Reclamation, 2017, Quality of water Colorado River Basin, progress report no. 25: Bureau of Reclamation, 124 p., accessed March 11, 2020, at https://www.usbr.gov/ uc/progact/salinity/pdfs/PR25final.pdf.

Butler, D.L., 1996, Trend analysis of selected water-quality data associated with salinity-control projects in the Grand Valley, in the Lower Gunnison River Basin, and at Meeker Dome, western Colorado: U.S. Geological Survey WaterResources Investigations Report 95-4274, 38 p., accessed March 3, 2020, at https://doi.org/10.3133/wri954274.

Butler, D.L., 2001, Effects of piping irrigation laterals on selenium and salt loads, Montrose Arroyo Basin, western Colorado: U.S. Geological Survey Water-Resources Investigations Report 01-4204, 14 p., accessed March 3, 2020, at https://doi.org/10.3133/wri014204.

Butler, D.L., Wright, W.G., Stewart, K.C., Osmundson, B.C., Krueger, R.P., and Crabtree, D.W., 1996, Detailed study of selenium and other constituents in water, bottom sediment, soil, alfalfa, and biota associated with irrigation drainage in the Uncompahgre Project Area and in the Grand Valley, west-central Colorado, 1991-93: U.S. Geological Survey Water-Resources Investigations Report 96-4138, 136 p.

City of Grand Junction, 2016, Stormwater: City of Grand Junction web page, accessed September 1, 2020, at https://www.gjcity.org/residents/street-systems/stormwater/.

Clary, J., Pitt, R., and Steets, B., 2014, Pathogens in urban stormwater systems: Urban Water Resources Research Council, 267 p., accessed March 11, 2020, at https:/ /collaborate.ewrinstitute.org/HigherLogic/System/ DownloadDocumentFile.ashx?DocumentFileKey= c468710e-971d-4284-a052-0efae9e25d3d\&forceDialog=0.

Colorado Department of Public Health and Environment [CDPHE], 2016, Water Quality Control Commission regulation \#93-Colorado's Section 303(d) list of impaired waters and monitoring and evaluation list: Colorado Department of Public Health and Environment, 5 CCR 1002-93, 142 p., accessed October 17, 2019, at https://www.colorado.gov/ pacific/sites/default/files/93_2016(11).pdf.
Colorado Department of Public Health and Environment [CDPHE], 2020, Regulation no. 31, the basic standards and methodologies for surface water: Colorado Department of Public Health and Environment web page, accessed February 5, 2020, at https://www.sos.state.co.us/CCR/ GenerateRulePdf.do? ruleVersionId $=7455 \&$ fileName $=5 \% 20$ CCR\%201002-31.

Crawford, C.G., 2004, Sampling strategies for estimating acute and chronic exposures of pesticides in streams: Journal of American Water Resources Association, 489 p.

Duke, H.R., Kruse, E.G., Olsen, S.R., Champion, D.F., and Kincaid, D.C., 1976, Irrigation return flow water quality as affected by irrigation water management in the Grand Valley of Colorado: Fort Collins, Colo., U.S. Department of Agriculture, $123 \mathrm{p}$.

Gidley, R.G., Miller, L.D., and Day, N.K., 2020, Analysis of Escherichia coli, total recoverable iron, and dissolved selenium concentrations and loads for selected 303(d) listed segments in the Grand Valley, western Colorado, 1980-2018 (ver. 3.0, August 2021): U.S. Geological Survey, https://doi.org/10.5066/P9P6WI44.

Hem, J.D., 1985, Study and interpretation of the chemical characteristics of natural water: U.S. Geological Survey Water-Supply Paper 2254. 3rd ed., 263 p.

Henneberg, M.F., 2016, 2014 annual summary of the Lower Gunnison River Basin Selenium Management Program water-quality monitoring, Colorado: U.S. Geological Survey Open-File Report 2016-1129, 25 p., accessed March 5, 2020, at https://doi.org/10.3133/ofr20161129.

Hirsch, R.M., Archfield, S.A., and De Cicco, L.A., 2015, A bootstrap method for estimating uncertainty of water quality trends: Environmental Modelling \& Software, v. 73, p. 148-166. [Also available at https://doi.org/10.1016/ j.envsoft.2015.07.017.]

Hirsch, R.M., and De Cicco, Laura, 2015, User guide to exploration and graphic for RivEr Trends (EGRET) and dataRetrieval $-\mathrm{R}$ packages for hydrologic data: U.S. Geological Survey Techniques and Methods, book 4, chap. A10, 95 p., [Also available at https://doi.org/ 10.3133/tm4A10.]

Hirsch, R.M., Moyer, D.L., and Archfield, S.A., 2010, Weighted regressions on time, discharge, and season (WRTDS), with an application to Chesapeake Bay river inputs: Journal of the American Water Resources Association, v. 46, no. 5, p. 857-880. [Also available at https://doi.org/10.1111/j.1752-1688.2010.00482.x.] 
Kircher, J.E., Dinicola, R.S., and Middelburg, R.M., 1984, Trend analysis of salt load and evaluation of the frequency of water-quality measurements for the Gunnison, the Colorado, and the Dolores Rivers in Colorado and Utah: U.S. Geological Survey Water-Resources Investigations Report 84-4048, 69 p., accessed April 28, 2020, at https://doi.org/10.3133/wri844048.

Köppen, W., 1918, Klassification der Klimate nach Temperatur, Niederschlag and Jahreslauf: Petermanns Geographische Mitteilungen, v. 64, p. 193-203, 243-248.

Larson, S.J., Crawford, C.G., and Gilliom, R.J., 2004, Development and application of watershed regressions for pesticides (WARP) for estimating atrazine concentration distributions in streams: U.S. Geological Survey WaterResources Investigations Report 03-4047, 15 p.

Leonard, N., 2020, The IDEXX water testing solutions blogWhat's the difference between MPN and CFU?: Westbrook, Maine, IDEXX Laboratories, Inc., accessed February 12, 2020, at https://www.idexx.com/en/blogs/idexx-watertesting-solutions/what-s-the-difference-between-mpnand-cfu/.

Leib, K.J., 2008, Concentrations and loads of selenium in selected tributaries to the Colorado River in the Grand Valley, western Colorado, 2004-2006: U.S. Geological Survey Scientific Investigations Report 2008-5036, 36 p., https://pubs.usgs.gov/sir/2008/5036/.

Lin, Z.-Q., Cervinka, V., Pickering, I.J., Zayed, A., and Terry, N., 2002, Managing selenium-contaminated agricultural drainage water by the integrated on-farm drainage management system - Role of selenium volatilization: Water Research, v. 36, no. 12, p. 3150-3160. https://doi.org/ 10.1016/S0043-1354(02)00007-6.

MAPLOGS.COM, 2021, Worldwide elevation map finder, accessed February 24, 2021, at https://elevation.maplogs.com/.

Mayo, J.W., 2008, Estimating the effects of conversion of agricultural land to urban land on deep percolation of irrigation water in the Grand Valley, western Colorado: U.S. Geological Survey Scientific Investigations Report 2008-5086, 58 p. [Also available at https://doi.org/10.3133/sir20085086.]

Mayo, J.W., and Leib, K.J., 2012, Flow-adjusted trends in dissolved selenium load and concentration in the Gunnison and Colorado Rivers near Grand Junction, Colorado, water years 1986-2008: U.S. Geological Survey Scientific Investigations Report 2012-5088, 33 p. [Also available at https://doi.org/10.3133/sir20125088.]
McBee, A., Guccini, W., and Knight, R., 2011, Monitoring and evaluation report, Grand Valley Unit, Colorado River Salinity Control Project: U.S. Department of Agriculture, Natural Resources Conservation Service, 25 p., accessed March 12, 2020, at https://www.nrcs.usda.gov/Internet/ FSE_DOCUMENTS/nrcs144p2_061114.pdf

Mesa County, 2020, Drainage system maintenance: Mesa County web page, accessed September 1, 2020, at https:// www.mesacounty.us/publicworks/floodplain-management/ drainage-system-maintenance/.

Miller, L.D., and Stogner, R.W., Sr., 2017, Characterization of water quality and suspended sediment during cold-season flows, warm-season flows, and stormflows in the Fountain and Monument Creek watersheds, Colorado, 2007-2015: U.S. Geological Survey Scientific Investigations Report 2017-5084, 47 p., accessed March 11, 2020, at https://doi.org/10.3133/sir20175084.

National Oceanic and Atmospheric Administration, National Centers for Environmental Information, 2019, Data tools - 1981-2010 normals: National Oceanic and Atmospheric Administration, National Centers for Environmental Information dataset accessed August 20, 2019 at https://www.ncdc.noaa.gov/cdo-web/datatools/normals.

National Water Quality Monitoring Council, 2019, Water quality portal: National Water Quality Monitoring Council, accessed December 3, 2019, at https://www. waterqualitydata.us/.

R Core Team, 2019, R-A language and environment for statistical computing: Vienna, Austria, R Foundation for Statistical Computing, accessed July 2019, at https://www.R-project.org/.

Rare Earth Science, L.L.C., 2017, Environmental assessment - GVIC canal lining phase IV—540 project, Mesa County, Colorado: Paonia, Colo., U.S. Bureau of Reclamation and Grand Valley Irrigation Company, accessed March 11, 2020, at https://www.usbr.gov/uc/ envdocs/ea/pdf/GVICCanalLiningFinalEA.pdf.

Richards, R.J., and Moore, J.L., 2015, Characterization of streamflow, salinity, and selenium loading and land-use change in Montrose Arroyo, western Colorado, from 1992 to 2013: U.S. Geological Survey Scientific Investigations Report 2015-5039, 18 p., accessed March 5, 2020, at https://doi.org/10.3133/sir20155039.

Runkel, R.L., Crawford, C.G., and Cohn, T.A., 2004, Load Estimator (LOADEST): A FORTRAN Program for estimating constituent loads in streams and rivers: U.S. Geological Survey Techniques and Methods Book 4, Chapter A5, 69 p., https://pubs.usgs.gov/tm/2005/tm4A5/. 
Searcy, J.K., 1959, Flow-duration curves, manual of hydrology-part 2, Low-flow techniques: U.S. Geological Survey Water-Supply Paper 1542-A, 33 p.

Seiler, R.L., Skorupa, J.P., Naftz, D.L., and Nolan, B.T., 2003, Irrigation-induced contamination of water, sediment, and biota in the western United States-synthesis of data from the National Irrigation Water Quality Program: U.S. Geological Survey Professional paper 1655, 123 p. [Also available at https://doi.org/10.3133/pp1655.]

Shamberger, R.J., 1981, Selenium in the environment: The Science of the Total Environment, v. 17, no. 1, p. 59-74. [Also available at https://doi.org/10.1016/00489697(81)90108-X.]

Shipp, A., and Cordy, G.E., 2002, The USGS Role in TMDL Assessments: U.S. Geological Survey Fact Sheet 130-01, 4 p. [Also available at https://doi.org/10.3133/fs13001.]

Simonds, W.J., 1994, Grand Valley project: Bureau of Reclamation, accessed August 20, 2019 at https://www.usbr.gov/ projects/pdf.php?id=122.

Stetson, S.J., Mendez, D., Harris, C., and Kanagy, C., 2019, Characterization of bias and variability in dissolved trace elements determined by inductively coupled plasma-mass spectrometry ( $\mathrm{ICP}$ - MS) attributable to a deviation in the acid concentration of calibration standards during a period starting no earlier than October 2005 and as late as 2008, and ending August 8, 2015: U.S. Geological Survey National Water Quality Laboratory Technical Memorandum 2019.01, 15 p. [Also available at https://nwql.usgs.gov/ tech_memos/Acid\%20Matrix\%20study $\% 20$ tech $\%$ 20memo.pdf.]

Thomas, J.C., Leib, K.J., and Mayo, J.W., 2008, Analysis of dissolved selenium loading for selected sites in the Lower Gunnison River Basin, Colorado, 1978-2005: U.S. Geological Survey Scientific Investigations Report 2007-5287, 25 p. [Also available at https://doi.org/10.3133/ sir20075287.]

Thomas, J.C., McMahon, P.B., and Arnold, L.R., 2019, Groundwater quality and hydrology with emphasis on selenium mobilization and transport in the Lower Gunnison River Basin, Colorado, 2012-16: U.S. Geological Survey Scientific Investigations Report 2019-5029, 69 p., accessed March 5, 2020, at https://doi.org/10.3133/sir20195029.

U.S. Environmental Protection Agency, [EPA], 2020, Clean Water Act Section 303(d)-Impaired Waters and Total Maximum Daily Loads (TMDLs): U.S. Environmental Protection Agency, accessed April 27, 2020 at https://www.epa.gov/tmdl.
U.S. Geological Survey, 2019, USGS water data for the nation: U.S. Geological Survey National Water Information System database, accessed September 23, 2019, at https://doi.org/10.5066/F7P55KJN.

Walker, R., 2014, Water quality in the Upper Crystal River and Coal Creek Basin: Basalt, Colo., Roaring Fork Conservancy, 103 p., accessed March 11, 2020, at http://www.roaringfork.org/media/1577/crystal-wq-reportfinal-2617.pdf.

Williams, C.A., Moore, J.L., and Richards, R.J., 2011, Assessment of surface-water quantity and quality, Eagle River watershed, Colorado, 1947-2007: U.S. Geological Survey, Scientific Investigation Report 2011-5075, 139 p., accessed March 11, 2020, at https://doi.org/10.3133/ sir20115075. 

Denver Publishing Service Center

For more information concerning the research in this report, contact the

Director, USGS Colorado Water Science Center

Box 25046, Mail Stop 415

Denver, CO 80225

(303) 236-4882

Or visit the Colorado Water Science Center website at https://www.usgs.gov/centers/co-water 


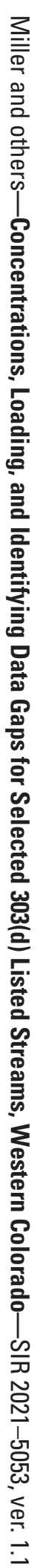

